\title{
AN ANALYSIS OF THE SECURITIES ACTS AMENDMENTS OF 1964 ${ }^{\dagger}$
}

\author{
Richard M. Phillips* and Morgan Shipman**
}

I

INTRODUCTION

I HE Securities Acts Amendments of $1964^{1}$ (Amendments Act) legislation since the enactment of the Investment Company Act of $1940^{2}$ (Investment Company Act) and the Investment Advisers Act of $1940^{3}$ (Advisers Act). The new legislation amends only the Securities Exchange Act of 1934* (Exchange Act), with the exception of one limited amendment to the Securities Act of 19335 (Securities Act).

The Amendments Act may be divided into two parts, the first dealing primarily with issuers of securities. The main feature of this portion is an extension of the registration, periodic reporting, proxy and insider trading provisions of sections 12, 13, 14 and 16 of the Exchange Act to larger over-the-counter companies. These provisions were formerly applicable only to listed companies. In addi-

FOR a table OF SECTION TITLES IN THIS ARTICLE, SEE THE TABle OF Contents precedinc PAGE 667 . THE COMPLETE CITATION TO SHORT CITATION FORMS USED IN THE FOOTNOTES MAY BE FOUND IN NOTES $1,6,7,15 \& 70$.

$\dagger$ The Securities and Exchange Commission, as a matter of policy, disclaims responsibility for any private publication by any of its members or cmployees. Therefore, the views expressed herein do not necessarily reflect the views of the Commission or its staff. In general, this article speaks as of late September, 1964, although some subsequent developments are noted.

- Special Counsel, Office of General Counsel, Securities and Exchange Commission; Member, District of Columbia and New York Bars.

* Special Counsel, Office of Program Planning, Securities and Exchange Commission; Member, District of Columbia and Texas Bars.

I Pub. L. No. 467, 88th Cong., 2d Sess. (Aug. 20, 1964).

For an excellent survey of the Amendments Act, see CCH FED. SEC. L. REP., SEcurITIEs ACTS AMENDMENTS of 1964 wITH Explanition (Aug. 7, 1964) [hereinafter cited as CCH SPECIAL]

254 Stat. 789 (1940), as amended, 15 U.S.C. $\$ \S 80 \mathrm{a}-1$ to -52 (1958), as amended, 15 U.S.C. $\$ \S 80 \mathrm{a}-2$ to -39 (Supp. V, 1964).

${ }^{3} 54$ Stat. 847 (1940), as amended, 15 U.S.C. $\$ \S 80 \mathrm{~b}-1$ to -21 (1958), as amended, 15 U.S.C. $\$ \S 80 \mathrm{~b}-2$ to $-18 \mathrm{a}$ (Supp. V, 1964).

448 Stat. 881 (1934), as amended, 15 U.S.C. $\$ \$ 78$ a to hh-I (1958), as amended, 15 U.S.C. $\$ \S 78 c$-s (Supp. V, 1964).

548 Stat. 74 (1933), as amended, 15 U.S.C. $\$ \S 77 \mathrm{a}$-aa (1958), as amended, 15 U.S.C. $\S \S 77 \mathrm{~b} \cdot \mathrm{h}$ (Supp. V, 1964). 
tion, major changes made in sections $12,13,14,15$ (c) and 15 (d) of the Exchange Act are applicable to over-the-counter companies, as well as other issuers. The second part of the act deals primarily with broker-dealers in securities and their personnel. It imposes upon such persons increased qualifications standards, as well as strengthened and refined administrative disciplinary controls. The following introductory paragraphs briefly recount the extensive legislative history of the Amendments Act. Following that discussion, the two parts of the Amendments Act are analyzed separately.

Although several proposals similar to portions of the Amendments Act had been considered previously by Congress, ${ }^{6}$ the impetus necessary for passage of the new legislation was provided by the $R e$ port of Special Study of Securities Markets ${ }^{7}$ (Special Study). Most of the provisions of the Amendments Act were recommended (though in some instances in different form) and discussed in the first segment of the Special Study, released on April 3, 1963.8 On the same day, the Securities and Exchange Commission (Commission) invited leading securities industry groups to organize a liaison committee to work with the Commission in drafting a bill to effectuate the more important legislative recommendations contained in the first segment of the Special Study. ${ }^{9}$

On April 19, 1963, the Commission submitted a draft of its proposed legislative program to the industry liaison group. ${ }^{10}$ That draft, which was closely geared to the Special Study recommendations, is reprinted in the House hearings. ${ }^{11}$ Until late May, the Com-

'These earlier proposals would have extended $\S \S 12,13,14$ and 16 of the Exchange Act in much the same fashion as did the Amendments Act. See text accompanying notes, 38-48, infra; 2 Loss, Securities Regulatron ch. 6E (2d cd. 1961) [hereinafter cited as Loss]; S. REP. No. 379, 88th Cong., 1st Sess. 14-19 (1963) [hereinafter cited as SENAte REPORT].

Proposals similar to several of the other provisions of the Amendments Act were submitted by the Commission in 1941, 1956, 1957 and 1959. See 1 Loss 198-99, 205 n.80.

'Securities and Exch. Comm'n, Report of Special Study of Securities Market, H.R. Doc. No. 95, 88th Cong., 1st Sess. (1963) [hereinafter cited as Special Study]. For a brief discussion of the Special Study and its history, see Cary, The Special Study of Securities Markets of the Securities and Exchange Commission, 62 Mrch. L. REv. 557 (1964). The Commission's position on various recommendations of the Special Study is reflected in in Hearings Before a Subcommittee of the House Committee on Interstate and Foreign Commerce on H.R. 6789, H.R. 6793, and S. 1642, 88th Cong., 1st \& 2d Sess., pt. 1, at 27-43 (1963-1964) [hereinafter cited as House Hearings].

${ }^{8}$ Sec House Hearings, pt. 1, at 1-23, 156.

${ }^{\circ} I d$. at 650 . For the liaison group's reply, see $i d$. at 651 .

${ }^{10} I d$. at 656 .

${ }^{11} I d$. at 656 . 
mission received comments from the liaison committee on successive redrafts. In light of these comments, the Commission's own reconsiderations, and suggestions from other governmental agencies, many of the proposals were altered and refined.12

On June 3, 1963, the Commission submitted its legislative proposals and a general explanatory statement to Senator Robertson, Chairman of the Senate Banking and Currency Committee (Senate Committee), and to Representative Harris, Chairman of the House Committee on Interstate and Foreign Commerce (House Committee). ${ }^{13}$ The bills, S. 1642, H.R. 6789, and H.R. 6793, were introduced on the following day. ${ }^{14}$ At that point the bills were identical, and reflected verbatim the Commission's recommendations.

Hearings (Senate hearings) were held in late June before the Subcommittee on Securities (Senate Subcommittee) of the Senate Committee.15 The Senate Subcommittee approved S. 1642 on July $9,1963,{ }^{16}$ and the Senate Committee approved the bill in executive session one week later..17 S. 1642 was formally reported on July 24, $1963 .^{18}$ The Senate Subcommittee had adopted one major alteration relating to banks, ${ }^{10}$ and although numerous editorial, clarifying, and technical changes were made, ${ }^{20}$ neither the Subcommittee nor the Committee proposed any other substantial changes. S. 1642 was passed by the Senate in its reported form on July 30 , $1963 .{ }^{21}$

\footnotetext{
12 See id. at 646-69.

13109 Cong. Rec. 9963-69 (1963).

14 Id. at 9946, 9963, 10175.

${ }^{15}$ In the hearings before the Senate Subcommittee, the Commission submitted for the record a technical statement and separate "justifications" for each part of the Amendments Act. Hearings Before a Subcommittee of the Senate Committee on Banking and Currency on S. I642, 88th Cong., 1st Scss. 352, 384, 388 (1963) [hercinafter cited as Senate Hearings]. In addition, Chairman Cary's statement was reprinted. Id. at 49. Moreover, the Commission supplied several memoranda and letters found in the Senate hearings and the Senate Report. Though there is considerable overlap between the four Commission statements, each contains some material found nowhere else.

${ }^{10}$ N.Y. Times, July 10, 1963, p. 43, col. 4; Wall Street Journal, July 10, 1963, p. 4, col. 2. col. 6 .

${ }^{17}$ N. Y. Times, July 17, 1963, p. 37, col. 1; Wall Street Journal, July 17, 1963, p. 20,

18 See Senate Report.

${ }^{10}$ See sources cited notes $16-18$ supra.

${ }^{20}$ See Senate Report 54-56; Senate Hearings 260-64, 278-81.

2109 CONG. REC. 13715-29 (1963). In a few instances the section-by-section summary inserted in the record appears to refer to the provisions of S. 1642 as introduced rather than as reported.
} 
The Subcommittee on Commerce and Finance (House Subcommittee) of the House Committee commenced hearings (House hearings) on all three bills on November 19, 1963.22 These hearings continued intermittently for three months, covering many matters in addition to the bills, ${ }^{23}$ and comprehensive written statements were again submitted by the Commission. ${ }^{24}$ During the third week of March, 1964, the House Subcommittee approved tentative action on H.R. 6793 in executive session. ${ }^{25}$ On March 25, the Subcommittee took final action, and this bill was reported to the full House Committee. ${ }^{26}$ Final action by the Subcommittee included several major amendments to H.R. 6793 and the incorporation of many minor changes made by the Senate Committee in S. 1642. When the House Committee considered H.R. 6793 in executive session on May 6 and 7 , it inserted several substantive, technical and stylistic changes, as well as adopting further minor changes included by the Senate Com-

\footnotetext{
22 See House Hearings.

${ }^{23}$ During this period the New York, American, and Midwest Stock Exchanges and the Investment Bankers Association submitted long position papers regarding the Special Study's recommendations. Chairman Cary of the Commission, in both of his appearances, reported on the progress of the Commission and the self-regulatory bodies in implementing the Special Study. See also 110 Cong. REc. 20136-38 (daily ed. Aug. 21, 1964). Matters of financial responsibility, triggered by the insolvencies of two New York Stock Exchange member firms in November, 1963, and specialists' performance were extensively covered in the second appearances of the Commission and the New York Stock Exchange in February, 1964. See House Hearings, pt. 2, at 946-67 (Commission's report on specialists' performance). See also id. at 1200-02 (Commission's position on Blau v. Lehman, 368 U.S. 403 (1962)); Senate Hearings 262-63.

The reasons for incorporating or excluding provisions of the Commission's 1959 legislative program were considered during the House hearings. House Hearings, pt. 1, at 320-28. The Commission's role in establishing accounting practices and the Subcommittee's consideration of areas in which materially different results would be produced by alternative practices are also extensively documented. Id., pt. 2, at 756-61, 1296-347.

During the appearance of the National Association of Securities Dealers, Inc. (NASD), there was a comprehensive discussion relating to the issue of whether the over-the-counter market should remain decentralized and unautomated. In addition, the action of the Commission regarding applications for appointment of receivers for broker-dealers was discussed. Id., pt. 1, at 317-20. Over-the-counter trading of listed securities was also considered. Id. at $396,413-15$.

2I In the Commission's first appearance before the House Subcommittee, its statements before the Senate Subcommittee were revised and placed in the record. See note 15 supra. In the Commission's second appearance additional prepared statements, letters and memoranda relating to the bills were placed in the record.

${ }^{25}$ For fragmentary reports, see N.Y. Times, March 21, 1964, p. 29, col. 3; N.Y. Times, March 20, 1964, p. 45, col. 4; Wall Street Journal, March 20, 1964, p. 32, col. 2.

${ }^{20}$ N.Y. Times, March 26, 1964, p. 49, col. 2; Wall Street Journal, March 26, 1964, p. 2, col. 3. The Times report that the House Subcommittee had adopted an exemption from required membership for direct sellers of mutual fund shares was erroneous.
} 
mittee in S. 1642.27 H.R. 6793 was formally reported by the House Committee on May 19, 1964..28

After discussing the bill for two days, the House passed H.R. 6793, as reported, on August 5, 1964. ${ }^{29}$ Immediately thereafter, the House discharged the House Committee from consideration of S. 1642, removed all language after the enacting clause of that bill, and substituted therefor the language of H.R. 6793 as passed. When S. 1642 was passed as so amended, the House laid H.R. 6793 on the table..$^{30}$

Senator Robertson then requested and received the Commission's comments on the House changes. ${ }^{31}$ On August 6, the Senate agreed to the House amendment to S. 1642.32 The Amendments Act was sigued by President Johnson on August 20, 1964. ${ }^{33}$

\section{II}

Extending, ENForcing ANd Improving THE Disclosure REQUIREMENTS

Part II of this article deals primarily with the provisions of the Amendments Act affecting obligations of issuers of both listed and over-the-counter securities. The most important of these provisions will ultimately extend the registration, periodic reporting, proxy solicitation, and insider trading provisions of sections 12, 13, 14 and 16 of the Exchange Act to an estimated 3,500 issuers of overthe-counter securities.

Section A of this part discusses the background of this legislation and outlines the amended disclosure and insider trading requirements of the Exchange Act and Commission rules thereunder. It also discusses the new provision transferring from the Commission to the federal bank regulatory agencies the jurisdiction to administer much of the Exchange Act with respect to bank securities, and

${ }^{27}$ N.Y. Times, May 8, 1964, p. 43, col. 1; Wall Street Journal, May 8, 1964, p. 3, col. 1 (slightly inaccurate in its description of the provisions on banks and insurance companies).

${ }_{28}^{28}$ N.Y. Times, May 20, 1964, p. 59, col. 1.

29110 Cong. REc. 17320-33, 17596-609 (daily ed. Aug. 4 \& 5, 1964).

${ }^{30} 110$ CoNG. Rec. 17605-09 (daily ed. Aug. 5, 1964).

${ }^{31}$ Id. at $17535-37$.

32110 ConG. REc. 17793-805 (daily ed. Aug. 6, 1964).

${ }^{33}$ President Johnson reccived the Amendments Act on August 10. 110 Covg. REc. 18166 (daily ed. Aug. 10, 1964). The remarks of Chairman Harris and President Johnson upon the signing of the act are found in 110 CoNG. REc. 20136.38 (daily ed. Aug. 21, 1964). 
analyzes the coverage criteria for registration of over-the-counter securities. In addition, there is discussion of the exemptions for such securities, with particular emphasis on those for securities of insurance companies, foreign and inactively traded securities. Lastly, it discusses the conditions for termination of registration, the amendments to section $12(\mathfrak{f})$ governing unlisted trading privileges on exchanges, and new section 16 (d), which provides a limited exemption from sections $16(\mathrm{~b})$ and $16(\mathrm{c})$ for transactions of broker-dealers which are incident to the establishment or maintenance of an overthe-counter market. These provisions affect not only over-thecounter issuers, but also issuers of securities registered and listed for trading on exchanges which have a class of unlisted securities that meets the coverage criteria contained in the Amendments Act.

Section $B$ deals with the provisions of the Amendments Act affecting the Commission's enforcement powers against issuers, their managements and their securities. It contains a discussion. of the Commission's power, under new section 15 (c) (4), to issue an order compelling compliance with requirements of the act, the Commission's power, under new section 15 (c) (5), summarily to suspend over-the-counter trading in securities for periods of ten days, and the changes in sections 20 (c) and 32 (b).

Section $C$ deals with those provisions of the Amendments Act designed to strengthen and to close gaps in the disclosure requirements of the Exchange Act (which are now applicable to both issuers of listed and unlisted securities) and the Securities Act. It discusses the amendments to sections 12 and 13 relating to disclosures of material contracts, the amendment to section 14 (b) making effective the Commission's rulemaking power to require transmission of proxy solicitation material with respect to securities held in street name by broker-dealers, and new section 14 (c), which empowers the Commission to require that information, equivalent to that which would be contained in a proxy statement, be sent to shareholders when no proxies are solicited. In addition, changes in section 15 (d) relating to the filing of reports by issuers of securities offered pursuant to an. effective Securities Act registration statement, and changes in the prospectus delivery requirements of sections 4 and 5 of the Securities Act are analyzed. 


\section{A. Extension of Disclosure Requirements to Over-the-Counter Securities}

\section{Background}

It is frequently said that disclosure is "the keystone" of the federal securities laws. ${ }^{34}$ These laws are predicated on the principle that fair and honest securities markets can best be maintained when securities are bought and sold on the basis of complete and accurate financial and other information material to informed investment decisions. To this end, the Securities Act imposes extensive disclosure requirements on issuers, their controlling persons and underwriters engaged in the public distribution of securities..$^{35}$ A comprehensive pattern of disclosure requirements for issuers of securities and their insiders has also been established through the Exchange Act. These are found in the registration and periodic reporting requirements of sections 12 and 13 and the proxy solicitation and insider trading provisions of sections 14 and 16. These disclosure requirements are of benefit to investors in deciding whether to buy, sell, or hold outstanding securities. Thus, they are of primary importance in the trading markets, thereby complementing the Securities Act requirements. The disclosure requirements of both acts serve another highly important function; by subjecting corporate management to the glare of publicity, they provide significant controls over, and inevitably reduce, conflicts of interest and undesirable management practices. ${ }^{36}$

Prior to the Amendments Act, sections 12, 13, 14 and 16 were generally applicable to issuers which had voluntarily listed and registered securities for trading on a national securities exchange, and only applied to over-the-counter securities on a fragmentary basis. Some over-the-counter issuers which had filed registration statements under the Securities Act were required by section 15 (d) of the Exchange Act to comply with the periodic reporting re-

${ }^{84}$ Special Study, pt. 3, at 1.

${ }^{25}$ For a detailed discussion of the Securities Act, see 1 Loss, chs. $2 \& 3$. For a comprehensive survey of the controls over security distributions under all of the federal securities laws, see Cohen, Federal Legislation Affecting the Public Offering of Securities, 28 GEO. WASH. L. REv. 119 (1959).

${ }^{30}$ See Cohen \&: Phillips, Conflicts of Interest and the Federal Secturities Latus, 24 FED. B.J. 321 (1964). For an excellent discussion of the impact of disclosure requirements on business ethics, sec Cary, Corporate Standards and Legal Rules, 50 CALIF. L. REv. 408 (1962). 
quirements of section 13. However, only investors in public utility holding companies registered under the Public Utility Holding Company Act of 1935 $5^{37}$ (Holding Company Act), and in investment companies registered under the Investment Company Act were afforded protections comparable to those provided investors in listed securities. The Amendments Act ultimately will extend these disclosure requirements, subject to certain exemptions, to all over-thecounter issuers having total assets of more than one million dollars and a class of equity security held of record by 500 or more persons.

This extension is the culmination of thirty years of legislative effort to eliminate a disparity in investor protection which even the Congress that enacted the Exchange Act in 1934 never felt was justified. At that time the over-the-counter market was far less important than it is today, and little information was available concerning its mechanisms or the securities traded there. ${ }^{38}$ Moreover, in 1934, there was a serious constitutional question whether Congress, under the federal commerce power, could apply disclosure requirements directly to over-the-counter issuers, which, unlike issuers of listed securities, do not directly control the initiation of the trading market for their securities. However, to forestall evasion of federal regulation by the delisting of exchange-traded securities, ${ }^{39}$ section 15 of the original Exchange Act ${ }^{40}$ prohibited brokers and dealers from creating a market in securities in contravention of such rules as the Commission might adopt to "insure" investors in over-the-counter securities "protection comparable" to that provided investors in listed securities.

The Commission soon concluded that section 15 was unworkable because it imposed sanctions on brokers and dealers, who were not in a position to furnish information concerning issuers and their securities, rather than directly on issuers and their managements. ${ }^{41}$ At the Commission's request, Congress in 1936 replaced the original section 15 with section 15 (d), which required issuers filing a registration statement under the Securities Act to execute undertakings to comply with the reporting requirements-but not the proxy solicitation or insider trading provisions-of the Exchange Act under

\footnotetext{
${ }^{37} 49$ Stat. 838 (1935), as amended, 15 U.S.C. $\$ \$ 79$ to $79 z-6$ (1958).

${ }^{38}$ See 2 Loss 1150-51.

30 S. Rep. No. 792, 73d Cong., 2d Sess. 6 (1934).

1048 Stat. 895 (1934).

"ISE, Report on Trading in Unlisted Securities Upon Exchanges 17-21 (1936).
} 
specified conditions. ${ }^{42}$ A Commission proposal in 1941 to broaden the application of section 15 (d) was never acted upon by the Congress. ${ }^{43}$

In 1946, the Commission for the first time proposed that overthe-counter issuers be required to register their securities in the same manner as issuers of listed securities, and that sections 19, 14 and 16 of the Exchange Act be extended to all over-the-counter securities required to be registered.44 Although several bills implementing this proposal were introduced in the Congress during the late 1940's and early 1950 's, ${ }^{45}$ significant interest was not created until a majority of the Senate Committee, following a comprehensive study of the securities markets, announced support for the principle of equal protection for investors in over-the-counter securities. ${ }^{40}$ In 1955, 1956 and 1957, the Senate Committee held hearings on bills embodying various coverage criteria and exemptions. ${ }^{47}$ Although in 1957 the Committee did report a bill limited to companies having ten million

$\$ 2$ Section 6 (d) of the Amendments Act has revised $\$ 15$ (d) to eliminate the requirement for undertakings by issuers filing Securities Act registration statements after August 20, 1964, and to impose a duty to file reports for the fiscal year in which the statement becomes effective and for any subsequent fiscal year on the first day of which the securities to which the statement relates are held of record by 300 or more persons. Issuers filing registration statements on or before August 20, 1964, will continuc to file reports in accordance with the terms of their undertaking, but may be relievcd of the duty to file in the same manner as issuers filing statements after that datc.

is House Comm. on Interstate and Foreign Commerce, 77th Conc,, 1st Sess., SEC Report on Proposals for Amendients to the Securities Act of 1933 and the Securities Exchange Act of 1934, 23 (Comm. Print 1941).

4SEC, Proposal to Safeguard Investors in Unregistercd Securities, H.R. Doc. No. 672, 79th Cong., 2d Sess. 31-32 (1946).

${ }_{15}$ H.R. 7955, 82d Cong., 2d Sess. (1952); H.R. 1383 \& 4143, 82d Cong., 1st Sess, (1951); S. 1860, 82d Cong,, 1st Sess. (1951) (reprinted, Senate Hearings 462); S. 2408, 81st Cong., 1st Sess. (1949) (reprinted, Senate Hearings 461); H.R. 7151, 79th Cong., 2d Sess. (1946). For an analysis of S. 2408, see Comment, The Frear Bill: Extension of Investor Protection to Unlisted Securities, 45 ILL. L. REv. 263 (1950).

${ }^{40}$ S. REp. No. 376, 84th Cong., 1st Sess. 9 (1955).

${ }_{17}$ S. 2054, 84th Cong., 1st Sess. (1955) (reprinted, Senate Fearings 464$)(\$ 5,000,000$ in assets and 500 security holders, with exemptions for issuers of excmpted securities as defined in $\$ 3$ (a) (12) of the Exchange Act, banks, charitable and other non-profit or * ganizations, and federally regulated or insured savings and loan type associations); S. 2054, 84th Cong., 1st Sess. (1955) (Comm. Print) $(\$ 2,000,000$ in assets and either 750 shareholders of record or debt issues of $\$ 1,000,000$ in principal amount if registered under the Securities Act, with exemptions for securities of insurance companies and securities excmpted in S. 2054 as originally introduced); S. 1168, 85th Cong., 1st Sess. (1957) (same coverage criteria and excmptions as proposed in amended S. 2054, with no exemption for insurance companies). See Hearings Before a Subcommittee of the Senate Committee on Banking and Currency on S. 2054, 84th Cong, 1st \& 2d Sess. (1955-56); Hearings Before a Subcommittee of the Senate Committee on Banking and Currency on S. 594, S. 1168, and S. 1601, 85th Cong., 1st Sess. (1957). The House Committee had not 
dollars in assets and 1000 shareholders, ${ }^{48}$ even this limited measure failed to reach a vote in the Senate.

\section{Extended Disclosure Requirements}

Section 12 (b) of the Exchange Act requires, as a prerequisite to the listing and registration of a security on a national securities exchange, that the issuer of the security file an application for registration with both the exchange and the Commission. With effectiveness of registration, sections 13, 14 and 16 become applicable.

Under the Amendments Act new section 12 (g) follows the section 12 (b) pattern, except that under section $12(\mathrm{~g})$ registration is required for securities of issuers meeting the coverage criteria and is permitted for others, whereas under section 12 (b) the listing of securities is a voluntary act by the issuer. Section $12(\mathrm{~g})$ requires that over-the-counter issuers file a registration statement similar to a section 12 (b) application with the Commission within 120 days after the last day of their first fiscal year after the effective date of the section-July 1, 1964-on which they have total assets in excess of one million dollars and a class of non-exempt equity securities held of record by 750 or more persons. As under section $12(\mathrm{~b})$, and as explained in more detail below, registration under section 12 (g) also makes sections 13,14 and 16 applicable. Like section 12 (b) and unlike section $15(\mathrm{~d})$, section $12(\mathrm{~g})$ is in no way dependent upon whether the issuer has ever filed a Securities Act registration statement. Indeed, the section is applicable to several classes of issuers whose securities are exempted from Securities Act registration requirements.

Since the effective date of section $12(\mathrm{~g})(1)$ preceded the enactment of the bill, some section 12 (g) filings could become due as early as November, 1964. However, the Commission, acting pursuant to its authority under section 12 (g) (1) to postpone the dates for filing registration statements, has extended the filing date to

held hearings on bills to extend $\$ \S 12,13,14$ and 16 to over-the-counter securities prior to the introduction of H.R. 6789 and H.R. 6793 in the 88th Congress.

4 The reported bill, an amended version of S. 1168, deleted registration for debt securities and provided additional exemptions for securities of state supervised insurance companies, savings and loan type associations, trust companies not accepting deposits, and dealers in bankers' and trade acceptances. See S. REP. No. 700, 85th Cong., lst Sess. (1957). For more detailed histories of prior legislative efforts, see SENATE REPORT 14-19; 2 LOss 1149-64; Note, The Fulbright Bill: Extension of Investor Protection to Unlisted Securities, 7 I HARv. L. REv. 1337 (1958). 
April 30, 1965, for all companies which are not required to file periodic reports with the Commission under section 13 or 15 (d) at the time the registration statement otherwise is required to be filed. ${ }^{40}$ This extension will provide companies not presently subject to Exchange Act disclosure requirements additional time to prepare for registration.

Under section $12(\mathrm{~g})(\mathrm{l})$ registration for classes of an equity security held of record by less than 750 persons initially will not be required. After July 1, 1966, the test will be 500 or more persons.

Section $12(\mathrm{~g})(1)$ also permits voluntary registration of classes of equity securities not required to be registered, whether or not the issuer has registered another class of securities. While voluntary registration by issuers not otherwise subject to section $12(\mathrm{~g})$ may be infrequent, it could occur if underwriters should require a commitment from issuers to register the securities being publicly offered, or if management, confronted with an impending proxy fight, should prefer that it be conducted under the umbrella of the Commission's proxy rules.

Section $12(\mathrm{~g})(1)$ requires the filing of a separate registration statement for each class of an issuer's securities meeting the coverage criteria. However, the Commission has adopted rules and regulations for the registration of exchange-traded securities under section 12 (b) which permit incorporation by reference of information contained in another application for registration under section 12 (b), and of financial statements and exhibits filed with the Commission by the same issuer under any of the federal securities laws. ${ }^{80}$ The Commission has indicated that it will follow similar procedures to reduce substantially duplication of filings by companies subject to section $12(\mathrm{~g})^{51}$

Section $12(\mathrm{~g})(1)$ provides that a registration statement shall contain such information and documents as the Commission specifies comparable to those required in an application to register securities for exchange trading under section 12 (b). The information required to be disclosed pursuant to section 12 (b) and Commission forms

\footnotetext{
'0 SEC Securities Exch. Act Rule 12g-1 (a), SEC Securities Exch. Act Release No. 7429, Sept. 15, 1964.

${ }^{\circ 0}$ SEC Securities Exch. Act Rule 12b-23, 17 C.F.R. \$ 240.12b-23 (1964); SEC Securities Exch. Act Rule 12b-32, 17 C.F.R. $\$ 240.12 b-32$ (1964); SEC Securities Exch. Act Rule 12b-35, 17 C.F.R. $\$ 240.12$ b-35 (1964).

${ }^{1}$ SEC Securities Exch. Act Release No. 7425, p. 5, Sept. 15, 1964. See also SENATt REPORT 61; Senate Hearings 354; House Hearings, pt. 1, at 214.
} 
thereunder ${ }^{52}$ consists of financial and other information material to a determination of the investment merits of a security. This includes relevant information and documents pertaining to: (1) the issuer's business; (2) its outstanding securities; (3) the identity and remuneration of its officers, directors and principal shareholders; (4) the interests of such persons in the securities of, and their material contracts and interests in transactions with, the issuer; (5) bonus and profit-sharing arrangements; (6) management and service contracts; (7) options which exist or are to be created in respect of the issuer's securities; and (8) balance sheets and profit and loss statements certified by independent public accountants. ${ }^{52 a}$

Section 12 (g) (l) expressly states that a registration statement shall become effective sixty days after filing or within such shorter time as the Commission may direct. ${ }^{53}$ Until the effective date a registration statement shall not be deemed filed for purposes of

52 The Commission has adopted ten different forms for registration under $\$ 12(\mathrm{~b})$. Form 10 is the basic form for use when no other form is specially applicable. The other forms, many of which are considerably modified from the basic form, are: Form 8-A for additional classes or series of securities when other securities of the issuer are registered on the exchange; form 8-B for securities to be registered upon the issuer's succession to one or more issuers of previously registered securities; Form 8-C for securities which are registered on another exchange; Form 14 for certificates of deposit issued by a committee; Form 16 for voting trust certificates and their underlying securities; Form 18 for securities of foreign governments and their political subdivisions; Form 19 for American Depositary Receipts and their underlying securities; Form 20 for non-bond securities of foreign private issuers, except those from North America and Cuba; Form 21 for bonds of foreign private issuers except bonds of North American and Cuban issuers which are not guaranteed by a foreign government. Although these forms generally are suitable for registration under $\S 12(\mathrm{~g})$, the Commission has not yet adopted or designated registration forms for $\S 12(\mathrm{~g})$ companies. It luas, however, proposed a revised Form $8-A$ as a summary registration form under $\S$ 12 (g) for issuers which have another class of security registered under $\S 12(\mathrm{~b})$ or $12(\mathrm{~g})$, and for issuers which have filed an effective Securities Act registration statement and (l) are subject to $\S 15$ (d) and have filed an annual report for the last fiscal year before the effective date of the $\$ 12$ (g) registration statement; or (2) the registration statement on Form 8 -A will become effective within one year after the end of the last fiscal year for which certified financials were included in a Securities Act registration statement or post effective amendment thereto; or (3) would be required to file reports under $\S 15$ (d) but for the fact that they have a security enjoying unlisted trading privileges on an exchange and have in fact filed an annual report pursuant to $\S 13$ for the last fiscal year ending before the effective date of the registration statement on Form 8-A. See SEC Securities Exch. Act Release No. 7447, Oct. 21, 1964.

52a Proposed Form 8-A, however, would require only a description of the securities to be registered, specimens or copies of such securities, and copies of the constituent instruments defining the rights of the holders of such instruments. SEC Securities Exch. Act Release No. 7447, Oet. 21, 1964.

os The Commission will not take action to shorten the sixty day period unless the issuer requests acceleration. House Hearings, pt. 1, at 214. See also SENATE REPORT 60. Cf. SEC Securities Exch. Act Rule 12d1-2, 17 C.F.R. $\$ 240.12$ d1-2 (1964). 
section 18 of the Exchange Act, which provides for express civil liabilities on behalf of those who rely upon false or misleading statements in material filed with the Commission pursuant to the act. Liabilities also might be incurred for violations of the antifraud provisions of section 10 (b) and Rule 10b-5 thereunder. In light of the weakening of the privity requirement, the initial statement, as well as other filings with the Commission, should be prepared with care. $^{54}$

It is not altogether clear whether sections $13,14,16(\mathrm{~b})$ and 16 (c) apply from the filing or from the effective date of the registration statement. The Amendments Act has altered these sections so that they now apply to "securities registered pursuant to section 12." Although section 12 (g) (1) states that an issuer shall "register [a] . . . security by filing with the Commission a registration statement," a security probably is not "registered" for purposes of sections 13, 14 and 16 until the effective date of the registration statement. Under section 12 (d) an application for exchange registration does not become effective, and sections 13, 14 and 16 do not become operative with respect to the securities covered by the application, until thirty days after the Commission has received a certification that the exchange has approved the application. This waiting period provides issuers and their insiders notice of the impending obligations they must assume by virtue of registration. The reference to separate filing and effective dates in section 12 (g) (1) would seem to serve a similar purpose, for it is difficult to find any other substantial reason for the careful distinction between the two dates made in section 12 (g) (1). Although the legislative history is largely silent on this point, the Commission's technical statement submitted to the Senate Subcommittee states unequivocally with respect to the proxy

${ }^{5}$ Section $10(\mathrm{~b})$ and Rule 10b-5 thereunder prohibit schemes to defraud, statements which are false or misleading, and acts, practices or courses of business which operate as a fraud in connection with the purchase or sale of a security by use of the mails or facilities of interstate commerce. Although neither $\$ 10$ (b) nor Rulc 10b.5 expressly provides for civil liabilities, the courts have consistently implied a private right of action on behalf of investors defrauded through violations of the rulc. Actions under $\S 10$ (b) are not necessarily subject to the limitations contained in $\$ 18$. In xecent cases courts have upheld $\S 10(\mathrm{~b})$ actions by investors who claimed reliance on allegedly false and misleading information disseminated by the defendant issuers in connection with purchases on the open market. Sec Freed v. Szabo Food Serv., CCH FED. SEc. L. REP. If 91317 (N.D. Ill. 1964); Miller v. Bargain City, U.S.A., 229 F. Supp. 33 (E.D. Pa. 1964). See generally 3 Loss 1757-805; North, Implied Liability Cases Under the Federal Securities Laws, 4 CoRp. Prac. Cosr. 1 (1962); Comment, The Prospects for Rule X-10B-5: An Emerging Remedy for Defrauded Investors, 59 YALE L.J. 1120 (1950). 
rules that: "An issuer of over-the-counter securities would become subject to section 14 (a) when its registration statement under section 12 (g) becomes effective." 55 The Commission has proposed to resolve the uncertainty by a rule providing that a class of securities for which a registration statement has been filed shall be deemed registered for purposes of sections $13,14,15$ (d) and 16 , only when the registration statement has become effective. $55 a$

Amendments to the registration statement do not delay effectiveness. If a statement is defective and is not amended, it would appear that the Commission would allow it to become effective in the defective form so as to trigger the applicability of sections 13 , 14 and 16. The Commission could then proceed administratively, under new section 15 (c) (4), or via the injunctive route, to require post-effective amendments to bring the statement up to par.

In any event, after "registration" section 13 of the Exchange Act will require issuers to keep reasonably current the information contained in the initial registration statement, and to file annual reports containing certified financial statements, ${ }^{56}$ semi-annual reports containing uncertified profit and loss and earned surplus statements, ${ }^{57}$ and current reports whenever important events of immediate interest to investors occur. ${ }^{58}$ In addition, certain real estate companies

¿Senate Hearings 357. Moreover, amended $\$ 16$ (a) provides for: (1) the filing of initial reports of equity security ownership by insiders of issuers with securities registered under $\S 12$ (g) by the effective date of the registration statement under that section, and (2) reports of changes in such ownership thereafter. The primary purpose of the reporting requirement is to provide information for purposes of the profit recovery provisions of $\S 16(\mathrm{~b})$. But the reports are not required for the period between the filing and effective dates, an anomalous result in terms of the effectiveness of $\$ 16(b)$ if a security is registered when the registration statement is filed.

Eca Proposed SEC Securities Exch. Act Rule 12b-6, SEC Securities Exch. Act Release No. 7459 , Nov. 12,1964 . The proposed rule appears to be drafted so as not to affect the possible application of $\$ \S 13,14$ and 16 to securities required to be registered but for which no registration statement is filed.

${ }^{\circ}$ Rule 13a-1 requires generally that the annual report be filed with the Commission within 120 days after the close of the fiscal year for each year following the last full fiscal year for which financial statements were filed in the application for registration. Form $10 . \mathrm{K}$ is the basic form for issuers which have filed a Form 10 application for registration. Other issuers use " $K$ " series forms corresponding to the number of the registration form they have filed.

${ }_{5 z}$ Rule 13a-13 requires most issuers which are required to file an annual report on Form $10 \cdot \mathrm{K}$ to file a semi-annual report on Form $9-\mathrm{K}$ within forty-five days after the end of the first half of each fiscal year.

${ }^{58}$ Rule 13a-11 requires most issuers of registered securities to file a current report on Form 8-K within ten days after the close of any month during which any event specified in the form occurs. These events include changes in control; material acquisitions or dispositions; institution or commencement of material legal proceedings; ma- 
must file quarterly statements of profit and loss, and sources of funds and cash distributions to shareholders. ${ }^{59}$

The Commission has recently adopted a temporary exemption from the proxy rules under section 14 for securities registered under section $12(\mathrm{~g})$. The exemption runs until two months after the registration statement is due, or December 31, 1965, whichever is earlier. ${ }^{60}$ The exemption does not apply to solicitations of security holders by a company registered under the Holding Company Act. The exemption avoids acceleration of the date when the proxy rules apply if a company files a section 12 (g) registration statement prior to the required filing date.

Under amended section 14 all persons are prohibited from soliciting or permitting the use of their names to solicit proxies, consents or authorizations relating to securities registered pursuant to section 12 in contravention of such rules and regulations as the Commission may prescribe as necessary or appropriate in the public interest or for the protection of investors. Regulation 14, the Commission's proxy rules, is desigued to provide shareholders with an opportunity to exercise their corporate franchise on the basis of accurate and adequate information. The information required to be disclosed under these rules relates to both the matters to be voted on and the persons on whose behalf proxies are solicited. Thus, the contents of a proxy statement will vary with the matters to which the solicitation relates and the interest in such matters of the persons for whom the solicitation is being made. ${ }^{61}$

Under certain conditions, a shareholder may also require the management to place in the proxy statement his own proposals for action at the meeting, along with a brief supporting statement. ${ }^{22}$ Additional rules apply to proxy contests and require that both man-

terial changes in the terms of the issuer's securities; material defaults in senior securities; changes of more than $5 \%$ in the amount of any class of securities outstanding; material revaluations of assets; material restatements of capital share accounts; material grants or extensions of stock options; and the submission of any matter to a vote of security holders.

${ }^{80}$ Rule $13 \mathrm{a}-15$ provides for the filing of such reports on Form $7 \cdot \mathrm{K}$. The reports are due not more than sixty days after the end of the quarter for which they are filed, except that the report for the last quarter of a fiscal year is due within 120 days of the fiscal year end.

${ }^{\circ}$ SEC Securitics Exch. Act Rule 12g-1 (b), SEC Securities Exch. Act Release No. 7429, Sept. 15, 1964.

${ }^{\circ 1}$ The items of disclosure are set forth in SEC Securities Exch. Act Reg. 14, Schedule 14A, 17 C.F.R. at 300 (1964).

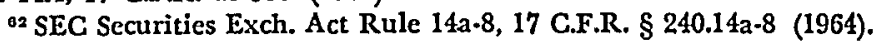


agement and other participants disclose information as to their interests in, and proposals with respect to, the issuer and make other disclosures in their proxy solicitation material. ${ }^{63}$ All proxy material must be filed with the Commission for examination by the staff prior to use, ${ }^{64}$ and the rules prohibit false and misleading statements in proxy solicitations. ${ }^{65}$

Under new section 14 (c), discussed in more detail below, the Commission is empowered to adopt rules and regulations requiring that issuers which do not solicit proxies in connection with any meeting of shareholders file with the Commission and transmit to record holders of registered securities information substantially equivalent to that which would be required to be transmitted if a solicitation were made. This section will not become operative until implemented by Commission rules.

Section 14 (a) does not apply to a solicitation of proxies to be voted at a meeting held after the effective date of a section 12 (g) registration statement, provided the solicitation is completed by the effective date. However, because it is frequently difficult to determine when a solicitation is completed, it may be advisable to conduct all proxy solicitations for such meetings under the proxy rules. Moreover, if no proxies are solicited by or on behalf of management under these rules, any Commission rules under section 14 (c) that are in force at that time should be checked to see if an information statement must be filed with the Commission and supplied to shareholders before the meeting.

Insiders of companies with securities registered pursuant to section 12 will be most directly affected by section 16 , which is de-

${ }^{\circ 3}$ SEC Securities Exch. Act Rule 14a-11, I7 C.F.R. \$ 240.14a-11 (1964); SEC Securities Exch. Act Reg. 14, Schedule 14B, 17 C.F.R. at 307 (1964).

od Rule 14a-6 provides for the filing with the Commission of three preliminary copies of the proxy statement, form of proxy and other soliciting material at least ten days prior to the date on which definitive copies are first sent or given to security holders, three preliminary copies of any additional solicitation material relating to the same meeting at least two days before copies are first sent or given to security holders, and four copies of the definitive material not later than the date on which they are first sent or given to any security holders.

${ }^{\circ S}$ SEC Securities Exch. Act Rule 14a-9, 17 C.F.R. $\$ 240-14 a-9$ (1964). Recently, in the first case decided by the Supreme Court involving implied liability under the federal securities laws, it was held that the federal courts have jurisdiction to entertain a private cause of action for violations of this rule in connection with a solicitation of stockholder approval for a merger. J. I. Case Co. v. Borak, 377 U.S. 426 (1964). For a thorough discussion of the problems relating to private causes of action for violations of the proxy rules, see 2 Loss 932-1019. 
signed to discourage corporate officials from using "inside" information for the purpose of speculating in the stock of their corporations. Section 16 (a) requires each officer and director of an issuer of registered equity securities and each holder of more than 10 percent of any class of such securities to file with the Commission and the appropriate exchange (if the security is listed) an initial statement of his orvnership of all equity securities of the issuer and monthly reports when changes in ownership take place. The statute provides for the filing of the initial reports by the effective date of a section $12(\mathrm{~g})$ registration statement, and that subsequent reports be filed by the tenth day of the month following the one in which changes occur.

In a departure from the basic disclosure philosophy, section 16 (b) further provides for the recovery by or on behalf of a corporation of all profits realized by an insider from short-term trading, that is, any purchase and sale, or any sale and repurchase, of the corporation's equity securities within any six-month period. The provisions of section $16(\mathrm{~b})$ apply regardless of whether there has been actual use of inside information so as to permit recovery of all profits from any combination of purchases and sales within any six-month pexiod. ${ }^{80}$ Finally, section $16(\mathrm{c})$ attacks some common manipulative techniques-short-selling and selling against the "box"-by prohibiting insiders of companies with securities registered under section 12 from selling shares of their corporation's equity securities which they do not own, or if owned, from delivering, or depositing for delivery, such shares later than the times specified in the statute.

The Amendments Act raises the question whether sections 13, 14 and 16 apply to securities which are required to be, but which have not been, registered under section $12(\mathrm{~g})$. A literal reading of the amendments suggests a negative answer, since sections 13, 14 and 16 speak only in terms of "securities registered pursuant to section

\footnotetext{
${ }^{60}$ Insiders of companies with securities listed on an exchange have been held liable under $\$ 16(b)$ for profits realized from sales of the issuer's equity sccurities even though at the time of the matching purchase the issuer's securitics had not been listed for exchange trading. Heli-Coil Corp. v. Webster, 222 F. Supp. 831 (D.N.J. 1963); Perfect Photo, Inc. v. Grabb, 205 F. Supp. 569 (E.D. Pa. 1962). Cf. Adler v. Klawans, 267 F.2d 840 (2d Cir. 1959). There has been considerable judicial gloss over $\S 16$ (b), and it can be a trap for the unwary. For comprehensive discussions of the developing law, sce 2 Loss 1037-132; Cook \& Feldman, Insider Trading Under the Securities Exchange Act, 66 Harv. L. Rev. 385-422, 612-41 (1953). For a critical view, sce Painter, The Evolving Role of Section 16(b), 62 Mich. L. REv. 649 (1964).
} 
12."'67 However, under the Investment Company Act, which contains numerous provisions expressly stated to be applicable only to "registered" investment companies, the Commission has held,88 and the courts have implicitly assumed, ${ }^{69}$ that it would be "plainly unreasonable" to permit an investment company to insulate itself from the provisions of the act by failing to comply with the registration requirements. A failure to register does not prohibit trading in the securities. ${ }^{70}$

\section{The Coverage Criteria}

Section 12 (g) (1) contains three separate coverage criteria. An issuer must register a class of security only if it meets all three tests and is not otherwise exempt. The three tests are applied only as of the last day of the issuer's fiscal year, and different results at other times during the year are immaterial. ${ }^{71}$

First, the issuer must be engaged in interstate commerce or a business affecting interstate commerce, or have securities traded by use of the mails or instruments of interstate commerce. This test is jurisdictional and appears to reflect the widest possible exercise of the federal commerce power. Since virtually every issuer meeting the other two criteria will have the necessary nexus with interstate commerce, it has little exclusionary significance.

Second, the issuer must have total assets in excess of one million dollars. The asset test was proposed by the Commission to relieve

${ }^{07}$ Section 3 (c) of the Commission's April 19, 1963, draft of the bill, submitted for comments to the Industry Liaison Committee, provided that "the provisions of section 13, section 14, section 16 and subsection (c) of section 20 of this title shall apply as if any security of a class registered or required to be registered pursuant to [section 12 (g)] ... were a security registered pursuant to [section 12(b)] . . ." House Hearings, pt. 1, at 658. (Emphasis supplied.) Comparable provisions with respect to $\$ \S 14$ and 16 also appeared in S. 1168, 85th Cong., 1st Sess. (1957); S. 2054, 84th Cong., 1st Sess. (1955); S. 1860, 82d Cong., 1st Sess. (1951); S. 2408, 8Ist Cong., 1st Sess. (1949). (All reprinted, Senate Hearings 461-68.)

${ }^{\circ 8}$ Townsend Corp. of America \& Townsend Management Co., SEC Investment Co. Act Release No. 4045, pp. $41-42$ (Sept. 2, 1964).

${ }^{\circ 0}$ Cogan v. Johnston, 162 F. Supp. 907, 909 (S.D.N.Y. 1958); Schwartz v. Bowman, 156 F. Supp. 361, 364 (S.D.N.Y. 1957), appeal dismissed sub nom. Schwartz v. Eaton, 264 F.2d 195, 198 (2d Cir. 1959). In view of these authorities, inferences from the lack of an express statutory reference to securities "required to be registered" can run either way; it either indicates a "clear" intent to exclude them from the operation of $\$ \S 13,14$ and 16 , or it reflects the view that such securities would be covered in any event. The legislative history is silent as to the validity of either explanation. See note 55a supra.

${ }^{70}$ See H.R. REP. No. 1418, 88th Cong., 2d Sess. 11 (1964) [hereinafter cited as House REPORT]; 110 CONG. REC. 17596-97 (daily ed. Aug. 5, 1964); discussions of foreign securities and $\S 15$ (c) (4) infra.

71 SENATE REPORT 60; House Hearings, pt. 1, at 214. 
small companies from obligations under sections $12,13,14$ and 16, because the costs of compliance by such companies and of administration by the Commission might be out of proportion to the size of the investor interest to be protected. ${ }^{2}$ The Commission has estimated that it will eliminate from the registration requirements 17 percent of the companies that would otherwise be covered..$^{73}$

Third, the issuer must have a class of equity security held of record by at least 750 persons and, after July l, 1966, by at least 500 persons. The shareholder test is the most significant of the three criteria, both in terms of its exclusionary impact and as a relevant measure of the public need for disclosure of information material to investment decisions; it best serves the function of excluding thousands of close corporations, while reaching those securities in which there is the greatest amount of trading interest. ${ }^{74}$ For botli foreign and domestic issuers, all American and foreign holders of record are included in computing the number of persons holding securities. ${ }^{75}$

a. The Asset Test

Both the House and Senate Reports clearly state that the term "total assets" means gross total assets, ${ }^{70}$ so that liabilities cannot be deducted from assets. Thus, registration may be required for securities of companies with thin equities, and even for those of companies which may be insolvent. In other respects neither the Amendments Act nor its legislative history provides significant indications as to the meaning of "total assets." Section $12(\mathrm{~g})(5)$ does, however, grant the Commission authority to define that term for purposes of section $12(\mathrm{~g})(1)$. The Commission has proposed Rule

${ }^{72}$ Senate Report 52; Senate Hearings 283; House Hearings, pt. 1, at 170. The Special Study found that there was no pattern of relationships between size of assets and number of shareholders among the sample of companies which it surveyed. Although it.concluded that the asset test was neither necessary nor appropriate, it recognized that the test may have relevance in limiting a disproportionate regulatory burden. Special Study, pt. 3 , at $18,26,34$.

${ }^{73}$ SENATE REPORT 52; Senate Hearings 395; House Hearings, pt. 1, at 169.

7*'The Special Study estimated that the securities of over 11,000 issuers (excluding listed and foreign securities) were quoted by at least one broker-dealer in the quotation sheets of the National Quotation Bureau at one or more times during a ten month period in 1961, but that only 5,300 of these issuers had a class of security held of record by 500 or more persons. On the basis of a survey of a sampling of these issuers, it concluded that the shareholder test is a better measure of trading activity than all other criteria examined. The Study recommended a single coverage criterion of 300 holders. Special Study, pt. 3, at 17-35.

${ }^{75}$ SENATE REPORT 30; House Hearings, pt. 1, at 180.

7* SeNate Report 60; House Report 15. 
12g5-2, which would define "total assets" as those shown on the balance sheet of either the issuer or the issuer and its subsidiaries consolidated, whichever is the larger, "as required to be filed on the form prescribed for registration under this section and prepared in accordance with the pertinent provisions of Regulation S-X."77

Regulation S-X, the Commission's general accounting regulation, prescribes the form and content of financial statements required to be filed with the Commission pursuant to the various acts and rules and regulations thereunder. Article 3-II of Regulation S-X requires that valuation and qualifying reserves, such as those for depreciation and bad debts, be shown separately in financial statements as deductions from the specific assets to which they apply. Regulation S-X does not, however, prescribe the methods to be followed for computing reserves or for valuing assets. The absence of detailed rules is consistent with the Commission's general policy, in the administration of the disclosure requirements, of accepting financial statements prepared in accordance with differing accounting principles provided the method chosen is supported by substantial authority, is adequately disclosed and does not unfairly portray the financial condition or the earnings of the company. ${ }^{78}$ Although the Commission's adherence to this policy in the context of the asset test may result in some lack of uniformity in the application of section 12 (g) (1), this factor alone may not prove important enough for the Commission to undertake the formidable task of choosing among alternative methods of valuation where there is a substantial difference of opinion within the accounting profession.

For the purpose of determining total assets under section $12(\mathrm{~g})(1)$, proposed Rule 12g5-2, in general, follows Regulation S-X with respect to the use of consolidated balance sheets. Article 4 of Regulation S-X requires that registrants follow, in the consolidated statements, principles of inclusion or exclusion which will clearly exhibit the financial condition and results of operations of the registrant and its subsidiaries, but forbids consolidation of subsidiaries which are not majority-owned. Consolidation is also forbidden by companies in the promotional, exploratory or developmental stages,

\footnotetext{
${ }^{77}$ SEC Securities Exch. Act Release No. 7426, Sept. 15, 1964.

78 Rappaport, SEC Accounting Practice and Procedure 3.1-3.2 (2d ed. 1963); House Hearings, pt. 2, at 1297-347, 1756-61. For an excellent discussion, see Barr, The Influence of Government Agencies on Accounting Principles With Particular Reference to the Securities and Exchange Commission, Mick. C.P.A., March-April 1964, p. 5.
} 
and in a number of other particular situations. Thus, when consolidation is not required under Regulation S-X, total assets need not be computed on a consolidated basis for the purpose of section 12 (g) (1). However, under proposed Rule 12g5-2, consolidated figures would be disregarded if the issuer's balance sheet shows larger total assets, even though consolidation would be required under Regulation S-X. When consolidated figures are not used, Regulation $\mathrm{S}-\mathrm{X}$ does not specify whether book value of the issuer's equity in its subsidiaries or original cost must be shown on its balance sheet, and in some situations the Commission has accepted either method of valuation. Proposed Rule 12g5-2 would not affect this position.

Although proposed Rule $12 \mathrm{~g} 5-2$ refers to a balance sheet prepared in accordance with Regulation S-X, the absence of a properly prepared balance sheet does not affect the Commission's burden of proof to show that an issuer failing to register has met the asset test. However, it may be expected that the Commission will question closely asset figures not in excess of one million dollars shown on balance sheets which are not certified by independent accountants or prepared in accordance with established accounting practices.

\section{b. The Shareholder Test}

The precise scope of the shareholder test contained in section 12 (g) depends on the definitions given to its key terms-"equity security," "class" and "held of record." Although all three terms appear elsewhere in the Exchange Act ${ }^{70}$ or rules thereunder, their definition raises a number of new and interesting questions in the context of section $12(\mathrm{~g})$.

(1) Equity Security. Section 3 (a) (11) of the Exchange Act provides a broad definition of the term "equity security." It includes: (1) any stock or similar security; (2) any security convertible into such a security, or carrying any warrant or right to subscribe to such a security; (3) any such warrant or right; and (4) any other security which the Commission deems of similar nature and by rule

${ }^{79}$ The insider trading provisions apply only to "equity securities." The concept of "class" is significant in several contexts: section 16 applies to owners of morc than $10 \%$ of a "class" of equity security; the undertaking to filc reports pursuant to $\$ 15$ (d) bccomes operative when the value of the securities registered under a Sccuritics Act registration statement plus the valuc of the outstanding shares of the same "class" cxceeds $\$ 2,000,000$; and under Rule 12dl-1 an application for registration is decmed to cover the entire "class" of securities. "Held of record" is used in Rulc 15d-20, which prescribes exemptive standards for closely held companies required to file reports under $\S 15$ (d). 
or regulation considers necessary in the public interest or the interest of investors to treat as an equity security. Under section 3 (a) (11) pure debt obligations carrying no voting rights and having a fixed maturity date and rate of return are not equity securities. On the other hand, these same obligations become equity securities if they are convertible into stock or carry warrants or rights to subscribe to stock. ${ }^{80}$ Clearly, the phrase "any stock" includes preferred stock, and the Commission has also taken the position that voting trust certificates and certificates of deposit are equity securities when the underlying securities are..$^{81}$

Neither section 3 (a) (11) nor the legislative history of either the original Exchange Act or the Amendments Act provides guidance on whether hybrid debt obligations such as income bonds or voting debentures carrying some of the attributes of equity interests are equity securities for purposes of section 12 (g). It has been argued that the term "similar security" in section 3 (a) (11) was intended to encompass these securities. ${ }^{82}$ Professor Loss suggests, however, that the term might be intended to refer only to stock-like interests of noncorporate issuers. ${ }^{83}$ The broad rulemaking power of section 3 (a) (11) gives the Commission adequate means to resolve this uncertainty for some of the more commonly used hybrid instruments, but it is probably impractical to attempt, by rule, to reach every variety of these instruments for which registration under section $12(\mathrm{~g})$ would be appropriate.

(2) Class. By providing for the registration of classes of securities, rather than securities, section $12(\mathrm{~g})(1)$ incorporates a concept employed by the Commission to eliminate unnecessary filings for the registration of new securities belonging to a class previously registered for exchange trading under section 12 (b).${ }^{84}$ Under section

\footnotetext{
${ }^{80}$ But if the warrants or rights are detachable and transferable separately, it may be argued that only the warrants or rights, and not the bonds, are equity securities subject to registration under $\$ 12(\mathrm{~g})$.

81 House Hearings, pt. 2, at 1353-54 (semble); 2 Loss 1095. See also SEC Securities Exch. Act Rule 16a-2, 17 C.F.R. $\$ 240.16 a-2$ (1964), providing that for the purpose of determining $10 \%$ ownership of a class of equity security, "the class of voting trust certificates or certificates of deposit shall be deemed to consist of the entire amount of voting trust certificates or certificates of deposit issuable in respect of the class of equity securities which may be deposited under the voting trust agreement or deposit agreement in question, whether or not all of such class has been so deposited."

${ }^{83}$ Cook \& Feldman, supra note 66 , at $394-95$.

832 Loss 1095 n.232.

8s Section 12 (b) provides for the registration of securities rather than classes of securities. For many years, issuers could register only as many units of a class of listed
} 
$12(\mathrm{~g})$, however, the concept of class assumes jurisdictional significance.

Section $12(\mathrm{~g})(5)$ defines "class" for purposes of section 12 (g) as including "all securities of an issuer which are of substantially similar character and the holders of which enjoy substantially similar rights and privileges." Although this definition, which was taken verbatim from section 15 (d), is vague, the Commission could adopt supplemental definitions pursuant to its authority to define technical, trade and accounting terms under section 3 (b) of the Exchange Act. ${ }^{85}$

The statutory definition does indicate that minor differences in the character of different securities will be disregarded in a determination of class for purposes of section $12(\mathrm{~g})$. Moreover, in Ellerin v. Massachusetts Mut. Life Ins. Co., ${ }^{86}$ the only litigated case under the federal securities laws involving the definition of class, the court followed a broad approach in holding that the defendant was not a holder of more than 10 percent of an issuer's preferred stock. In this case arising under section $16(\mathrm{~b})$, the preferred stock was issued in two series with the defendant owning more than 10 percent of one series but less than 10 percent of both series combined. The two series differed in their issuance dates, dividend rates, redemption prices and sinking fund arrangements, but each series had the same par value, voting rights and preferences with respect to dividends and liquidation. The court found that the differences between the two series were dictated by conditions in the financial market at the time of issuance, and that, as recognized by the corporation codes of many states, both series were part of a single class of preferred stock.

sccurities as had been issued, and a new registration statement was required for additional securities of the same class that were subsequently issued. In 1954 the Commis. sion greatly simplified the registration provisions by adopting Rule 12d1-1, which provides that all applications for registration are deemed to cover the registration of the entire class upon the effective date and automatically extend to additional securitics of the same class upon issuance. However, when securities are issued in two or morc series with different terms, each series is considered a separate class. SEC Securities Exch. Act Rule 12d1-1 (d), 17 C.F.R. § 240.12d1-1 (d) (1964). Under the class registra. tion concept the Commission does not normally require a new registration application for securities created in connection with stock splits or for changes in par value in tlie securities of a registered class. See 2 Loss 789-92.

8s SeNATE REPORT 62. The Senate Report makes it clear that this specific definition in $\$ 12(\mathrm{~g})(5)$ does not limit the Commission's authority to further define the term "class" under its power in $\$ 3(\mathrm{~b})$ to define technical, trade and accounting terms. Ibid. See also House Hearings, pt. 1, at 215-16.

se 270 F.2d 259 (2d Cir. 1959). 
The Ellerin case was decided under section 16 (b), which does not have the "substantially similar" definition of sections $12(\mathrm{~g})$ and 15 (d). It seems likely that an even broader approach would be justified for purposes of the shareholder test of section 12 (g). In reaching a determination of class, considerable emphasis might be placed on any surrounding circumstances which show that formal distinctions among different securities of an issuer have little practical significance from the standpoint of an investment decision. Thus, whether differences in dividend preferences would be deemed suffcient to result in different classes of securities might depend on the earnings of the issuer, differences in liquidation preferences on the insolvency of the enterprise, and differences in voting and preemptive rights on the control position of insiders.

An even more difficult question arises with respect to whether convertible debentures and the securities into which they are convertible belong to the same class. When conversion rights cannot be exercised until the distant future or upon the occurrence of specified contingencies presently remote, there may be significant distinctions between the interests of the holders of the two securities. But when the debentures are convertible immediately or within a relatively short period of time or upon the occurrence of an imminent event, the debenture holders have much the same need for information concerning the issuer as have holders of the security into which the debentures are convertible. To separate these securities into two classes, under these circumstances, would provide an inadequate measure of investor interest and deprive significant classes of investors of the information material to investment decision at the point when the information would be most useful.

The concept of "class" seems to have little functional relationship to the shareholder test as a measure of public investor interest in over-the-counter issuers. Nor is it a relevant concept in the context of the Commission's disclosure requirements, which relate to information concerning the issuer and its management to a far greater extent than to the terms of particular classes of securities. The use of the class concept in section 12 (g) does eliminate the need for Commission rules to prevent unnecessary filing, and may be appropriate for purposes of section 16 when one or more classes of an issuer's securities are closely-held. It could, however, produce an unwarranted lack of uniformity and provide a ready means of avoiding dis- 
closure obligations under the Exchange Act. ${ }^{87}$ For these reasons, the Commission would be justified in adopting the broadest possible definition of class for purposes of section 12 (g).

(3) Holders of Record. The application of the term "held of record" to securities held in street name and by nominees, trusts, partnerships and corporations, as well as to bearer certificates, voting trust certificates and depositary receipts, raises a host of questions. In large measure, the Amendments Act delegates resolution of these questions to the Commission. Although the shareholder test of section $12(\mathrm{~g})$ is based on the number of record holders, section 12 (g) (5) authorizes the Commission, by rule or regulation, to define "held of record" for purposes of section 12 (g) "as it deems necessary or appropriate in the public interest or for the protection of investors in order to prevent circumvention [of section $12(\mathrm{~g})]$...."

The exercise of this definitional authority apparently is not limited to arrangements deliberately entered into for the purpose of circumvention, since the Commission specifically indicated to Congress that it would be used to deal with such devices as voting trusts ${ }^{88}-$ arrangements which are commonly employed for a variety of bona fide purposes. Thus, section 12 (g) (5) seems intended to authorize the Commission to extend the definition of "held of record" beyond its ordinary meaning in order to reach security holders not identified on the records of issuers, regardless of the reason for the form of holding, whenever such a definition is necessary to obtain an accurate measure of public investor interest in a class of securities. However, the term "held of record" was used in section 12 (g) because "issuers generally cannot readily ascertain the number of beneficial owners of securities." 89 This suggests that consideration must also be given to the difficulties created when issuers would be required to look beyond their record books to determine whether they meet the shareholder test.

Proposed Rule 12g5-1, the definition of "held of record" pub-

87 The Special Study found that only $22.4 \%$ of the companies surveyed had more than one class of stock outstanding, and it concluded that measurement of the number of shareholders by classes of securities would not significantly affect coverage. Special Study, pt. 3, at $20 \mathrm{n} .43$. However, this result could change if avoidance of registration becomes an important factor in determinations as to the form of public financing.

${ }^{88}$ Senate Hearings 395.

${ }^{89}$ Ibid. The Special Study recommended that the shareholder test include known beneficial holders. Special Study, pt. 3, at 62 . 
lished for comment by the Commission, reflects these factors..$^{90}$ For purposes of sections $12(\mathrm{~g})$ and $15(\mathrm{~d})$, it provides that a holder of record shall include each person identified as an owner or co-owner on the issuer's records of security holders. The proposed rule does not specify the form or contents of these records, but paragraph (a) (l) includes as a holder of record any person who would be identified as such if the records were properly maintained. Neither the proposed rule nor the accompanying Commission release provides any indication as to the meaning of "properly maintained." Presumably it requires, at the least, that the records be maintained according to customary practice, and that they conform to the applicable requirements, if any, of state law and of the issuer's charter and by-laws, and, if maintained by a transfer agent, to the terms of any agreement between the issuer and the transfer agent. Presumably, the records also must be complete, reflecting all properly submitted requests for stock certificates received by the date as of which the number of record holders is being measured.

Paragraphs (a) (2) and (a) (3) contain the proposed rules with respect to securities held by corporations, partnerships, trusts and persons in other fiduciary capacities. Securities held of record by a corporation or partnership, whether or not the partners are identified, would be included as held by one person. Each trust (whether the securities are held in the name of the trust, one or more trustees, or both) would be deemed a single holder of record, and securities held by persons in other fiduciary capacities would be included as held of record by each separate account. Joint trustees, guardians or custodians would be included as single record holders.

These provisions would be qualified by paragraph (b) (4) which would provide that the beneficial owners are deemed the record owners if the issuer knows or has reason to know that the form of record holding is used primarily to circumvent the provisions of sections 12 (g) or $15(\mathrm{~d})$. This catch-all provision is directed against a variety of devices which could be employed to reduce the number of record holders below the statutory standards. Thus, it is intended to deter the organization of holding companies, subsidiaries or trusts for the primary purpose of avoidance.

Proposed Rule 12g5-1 also contains a number of other provisions. First, paragraph (a) (4) specifies that securities held by two persons

\footnotetext{
${ }^{D 0}$ SEC Securities Exch. Act Release No. 7426, Sept. 15, 1964.
} 
with the same surname shall be included as held by a single person. This provision recognizes that joint ownership by husband and wife usually reflects a single investment decision and, consistent with the measure of investor interest intended by the shareholder test, should be regarded as held by one person. Since issuers' records may not iclentify co-owners as husband and wife, the rule would extend to all securities held by two co-owners with the same surname.

Second, paragraph (a) (5) provides that each outstanding bearer or unregistered certificate be included as held by one person unless the issuer can establish that such certificates would be held of record, under the provisions of the rule, by a lesser number of persons if they were registered. Although the issuance of unregistered certificates is relatively rare in the United States, it is the usual practice in continental European countries, and, in recent years, a number of issues of convertible debentures of United States companies have appeared in unregistered form. The proposed rule might place a difficult burden of proof on issuers of unregistered certificates, but there seems to be no other feasible way to cleal with bearer certificates unless they are to be ignored for purposes of sections 12 (g) and $15(\mathrm{~d})$.

Third, paragraph (b) (l) provides that the record holder of voting trust certificates, certificates of deposit or similar evidences of a security interest, rather than the voting trustees or depositaries, be deemed the holder of record of the underlying security. Although this provision departs widely from the literal meaning of "held of record," the cleparture is justified by the substantial identity of interest between holders of voting trust certificates or certificates of deposit and holders of the underlying security. However, registration under section $12(\mathrm{~g})$ would be required only for the underlying security unless the class of certificates separately satisfied the coverage criteria of section $12(\mathrm{~g}) \cdot{ }^{91}$ The disclosures applicable to the un-

${ }^{21}$ This raises the interesting question whether the Commission can define "held of record" so that for purposes of computing holders of record of the underlying security, that security is deemed to be held of record by the certificate holders, but for purposes of determining whether the voting trust or similar entity must register under $\S 12(\mathrm{~g})$, the certificates are considered a separate security. It is fairly clear that voting trust certificates and American depositary receipts (ADR's) are securities separate from the underlying securities, see SEC Securities Act Form F-1, 17 C.F.R. § 239.9 (1964); SEC Securities Act Form S-12, 17 C.F.R. $\$ 239.19$ (1964), and that they are equity securities at least when the underlying securities are. See note 81 supra and accompanying text. Moreover, $\S 12(\mathrm{~g})(3)$ of the Amendments Act and the Commission's exemptive rule for foreign securities and ADR's, SEC Securitics 
derlying securities could be material to the certificate holders even when sections 12, 13, 14, and 16 are not applicable to the certificates. The proposed rule might pose some problems if an issuer encountered difficulty in obtaining the number of certificate holders from the trustees or depositaries. However, the Commission has authority under section 21 to subpoena this information in connection with an investigation into violations of the Exchange Act, and issuers will be able to protect themselves adequately by reporting the matter to the Commission.

Fourth, paragraph (b) (2) requires that securities of an issuer held by its employees' stock purchase, savings, pension, retirement or similar plans, or a plan of its affiliates, ${ }^{92}$ be deemed held of record by the persons who have a direct beneficial interest in the securities. This provision also represents a departure from the literal meaning of "held of record," but it requires only that issuers look to records which generally are as readily available to them as the records of their own security holders. Since paragraph (b) (2) refers to "persons who have a direct beneficial interest," it would not include as holders of record the beneficiaries of the employee's interest. Moreover, since the rule applies only to securities held by a plan, it also would not normally reach securities held by a commingled investment fund managed by a bank, insurance company or investment adviser in which funds of the plan have been placed unless the primary purpose for using the commingled fund is to circumvent section 12 (g) or $15(d)$.

Paragraph (b) (2) seems unclear in two respects. Does "a direct beneficial interest" include an interest which is not vested under

Exch. Act Rule 12g3-1, SEC Securities Exch. Act Release No. 7427, Sept. 15, 1964, indicate that registration under $\S 12(\mathrm{~g})$ might be required of ADR's. Registration of voting trust certificates and ADR's would not necessarily be inconsistent with a rule that the underlying securities are deemed to be held of record by the record holders of the voting trust certificates or ADR's in light of the Commission's broad powers to define "held of record." The discussion of inactively traded and foreign securities infra is relevant in this regard. The effect of the "total assets" test in this context is unclear.

"The term "affiliate" is not defined in the Exchange Act, and the new definition of "affiliated person" in $\$ 3$ (a) (19) is apparently not applicable. However, SEC Securities Exch. Act Rule 12b-2, 17 C.F.R. $\$ 240.12 b-2$ (1964), defines an affihate as "a person that directly, or indirectly through one or more intermediaries, controls, or is controlled by, or is under common control with, the person specified." This definition would seem appropriate for the purposes of Rule 12g5-1 (b) (2). The Commission, under the various acts, has adopted a broad approach to the question of control. See 2 Loss 764-83; Comment, The Meaning of "Control" in the Protection of Investors, 60 YALE L.J. 311 (1951). 
the plan? And since it refers to an interest in the securities held by the plan rather than an interest in the plan, is this provision limited to plans under which the employees have the right to receive benefits in securities rather than cash? Moreover, paragraph (b) (2) might produce some incongruous results when applied to plans in which the employer's securities constitute only a small portion of the entire portfolio, since even in these situations all the participants in the plan would be included as record holders of the employer's securities.

Fifth, paragraph (b) (3) deals with securities held in street name, a form of holding which embraces a significant portion of securities outstanding and tends to be most common in actively traded stocks where the need for disclosure is accentuated.93 Although other alternatives could have been chosen, the rule proposed by the Commission is consistent with a recognition of the difficulties that issuers might encounter in ascertaining beneficial ownership. The proposed rule would require that securities held of record by brokers, dealers, banks or their nominees be included as held of record by the number of separate customers or custodial and investment advisory accounts for which they are being held. This requirement, however, is hedged by a number of exculpatory conditions designed to protect issuers who cannot readily obtain the necessary information. The issuer or person maintaining its security holder records need only request information from those registered owners which it knows are brokers, dealers, banks or nominees of such firms, and the rule expressly states that the issuer may rely in good faith on such information as is received in response to the request. Moreover, the rule provides that the recipient of a request need furnish information only to the extent it can be readily supplied.94

\footnotetext{
${ }^{93}$ A study by the New York Stock Exchange in 1962 indicated that $7.67 \%$ of the shares of all publicly held corporations in the United States were registered in the names of brokers or dealers, $13.7 \%$ in the names of nominees and $6.6 \%$ in the names of fiduciaries. New York Stock Exchange, 1962 Census of Shareowners in AMerica 36 (1962). The Special Study found that $40 \%$ of all over-the-counter issuers surveyed by it had from 10 to $29 \%$ of their shares registered in the names of broker-dealers or bank nominees. Special Study, pt. 3, at 20, 103.

${ }^{0 s} 1 \mathrm{t}$ is not clear whether the proposed rule requires broker-dealers, banks and their nominees to respond to such requests, though they clearly need not do so if the information cannot be "readily supplied." The Commission probably could affirmatively impose such reporting requirements on broker-dealers registered under $\$ 15(b)$ and exchange members pursuant to its rulemaking authority under $\S 17$ (a), since that section is not limited to reports to be filed with the Commission. There is no comparable authority under the Exchange Act with respect to banks.
} 
Proposed Rule 12g5-1 is, of course, subject to revision in light of the comments received by the Commission and the Commission's experience in the administration of sections 12 and 15 (d). As presently proposed, it generally presents a sensible solution to the difficult problem of obtaining an accurate measure of investor interest while avoiding an undue burden on issuers. By neither accounting for every beneficial interest in a class of securities nor entirely relieving issuers of the responsibility for looking beyond their own record books to ascertain the need for registration under section 12 (g) or reporting under section 15 (d), it could provide a workable and fair basis for the application of the shareholder test to over-thecounter companies. ${ }^{95}$

\section{Banks}

The Amendments Act applies to securities of banks to the same extent as to those of other over-the-counter issuers. However, with respect to both over-the-counter and listed securities issued by banks with deposits insured pursuant to the Federal Deposit Insurance Act, ${ }^{96}$ section 12 (i) provides for the administration and enforcement of sections $12,13,14(\mathrm{a}), 14(\mathrm{c})$ and 16 by the three federal banking agencies. The banking agencies designated in section 12 (i) are the Comptroller of the Currency for national and District of Columbia Banks, the Board of Governors of the Federal Reserve System for all other member banks of the Federal Reserve System, and the Federal Deposit Insurance Corporation for all other insured banks. The Commission will administer and enforce these provisions for any financial institution which is not a "bank," and for the few noninsured banks which meet the coverage criteria of section $12(\mathrm{~g}) \cdot{ }^{97}$ Bank holding companies and bank affiliates also will be required to register with the Commission rather than with a federal banking agency. ${ }^{98}$

${ }^{05}$ The Commission's proposed rule does not go nearly so far in its definitional effect as Rule 15d-20.

${ }^{00} 64$ Stat. 873 (1950), 12 U.S.C. $\$ \S 1811-31$ (1958), as amended, 12 U.S.C. $\$ \S 1812-$ 28 (g) (Supp. V, 1964).

${ }^{\circ}$ SENATE REPORT 63. The Commission has estimated that the deposits of only four of the banks subject to $\S 12(\mathrm{~g})$ are not insured in accordance with the Federal Deposit Insurance Act. Senate Hearings 17; House Hearings, pt. 2, at 1364.

"A bank holding company is not deemed a "bank" within the meaning of $\S 3$ (a) (2) of the Securities Act, which exempts from registration "any security issued or guaranteed ... by any national bank, or by any banking institution organized under the laws of any State or Territory or the District of Columbia, the business of which is substantially confined to banking and is supervised by the State or Territorial banking commission or similar official." See 1 Loss 566. 
The Amendments Act reverses the position of banks under the Exchange Act and under previous bills to extend disclosure requirements to over-the-counter securities. ${ }^{09}$ Although banks are extensively regulated by state and federal authorities, the Special Study demonstrated that traditional banking regulation was oriented toward the protection of depositors and has failed to satisfy the need of bank investors for adequate information material to investment decisions. ${ }^{100}$ Section 12 (i) is designed to meet this need in a manner acceptable to both the banking industry and the Commission. ${ }^{101} \mathrm{Al}$ though administration by the three federal banking agencies could produce a considerable lack of uniformity in disclosure practices within the industry, it does provide for the integration of, and reconciliation of any conflict between, investor and depositor protections.

The Senate Report ${ }^{102}$ and a later Commission memorandum to

${ }^{99}$ Prior to the Amendments Act, $\$ 12$ contained no exemption from registration for bank securities traded on national securities exchanges. Early in the administration of the Exchange Act, however, the Commission issued a "temporary cxemption" from registration for all listed bank securities until adoption of an appropriate registration form. SEC Securities Exch. Act Rule 12a-1, 17 C.F.R. $\$ 240.12 a-1$ (1964). Since virtually all bank securitics have been traded in the over-the-counter market and on three exchanges exempted from registration as national securitics exchanges, the Commission has never adopted an appropriate form. Special Study, pt. 3, at 36. All of the earlier bills introduced in the Senate to extend disclosure obligations to over-tlecounter issuers provided exemptions for bank securitics. Sec notes 45, 47, 48 supra; Senate Hearings 461-68.

100 The Special Study found scrious deficiencics in the financial reporting and proxy solicitation practices of the banks which it examined, and concluded that the protections of $\S \S 13,14$ and 16 are needed for bank shareholders. Special Study, pt. 3, at 35.39.

101 With respect to bank securities, $\S 3$ (e) of S. 1642, H.R. 6789 and H.R. 6793, as originally introduced, provided for delegation of the Commission's powers, duties and functions under the Exchange Act to the appropriate federal banking authority upon request of such agency. S. 1642 was amended in the Scnate with the concurrence of the Commission after the American Bankers Association announced that it would support the bill if it were amended to provide for mandatory rather than discretionary administration by the federal banking agencies. SENATE REPORT 34; Senate Hearings 247-53; House Hearings, pt. 2, at 1367-70, 1375-77. The Federal Deposit Insurance Corporation (FDIC) voiced no objection to the bill as amended. SEnATE REPORT 35; Senate Hearings 225-28. The Federal Reserve Board (FRB) strongly supported the application of the Exchange Act to bank securities, but preferred that administration be left to the Commission. Senate Report 34-35; Senate Hearings 167-70, 223-25; House Hearings, pt. 1, at 65-66. The Comptroller of the Currency, who alone among the banking agencies had recently adopted investor-oriented disclosure requirements applicable to national and District of Columbia banks, vigorously sought an exemption for sucl banks. He contended that his existing authority, as well as that of the FDIC and FRB, was adequate to accomplish the purposes of the Icgislation, and that if additionat legislation were deemed necessary it should consist of amendments to the bank regulatory statutes. SenATE RePORT 35; Senate Hearings 171-83; House Hearings, pt. 2, at 1356-60.

${ }^{102}$ Senate Report 36, 63-64. 
the House Subcommittee ${ }^{103}$ emphasize that section 12 (i) effects a broad delegation of the Commission's administrative and enforcement authority under the Exchange Act to the federal banking agencies. This broad delegation encompasses powers derived from sections of the act other than sections 12, 13, 14 (a), 14(c) and 16 . Thus, it includes the power to define "equity security" under section 3 (a) (11) and technical, trade and accounting terms under section 3 (b); it includes the power to adopt rules and regulations necessary for the performance of functions under the act pursuant to section 23 (a), and to extend confidential treatment under section 24 to information filed pursuant to the provisions of the act. Undoubtedly, that portion of section 23 (a) which grants immunity for any acts done or omitted in good faith reliance upon rules ${ }^{104}$ promulgated by the Commission and the Board of Governors of the Federal Reserve System also applies to the rules of the Comptroller and the Federal Deposit Insurance Corporation. The federal banking agencies, pursuant to new section 15 (c) (4), also have authority to issue an order to compel compliance with sections 12 and 13. For violations of the sections they administer, they can also delist a bank security from a national securities exchange under section 19 (a) (2), suspend trading in a bank security for periods of ten days pursuant to new section 15 (c) (5) and section 19 (a) (4), and investigate, issue subpoenas, institute suits to enjoin, and transmit evidence of violations to the Attorney General for criminal prosecution under section 21.

Other sections of the Exchange Act also apply to the functions of the federal banking agencies under the act. Thus, orders issued by such agencies under the Exchange Act would be appealable in the United States courts of appeals pursuant to section 25 (a). The United States district courts would have exclusive jurisdiction of violations of the act and rules thereunder with respect to bank securities, and of all suits in equity and actions at law brought to enforce any liabilities under the act with respect to such securities as provided in section 27 . The contract voiding provisions of section 29 (b) would apply to contracts involving bank securities made in violation of the act or any rule or regulation thereunder. ${ }^{105}$

\footnotetext{
${ }^{103}$ House Hearings, pt. 2, at 1360-67. See also House Fearings, pt. 1, at 217.

${ }^{104}$ Good faith reliance is a basis for inmunity even though the rule relied upon is subsequently held invalid.
} 
The legislative history of the Amendments Act emphasizes that the act does not derogate from the existing powers of the federal banking agencies to regulate disclosures by banks pursuant to any authority contained in other statutes. ${ }^{100}$ The Senate Report specifically states that the Comptroller, under his existing authority, could promulgate disclosure regulations with respect to national and District of Columbia banks which do not meet the coverage criteria of section $12(\mathrm{~g}) .^{107}$ Presumably, the powers of the federal banking agencies under the banking regulatory statutes, ${ }^{108}$ as well as

\footnotetext{
${ }^{105}$ Section 29 (b) provides that a contract made in violation, or the pertormance of which involves a violation, of any provision of the act or rules thereunder shall be void as against the rights of parties to the contract who, by making or performing the contract, commit the violation and any other persons who acquire such rights with actual knowledge of the violation. The implied liability doctrine is based in part on these provisions and in part on the statutory tort principle that, in the absence of evidence of legislative intent to the contrary, civil remedies will be afforded for injuries caused by violation of a statute to the class of persons whom the statute was intended to protect. See 3 Loss 1757-63. Sections 10.2 and 16.11 of the Comptroller of the Currency's new regulations implementing $\S \S 12,13,14$ and 16 of the Exchange Act expressly provide that no provision of the regulations "is intended to confer any private right of action on any stockholder or any other person against a national bank." 29 Fed. Reg. 12300,12305 (1964). While the Commission has played a major role in the development of the implied liability doctrine in the courts, it has also provided in Rule 17a-8 that noncompliance with the rule shall not affect the validity or effect of action taken by the exchange. Moreover, Rule $14 a-3$ requires that annual reports accom. panying or preceding proxy solicitation material shall be "mailed to the Commission, solely for its information," but provides that such reports shall not be deemed filed with the Commission and subject to the statutory civil liability provisions of $\S 18$. Rule 17a-8, however, is merely a procedural rule, which requires the filing with the Commission of proposed changes to rules of national securities exchanges prior to their adoption, and Rule 14a-3 does not extend to the implied liability doctrine. A provision of the proxy rules stating that noncompliance with the rules shall not invalidate any proxy pursuant to which action has been taken was deleted by the Commission on the ground that "the legal consequences of noncompliance with the proxy rules are for determination by the courts." SEC Securities Exch. Act Release No. 2376 , p. 4, Jan. 12, 1940. The implied liability doctrine as developed by the courts under the federal securities laws has become more significant in affording effective investor remedies than the statutory civil liability provisions contained in $\$ \S 11$ and 12 of the Securities Act and $\$ \S 9$ and 18 of the Exchange Act. The Comptroller's sweeping negation of these liabilities for violations of his regulations designed, in part, to imple. ment the Exchange Act brings into sharp focus the still unlitigated question of whether the express pronouncement and intent of an administrative agency acting in its legislative, rulemaking capacity can override a contrary policy imputed to Congress by the courts. The Comptroller would seem to be on stronger ground if his limitations on implied rights of action by bank investors were confined to those which find particular justification in the depositor-oriented policies of federal banking regulation.

${ }^{100}$ SENATE REPORT 35-36, 64; House Hearings, pt. 1, at 174, 217; id., pt. 2, at 1362. However, neither the FDIC nor the FRB has asserted jurisdiction under the banking regulatory statutes over bank disclosures to shareholders. House Hearings, pt. 2, at 1362 .

107 SENATE REPORT 35-36, 64.

${ }^{108}$ National Bank Act, 13 Stat. 99 (1864) (codified in scattered sections of 12 U.S.C.) (administered by the Comptroller of the Currency); Federal Reserve Act, 98 Stat. 251
} 
other provisions of these statutes which do not conflict with the provisions of the Exchange Act, would also be applicable to their functions under the Exchange Act.

In one significant respect, section 12 (i) detracts from the Commission's existing powers over bank securities. It transfers from the Commission to the federal banking agencies the authority to administer and enforce the provisions of the Exchange Act with respect to bank securities registered and listed for trading on a national securities exchange. This would include the power under section 12 (d) to regulate voluntary delistings of bank securities and under section $12(f)$ to regulate unlisted trading of bank securities. ${ }^{109}$ In all other respects section 12 (i) is not intended to affect the Commission's authority over bank securities existing prior to the Amendments Act. Thus, the Commission may enforce the anti-manipulation provisions of section 9 with respect to bank securities, and the antifraud rules under sections 10 and 15 (c) will continue to be applicable to such securities. The Commission could also suspend trading in bank securities under sections 15 (c) (5) and 19 (a) (4) for reasons other than violations of sections 12, 13, 14 (a), 14 (c) and 16. ${ }^{110}$ Furthermore, under section 12 (i) the federal banking agencies are not vested with the Commission's rulemaking authority under section $14(\mathrm{~b})$, relating to the transmission to beneficial owners of proxy material for securities registered under section 12 and held in street name by broker-dealers. ${ }^{111}$ Moreover, the Commission seemingly has not lost its authority to impose conditions on exemptions from registration as a national securities exchange, even though the conditions may affect bank securities traded on an exempt exchange. ${ }^{112}$

(1913) (codified in scattered sections of 12 U.S.C.) (administered by the Board of Governors of the Federal Reserve System); Federal Deposit Insurance Act, 64 Stat. 873 (1950), 12 U.S.C. $\$ \S 1811-31$ (1958), as amended, 12 U.S.C. \$§ 1812-28 (g) (Supp. V, 1964) (administered by the Board of Directors of the Federal Deposit Insurance Corporation).

${ }^{100}$ Although the legislative history is silent, this conclusion follows from the provisions of $\S 12$ (i) vesting in the federal banking agencies the powers, duties and functions of the Commission under $\S 12$.

110 SENATE REPORT 63; House Hearings, pt. 1, at 216; id., pt. 2, at 1365-67.

111 See discussion of $\S 14$ (b) infra.

112 There are now four securities exchanges which have been exempted from registration under $\$ 5$ : Honolulu, Colorado Springs, Richmond and Wheeling. The exemptions have been conditioned on compliance with virtually all the provisions of the Exchange Act except the reporting, proxy and insider trading provisions. 2 Loss 1171. The Special Study notes that fifteen bank securities were listed for trading on three of these exchanges. Special Study, pt. 3, at 36. 
The Commission's retention of authority under the antifraud and anti-manipulation provisions of the Exchange Act results in an area of concurrent jurisdiction with the federal banking agencies, since violations of section $12,13,14$ (a), 14 (c) or 16 could also constitute violations of the antifraud provisions. In those situations either a bank agency, for the purpose of enforcing section 12, 13,14 (a), 14 (c) or 16, or the Commission, in order to enforce the antifraud provisions under section 9,10 or 15 (c), could suspend trading under section 15 (c) (5) or 19 (a) (4); either could investigate, sue to enjoin, or transmit to the Attorney General evidence of violations of the respective sections. ${ }^{113}$

The Commission's memorandum to the House Subcommittee emphasizes that the powers vested in the federal banking agencies are "limited to those necessary to administer and enforce the provisions of the Act with respect to bank securities," and do not extend to the Commission's authority under section 19 to alter or supplement rules of national securities exchanges and to oversee their organization, administration and operation..$^{114}$ The exercise of these powers, the Commission indicated, would affect exchange trading in securities other than bank securities. ${ }^{115}$ By analogy, the federal banking agencies also have none of the Commission's powers over the rules, organization and administration of national associations of securities dealers registered with the Commission under section 15A.

The Commission's memorandum also indicates that the federal banking agencies would not have the Commission's power to suspend or expel members of a national securities exchange for violations of sections $12,13,14$ (a), 14 (c) and 16 with respect to bank securities, since that also would affect trading in other securities. ${ }^{110}$ The same conclusion follows with respect to the Commission's powers under sections $15(\mathrm{~b})$ and $15 \mathrm{~A}$ to discipline broker-dealers and their personnel. ${ }^{117}$ Thus, in the Commission's view which remains uncontradicted in the legislative history, section 12 (i) does not in any way permit the federal banking agencies to bar any person from participation in the securities industry because of violations of the provisions of the Exchange Act subject to their administration, even

${ }^{113}$ House Hearings, pt. 2, at 1364-67.

114 Id. at 1366 .

115 Ibid.

${ }^{110} I d$. at $1365-66$.

117 These powers and the extensive changes effected by the Amendments Act are discussed in Part $11 \mathrm{infra.}$ 
though it is arguable that such action is incident to their enforcement responsibilities.

Although the Senate Report made it clear that the federal banking agencies could adopt rules and forms different from those of the Commission whenever deemed appropriate, ${ }^{118}$ the House Committee, at the Comptroller's request, added an amendment to the Senate version of section 12 (i) to "underscore the committee's intention that the Commission's rules and interpretations of the law would not control" the banking agencies in the performance of their functions under the legislation. ${ }^{119}$ However, the proposed rules of the Federal Deposit Insurance Corporation and the Federal Reserve Board closely parallel the present regulations of the Commission under sections 12, 13, 14 and 16, and include the requirement that financial statements filed under the regulations be certified by independent public accountants. ${ }^{120}$ The proposed regulations also contain definitions of "held of record" which, with three exceptions, ${ }^{121}$ are similar to those proposed by the Commission.

It should be noted that the Commission's exemptive rules under section 16 do not apply to insider transactions in the securities of banks subject to the jurisdiction of a federal banking agency. Insiders of such banks with securities registered under section 12 must look to the exemptive rules of the administering bank agency. ${ }^{\mathbf{1 2 2}}$

\footnotetext{
${ }^{118}$ Senate Report 36. This point was constantly emphasized and re-emphasized throughout the congressional hearings. See, e.g., Senate Hearings 19-20, 54; House Hearings, pt. 1, at 118, 174; id., pt. 2, at 1363-64, 1369-70.

${ }^{110}$ HOUSE REPORT 8-9. The report notes that the amendment is "perhaps redundant." Id. at 9.

${ }^{120}$ Proposed FDIC Reg. $\S \S 335.1-335.7,29$ Fed. Reg. 12116-27, 13042-48 (1964); Proposed FRB Reg. $\$ \S$ 206.I-206.7, 29 Fed. Reg. 12127-39, 12926-31 (1964).

121 The proposed FDIC and the FRB regulations make no provision for including beneficial owners of securities held in the names of broker-dealers, banks and their nominees and securities held of record by co-owners are deemed held by a single person whether or not they have the same surname. The regulations provide in one instance that when $10 \%$ of a class of a security is held of record by any person, the record holders of that person's common stock shall be deemed the record holders of the security held by that person. See Proposed FDIC Reg. $\$ 335.2$ (k), 29 Fed. Reg. 12117 (1964); Proposed FRB Reg. $\$ 206.2$ (k), 29 Fed. Reg. 12128 (1964). For the Commission's proposed definition, see text accompanying notes 90-95 supra.

${ }^{123}$ The proposed regulations of the FDIC and the FRB contain a number of exemptions from $\S 16$ similar to those which have been provided by the Commission with respect to transactions in listed securities. They do not include, however, the exemptions afforded by the Commission under Rule $16 \mathrm{a}-4$ (b) relating to securities acquired and held for the account of an issuer, Rule $16 \mathrm{~b}-2$ relating to certain transactions effected in connection with a distribution, and Rules $16 \mathrm{~b}-7,16 \mathrm{~b}-8$ and $16 \mathrm{~b}-9$ relating to acquisitions and dispositions of securities pursuant to mergers or consolidations and certain exchanges of similar securities. See Proposed FDIC Reg. $\$ 335.6,29$ Fed. Reg. 13043 (1964); Proposed FRB Reg. $\S 206.6,29$ Fed. Reg. 12926 (1964). The
} 
The Comptroller of the Currency appears to have taken full advantage of his discretion under section 12 (i). His disclosure regulations for national and District of Columbia banks subject to section 12 (g) were adopted on August 21, 1964, one day after the Amendments Act was signed by the President. ${ }^{123}$ Primarily they represent modifications to amendments of his existing regulations proposed on June 10, 1964.124 The Comptroller's regulations vary in many respects from existing Commission rules under sections 12, 13 and 14, and provide for less extensive disclosures than do the Commission's rules relating to applications for registration of securities for trading on a national securities exchange and for proxy solicitation material with respect to such securities. ${ }^{125}$

In at least one respect, the Comptroller's revised regnlations give only token recognition to the Amendments Act. They provide that compliance with the annual reporting requirements of the regulations shall be deemed "a registration" under section 12 (g).120 These reporting requirements relate only to financial statements and do not require disclosure of other categories of information referred to in section 12 or in the Comptroller's regulations applicable to listed securities. ${ }^{127}$ This hardly seems to satisfy the principle enunciated in section 12 (g) that registration statements of over-the-counter com-

Comptroller's Regulations contain only one exemption from $\S 16-$ for acquisitions and dispositions of options or shares of stock acquired pursuant to certain stock option, stock purchase, bonus, profit-sharing, thrift, retirement, savings or similar plans. Comptroller's Reg. $\$ 12.5,29$ Fed. Reg. 12303 (1964). This exemption is broader than the exemption from $\$ 16$ (b) contained in the Commission's rules for acquisitions and dispositions of securities acquired pursuant to stock option and other plans. See SEC Sccurities Excli. Act Rule 16b-3, 17 C.F.R. $\$ 240.16 b-3$ (1964); SEC Securities Exch. Act Rule 16b-6, 17 C.F.R. $\$ 240.16 \mathrm{~b}-6$ (1964).

${ }^{123} 29$ Fed. Reg. 12300-05 (1964).

12. 29 Fed. Reg. 7676-78 (1964).

${ }^{125}$ Comptroller's Reg. $\$ \S 11.1-11.6$, Schedules A, B, \& C, 29 Fed. Reg. 12801-03 (1964) (proxy solicitation); Comptroller's Reg. $\$ \S 16.1-16.11,29$ Fed. Reg. 12303.05 (1964) (registration). The regulations are applicable to all national banks required to register under $\S 12(\mathrm{~g})$, and also to public offerings of national bank securitics. Section 11.4 of the regulations, by requiring the filing of proxy solicitation matcrial with the Office of the Comptroller prior to use, meets a major Commission criticism regarding the previous regulations. Sce Senate Hearings 22, 398; House Hearings, pt. 1, at 118 .

${ }^{120}$ Sections 10.1 and 10.3 of the Comptroller's Regulations provide that annual re. ports shall contain, at a minimum, comparative balance sheets and comparative state. ments (disclosing net operating income after applicable federal taxes, net operating income per share and cash dividends paid per share for the fiscal year and the preceding fiscal year) and comparative reconciliations of capital accounts which sum. marize the changes in the capital accounts for the fiscal year and the preceding fiscal year. Of course, additional disclosures are required in proxy solicitation material.

${ }^{127}$ Comptrollex's Reg. $\S \S 16.1-16.11,29$ Fed. Reg. 12303-05 (1964). 
panies should contain information comparable to that required in an application for registration under section 12 (b). Nor do the Comptroller's regulations provide for the filing of semi-annual or current reports as required by the Commission's regulations under section 13 and by those proposed by the Federal Deposit Insurance Corporation and the Federal Reserve Board. ${ }^{128}$

\section{Exemptions from Registration}

Express statutory exemptions from section 12 (g), but not from section 12(b) or 15(d), are contained in sections $12(\mathrm{~g})(\mathrm{l})$ and $12(\mathrm{~g})(2)$. Moreover, the Commission is empowered to grant additional exemptions under sections $12(\mathrm{~g})(3)$ and $12(\mathrm{~h})$. Section $12(\mathrm{~g})(\mathrm{l})$ exempts from registration any class of equity security which is an "exempted security" as defined in section 3 (a) (12) of the Exchange Act. An "exempted security" includes direct obligations of, and obligations guaranteed by, the United States or any state or political subdivision thereof, and such other securities as the Commission may by rule or regulation exempt from any one or more provisions of the act which by their terms do not apply to an exempted security. There are two rules presently in effect which were adopted pursuant to this authority. ${ }^{129}$

Paragraphs (A) and (B) of section 12 (g) (2) exempt any security listed and registered on a national securities exchange and any security issued by an investment company registered under the Investment Company Act. There is no exemption for a security enjoying unlisted trading privileges on an exchange unless it is listed on another exchange. In addition, issuers of a listed security will be required to register other unlisted securities meeting the criteria of section $12(\mathrm{~g})(\mathrm{l})$, and although registration of additional classes of securities will not result in additional section 13 duties, it will extend the application of sections 14 and 16.

Paragraph (C) exempts any security (other than permanent stock, guaranty stock, permanent reserve stock, and similar certificates evidencing non-withdrawable capital) issued by a savings and loan association or similar institution, provided it is both supervised and examined by a state or federal authority having supervision over the institution. The proviso indicates that more than an assertion of

\footnotetext{
${ }^{128}$ See note 120 supra.

${ }^{120}$ SEC Securities Exch. Act Rule 3a12-2, 17 C.F.R. § 240.3a12-2 (1964); SEC Securitics Exch. Act Rule 3a12-3, 17 C.F.R. $\$ 240.3 a 12-3$ (1964).
} 
regulatory jurisdiction is required, because the exemption is conditioned on actual supervision and examination by a state or the federal government. Since the exemption does not include capital stock, it is significantly more limited than the exemption for securities of savings and loan associations and similar institutions contained in section 3 (a) (5) of the Securities Act. ${ }^{130}$

Paragraph (D) exempts securities of issuers organized and operated exclusively for religious, educational, benevolent, fraternal, charitable or reformatory purposes and not for pecuniary profit in language substantially identical to that contained in section $3(4)$ of the Securities Act. 131

Paragraph (E) of the Senate version of section 12 (g) (2) exempted any security of a foreign issuer and certificates of deposit for such securities, with power in the Commission to revoke the exemption upon findings that a substantial United States market exists in the securities of such an issuer or class of issuers and that a continued exemption would not be in the public interest or consistent with the protection of investors. ${ }^{132}$ The House Committee eliminated this statutory exemption but provided in section $12(\mathrm{~g})(3)$ that the Commission may exempt foreign securities and certificates of deposit for such securities upon findings that such action is consistent with the public interest and the protection of investors. ${ }^{133}$

The House Committee also added three more statutory exemptions to section $12(\mathrm{~g})(2)$. Paragraph (E) exempts any security issued by a cooperative association as defined in section 15 (a) of the Agricultural Marketing Act of 1929,134 or a federation of such as-

${ }^{130}$ Section 3 (a) (5) of the Securities Act applies to "any security issued by a building and loan association, homestead association, savings and loan association, or similar institution, substantially all the business of which is confined to the making of loans to members." The $\S 12(\mathrm{~g})(2)(\mathrm{C})$ exemption substitutes a governmental supervision test for the business confinement test. The savings and loan industry did not oppose the exclusion of capital stock from $\S 12(\mathrm{~g})(2)(\mathrm{C})$. The United States Savings \& Loan League did propose that $\S 3$ (a) (5) of the Securities Act be amended to climinate the business confinement test. Senate Hearings $256-57$.

${ }_{131}$ The $\$ 3(4)$ exemption is not available where the promoters and organizers are entitled to receive a portion of the proceeds from the offering. See SEG $v$. American Foundation for Advanced Educ., 222 F. Supp. 828 (W.D. La. 1963); SEC v. Children's Hosp., 214 F. Supp. 883 (D. Ariz. 1963).

${ }_{132}$ Senate Hearings 320-21; SenAte REPORT 29-31. H.R. 6789 and H.R. 6793, as introduced, contained identical language. House Hearings, pt. 1, at 45 .

${ }_{133}$ HOUSE REPORT 11.

184 46 Stat. 18 (1929), as amended, 12 U.S.C. $§ 1141$ j (a) (1958). That section defines a cooperative association so as to require, among other things, that the association be operated for the mutual benefit of its producing or purchasing member farmers, that its volume of business with nonmembers be no greater than its volume with 
sociations which possess no greater powers or purposes than the cooperative associations so defined. Paragraph (F) exempts securities issued by a mutual or cooperative organization which supplies a commodity or service primarily for the benefit of its members and does not operate for pecuniary profit, provided the securities are issuable only to its customers and transferable only to their successors in interest or occupancy of the premises served or to be served by the issuer, and provided further that no dividends are payable to the security holders. These two exemptions were added at the behest of the National Council of Farmer Cooperatives and the National Rural Electric Cooperative Association, ${ }^{135}$ although the Commission had already indicated that those securities probably are not equity securities within the meaning of section $12(\mathrm{~g})$ and that if they were, an exemption would be provided. ${ }^{136}$

Most important of all, in paragraph (G) of section 12 (g) (2) the House Committee provided an exemption for any security issued by an insurance company, provided that the insurance company is regulated by its domiciliary state with respect to the filing of annual statements, proxies and insider trading. The adoption of this exemption represents a compromise of the most sharply disputed issue arising during congressional consideration of the Amendments Act.

Section $12(\mathrm{~g})$ is not clear and the legislative history is silent on whether eligibility for the section 12 (g) (2) exemptions is to be determined as of the last day of the issuer's fiscal year-the date as of which the asset and shareholder tests are measured. This result would seem to be indicated by section $12(\mathrm{~g})$, which requires that a registration statement be filed within 120 days after that date. Otherwise an issuer which lost an exemption on a later date often could not possibly comply with section $12(\mathrm{~g}) .^{137}$

members, and that either each member be limited to not more than one vote due to ownership of stock or membersbip capital or that the association not pay dividends on stock or membership capital in excess of $8 \%$ per annum.

${ }^{130}$ House Hearings, pt. 1, at 273-76; id., pt. 2, at 855-65, 1411-12.

${ }^{130}$ House REPORT 11; House Hearings, pt. 1, at 273-76, 332-33; id., pt. 2, at 855-65.

${ }^{137}$ If this is the correct interpretation, then loss of an exemption, say, one day after the year end would have no immediate effect. The issuer would not become subject to registration under $\S 12$ (g) until 120 days after the end of the year in which the exemption is lost, and would become subject at that time only if on the last day of that year the $\$ 12$ (g) criteria are met. The Commission has implicitly taken this position in its release announcing the adoption of Rule 12g3-1, which provides a temporary exemption from $\S 12(\mathrm{~g})$ until November 30 , 1965, for securities of foreign issuers and certificates of deposit or other evidences of interest relating to them. The release 
Finally, section $12(\mathrm{~h})$ provides that the Commission may exempt, in whole or in part, conditionally or unconditionally: (1) any issuer or class of issuers from section 12 (g), 13, 14 or 15 (d); and (2) any officer, director, or beneficial owner of any securities of an issuer from the provisions of section 16 if such issuer is required to register any security under section $12(\mathrm{~g})$. Section $12(\mathrm{~h})$ also allows the Commission, for purposes of sections $12(\mathrm{~g}), 13,14,15(\mathrm{~d})$ and 16 , to classify issuers and prescribe requirements appropriate for each class. The Commission may act by order (upon application of an interested person after notice and opportunity for hearing) or by rules and regulations.

Section 12 (h) thus seems to provide the Commission with authority to exempt issuers of listed securities from sections 13 and 14, and to exempt insiders of listed companies from section 16 if the company is required to have any security registered under section $12(\mathrm{~g})$. The legislative history does not negate this conclusion. ${ }^{135}$ Despite the broad grant of exemptive power, however, section $12(\mathrm{~h})$ adds to the Commission's existing authority to administer flexibly the provisions of sections $12(\mathrm{~g}), 13,14,15$ (d) and 16 in only three significant respects. ${ }^{139}$ First, it expressly permits the Commission to act by order on a case-by-case basis rather than only by rule or regulation. ${ }^{\mathbf{1 4 0}}$ Second, it makes it clear that the Commission has broad

states that "under Rule 12g3-1, the earliest date on which a foreign issuer could be required to register will be 120 days after its first fiscal year end following November 30 , 1965." SEC Securities Exch. Act Release No. 7427, Sept. 15, 1964. Where an issuer of a listed security that meets the registration criteria of $\$ 12(\mathrm{~g})$ wisbes to delist, it might be appropriate for the Commission to use its $\S 12$ (d) powers to condition delisting upon simultaneous or prior registration under $\S 12(\mathrm{~g})$. This would prevent the hiatus that would otherwise result.

${ }^{138}$ Section $12(\mathrm{~h})$ is specifically referred to in connection with issuers of over-thecounter securities but not issuers of listed securities. See, e.g., SENATE REPort 63; Senate Hearings 355; House Hearings, pt. 1, at 216. Cf. House RePoRr 17 which gives the widest possible reading to the section, even stating that it empowers the Commission to exempt "any person" from $\$ 16$.

${ }^{139}$ Section $3($ a) (12) authorizes the Commission to define any security as an "exempted security" and to exclude such securities from the operation of any section which by its terms does not apply to an exempted security. These sections include $\$ \S 7$ (a), 7 (c) (1), 9, 11 (d), 12 (a), 12 (g), 14 (a) and 16. The Commission also has specific authority to exempt any transaction from $16(\mathrm{~b})$ which is not within the purposes of this section. In addition, $\S \S 12,13,14,15$ (d) and 23 (a) provide the Commission with broad discretion in prescribing the form and content of applications for registration, registration state. ments, periodic reports, and proxy solicitation material.

${ }^{140}$ All of the exemptive provisions contained in the Exchange Act prior to the Amendments Act provided that the Commission could act by rule or regulation. But the Commission has issued at least one rule providing for the filing of an application for an exemption and for approval of the application after notice and opportunity 
exemptive authority for purposes of section 15 (d). ${ }^{141}$ Third, it broadens to some extent the Commission's pre-existing exemptive power under section 16. ${ }^{142}$ Perhaps of greater significance is the fact that section $12(\mathrm{~h})$, which was initially recommended by the Commission and accepted without change by Congress, reflects a recognition that it may be necessary to administer the Exchange Act with respect to over-the-counter securities more flexibly than has been necessary for listed securities.

\section{a. Insurance Companies}

The House Committee amendment ${ }^{143}$ adding paragraph (G) to section 12 (g) (2) exempts any security issued by an insurance company from the registration requirements of section $12(\mathrm{~g})$ (and thus also from sections 13,14 and 16) only if the company is regulated by its domiciliary state in all three of the following respects:

1. The insurance company must be required to, and must in fact, file an annual statement with the state insurance commissioner. This statement must either conform to that prescribed by the National Association of Insurance Commissioners ${ }^{144}$ (NAIC), or in the de-

for hearing if it appears that a hearing is necessary or appropriate. SEC Securities Exch. Act Rule 15d-20, 17 C.F.R. \$ 240.15d-20 (1964). There seems to be no reason why the Commission should not be able to adapt its rulemaking powers in this fashion. In any event, the power to proceed on a case-by-case basis is now made clear by $\S 12(\mathrm{~h})$.

${ }_{1} \$ 2$ Some doubt may have been created as to the scope of the Commission's power to exempt securities not comprehended within the purpose of $\S 15$ (d) by Greene v. Dietz, 247 F.2d 689 (2d Cir. 1957). There the court narrowly construed the comparable exemptive power contained in $\$ 16$ (b) and expressed doubt as to the validity of the existing provisions of Rule $16 \mathrm{~b}-3$. The rule has since been amended. See SEC Securities Exch. Act Release No. 6275, May 26, 1960.

${ }^{142}$ The doubts expressed by the court in Greene v. Dietz, supra note 141, have been considered dicta and not followed in the lower courts. See cases cited 2 Loss 1117 n.309. It still stands, however, as the view of the court most important to the administration of the federal securities laws. Although the provisions of Rule $16 \mathrm{~b}-3$ considered by the court in Greene were adopted under the broader exemptive authority of $\S 3(\mathrm{a})(12)$, as well as pursuant to that contained in $\S 16(\mathrm{~b})$, see SEC Securities Exch. Act Release No. 4754, Sept. 24, 1952; SEC Securities Exch. Act Release No. 5312, May 21, 1956, this fact is not discussed in the court's opinion. It could be argued that this general exemptive authority cannot be used to avoid the limitations of the specific exemptive authority of $\S 16(\mathrm{~b})$. But this argument would not apply to $\S 12$ (h), which was enacted to provide adequate authority to administer flexibly $\$ 16$ with respect to insiders of issuers of securities required to be registered under $\S 12(\mathrm{~g})$.

${ }^{143}$ See House REPORT 9-11. The insurance exemption was first added by the House Subcommittee print. The House Committee materially altered that version of the exemption.

14: The NAIC is a voluntary organization composed of the insurance regulatory authorities of the fifty states, the District of Columbia, and United States territories, as well as those of Canada and the Philippines. Its purpose is to encourage uniformity 
termination of the state commissioner substantially conform to that prescribed by the NAIC.

2. The insurance company must, in respect of its securities, be subject to proxy regulation which conforms to that prescribed by the NAIC.

3. After July 1, 1966, purchases and sales of the insurance company's securities by its officers, directors and beneficial holders must be subject to regulation in substantially the same manner as that provided in section 16 of the Exchange Act.

Presumably, "domiciliary state" means the state of incorporation rather than the state in which the insurance company maintains its principal place of business or conducts the most substantial portion of its business. The exemption does not extend to companies with securities listed and registered for trading on a national securities exchange, nor does it relieve a company from the duty to file periodic reports pursuant to amended section $15(\mathrm{~d})$. The exemption is unavailable for foreign insurance companies and does not cover insurance holding companies. The legislative history indicates that section $12(\mathrm{~g})(1)$ has no applicability to mutual insurance companies. ${ }^{145}$ An "insurance company" is defined under new section 3 (a) (19) of the Exchange Act as

a company which is organized as an insurance company, whose primary and predominant business activity is the writing of insurance or the reinsuring of risks underwritten by insurance companies, and which is subject to supervision by the insurance commissioner or a similar official or agency of a State; or any receiver or similar official or any liquidating agent for such a company, in his capacity as such. ${ }^{140}$

The primary and predominant business activity test could make the exemption unavailable for some companies which are regulated as insurance companies under state law.

in state insurance regulation, and it has formulated convention form annual state. ments for fire, casualty, life, accident, and health companies. HOUSE REPORT 10; House Hearings, pt. 2, at 868 .

${ }^{148}$ Foreign companies (with the possible exception of those in the Philippine Islands) have no "domiciliary state."

During the Senate hearings there was a proposal that if insurance companies were exempted, insurance holding companies should also be exempted. Senate Hearings I63-65. Such an exemption was not provided. Regarding mutual companies, sec Senate Report 36; House Report 9; Senate Hearings 23, 355; House Hearings, pt. 1, at $82,119,215$.

${ }^{160}$ Investment Company Act of 1940 \& 2 (a) (17), 54 Stat. 793 (1940), 15 U.S.C. $\S 80 \mathrm{a}-2$ (17) (1958). Section 3 (a) (19) provides that the term "insurance company" shall have the same meaning as that given the term in the Investment Company Act. 
Throughout the congressional hearings the Commission, in accordance with the recommendations of the Special Study, ${ }^{147}$ vigorously opposed any exemption for insurance company securities on the ground that state insurance regulation was oriented toward the protection of policyholders and, like federal and state banking regulation, had failed to satisfy the need for the investor protections of the Exchange Act. ${ }^{148}$ The Commission's position was buttressed by the findings of the Special Study, which confirmed the findings of earlier Commission studies as to serious inadequacies in insurance company financial reports and proxy material furnished to shareholders. ${ }^{149}$ The Commission also pointed to the large number of enforcement actions against fraudulent sales of insurance company securities. ${ }^{150}$ On the basis of these arguments the Senate Committee provided no exemption for insurance company securities, ${ }^{151}$ and the bill passed the Senate without change against opposition from the industry.

During the interval between the Senate hearings and the vote by the House Committee, two events of crucial importance occurred. First, the NAIC adopted a stockholder information supplement as part of its annual reporting form ${ }^{152}$ and recommended the adoption by state legislatures of a model insider trading statute with respect to insurance company securities patterned after section 16 of the Exchange Act. Second, industry opposition intensified and was supported by the NAIC, ${ }^{153}$ whose representatives acknowledged some validity to the Special Study's criticisms of insurance company disclosures, but pointed to their recent efforts to remedy these inade-

\footnotetext{
${ }^{147}$ Speeial Study, pt. 3, at 40-42. There is no exemption for securities of insurance companies under the Securities Act or $\$ 12$ (a) of the Exchange Act. As of June 30, 1963, 169 insurance companies were subject to reporting requirements under $\S 15$ (d), and the securities of two other companies were listed on exchanges. House Hearings, pt. 1, at 176 n.5.

${ }^{148}$ Sec, e.g., Senate Hearings 23-30, 398-99; House Hearings, pt. 1, at 82-95, 119-22, $175-80$; $i d .$, pt. 2 , at 1203-15, 1271-83.

${ }^{140}$ Special Study, pt. 3, at 40-41. See also the supplemental study conducted by the Commission's Division of Corporation Finance. House Hearings, pt. 2, at 1209-12.

${ }^{150}$ Senate Hearings 25-26, 288-90, 302-07; House Hearings, pt. 1, at 84, 120, 176-77, 185-86, 199-204.

161 SENATE REPORT 36-38.

${ }^{162}$ House Hearings, pt. 2, at 874-78.

${ }^{153} \mathrm{Id}$. at 868-923. The NAIC did not appear at the Senate hearings. Commissioner Stafford Grady of California explained that the bill was passed in the Senate before a NAIC committee, which had been appointed to study the criticisms of the Special Study and the provisions of the bill, had been able to complete its recommendations. Id. at 870 .
} 
quacies and argued that the tradition of state rather than federal regulation of insurance companies should be preserved at least until the states had been given an opportunity to develop an adequate regulatory program for the protection of insurance company shareholders. ${ }^{154}$ The conditions attached to the section 12 (g) (2) (G) exemption reflect a congressional attempt to insure performance of the NAIC undertaking given to the House Subcommittee.

Section $12(g)(2)(G)$ and its legislative history are vague in some respects as to the nature and extent of regulation that must be provided by the domiciliary state. It is clear that state regulation need not be equivalent in every respect to that which would be provided by the Commission under the Exchange Act, but there is uncertainty over the extent of permissible deviation.

Paragraph (G) (i) seems reasonably clear. It requires the filing of an annual statement with the state insurance commissioner which, in the determination of the commissioner, substantially conforms to that prescribed by the NAIC. Since the NAIC convention form annual statement is used by the insurance regulatory authorities of all fifty states, ${ }^{155}$ this requirement in and of itself effects no change in the present reporting practices of insurance companies. ${ }^{150}$ The annual statement must not only be required; it must actually be filed. Since the determination of substantial conformity is to be made by the state insurance commissioner, insurance companies may have considerable protection against loss of the exemption because of inaccurate or incomplete statements. The exemption, however, would be lost if the discrepancies in a statement exceed the tolerances permitted by the substantial conformity test. This test literally seems to

\footnotetext{
${ }^{154}$ Id. at 868-923.

${ }^{156}$ House REPORT 10; House Hearings, pt. 2, at 869.

${ }^{168}$ The major criticism of the Special Study with respect to the financial state. ments filed with state insurance authorities was that they were too voluminous and complex for use by investors. Special Study, pt. 3, at 40. Although the Commission's accounting regulations generally provide for a simpler presentation of financial data, it has accepted, and it indicated that it would continue to accept, for purposes of $\$ \S 12$ and 13, the annual statements filed with state authorities together with brief explanatory notes for life insurance company statements and a supplementary reconciliation of income and surplus statements in statements filed by fire and casualty companies. Unhike Securities Act registration statements filed by insurance companies, certified financial statements have not been required in Exchange Act filings. SENATE Rerort 48-49; House Hearings, pt. 1, at 84-85, 88-89, 120-21, 177-78; id., pt. 2, at 1053-55, 1207-08, 1271-83. The Senate Report expressly noted that the Commission's requirements under the Exchange Act do not effect a basic modification of life insurance company accounting procedures and that it expected the Commission to continuc this practice. Senate Report 38.
} 
apply only to the form and content of the statement; a late filing might cause a loss of the exemption only if the statement were not filed by the last day of the company's fiscal year, since eligibility for the exemption will probably be determined as of that date.

Non-compliance with state proxy or insider trading regulation may not affect an insurance company's eligibility for the exemption, since paragraphs (G) (ii) and (G) (iii) require only that the company be subject to such regulation. Paragraph $(G)$ (ii), however, raises a more basic question-what kind of state proxy regulation is necessary? The state proxy regulation referred to by the NAIC and individual state insurance commissioners during the House hearings consisted of the requirement that insurance companies complete the stockholder information supplement to the NAIC convention form annual statement, stating whether, among other things, the company has afforded shareholders an opportunity to vote for or against the election of directors and other matters presented for vote at any stockholders' meeting, and whether specified financial and other information has been and is to be furnished to stockholders. ${ }^{157}$ Although the supplement is only in questionnaire form, the NAIC argued that it would have the same effect as mandatory requirements because of the fact that insurance companies would want to answer the questions affirmatively in view of the broad powers of the state insurance commissioners over their business. ${ }^{158}$

The House Report describes the NAIC's proposals in considerable detail and seems to accept the stockholder information supplement as a satisfactory substitute for Commission regulation under sections 13 and $14 . .^{159}$ However, paragraph (G) (ii) must necessarily require something more in the way of state proxy regulation. Otherwise it would be entirely superfluous, since insurance companies are required to file the stockholder information supplement as part of the annual statement pursuant to paragraph (G) (i).$^{160}$ But this does not necessarily mean that paragraph (G) (ii) can be satisfied only by proxy regulation in the manner provided by section 14 of the Ex-

\footnotetext{
${ }^{157}$ House Hearings, pt. 2, at 876-79.

${ }^{158}$ Id. at $872-73,882-84$.

${ }^{109}$ House RePORT 10. The report states that the purpose of the supplement is to elicit information whether stockholders have been furnished "information substantially" equivalent to that which the Commission would require under [sections 13 and 14] ...," ibid., but in some respects, the questions do not cover disclosures required by the Commission. See House Hearings, pt. 2, at 1213-15.

${ }^{200}$ House REPORT 10; House Hearings, pt. 2, at 872.
} 
change Act, since this would require legislation in many of the states and, unlike the insider trading regulation provided in paragraph (G) (iii), there is no suggestion in the legislative history that the regulation contemplated under paragraph (G) (ii) would necessarily require additional state legislation. ${ }^{101}$ Unlike paragraph (G) (iii), which does not apply until July 1, 1966, paragraph (G) (ii) does not allow time for legislation. Perhaps, the answer is that paragraph (G) (ii) is designed to meet the criticism of the NAIC's proposal made by William L. Cary, then Chairman of the Commission, that

If any State insurance commissioner should let it become known that he did not particularly care whether the questionnaire was answered in the affirmative or in the negative, the disclosure scheme would probably collapse in that State. In this connection, it should be remembered that, prior to the introduction of this bill, State insurance commissioners generally did not seem to be much interested in disclosure to stockholders. ${ }^{162}$

Thus, paragraph (G) (ii) could mean that the proxy solicitation practices referred to in the stockholder information supplement are, in effect, mandatory requirements, and that to retain the section 12 (g) (2) (G) exemption for insurance companies within their jurisdiction, state insurance commissioners must make a vigorous effort to insure compliance with these mandates. On the other hand, the word "regulation" strongly implies that mandatory, legal requirements by rule or statute are contemplated; and the NAIC did not maintain that state regulators now have sufficient authority to impose such requirements by rule. To resolve this uncertainty the NAIC might prepare and advocate the passage of a model proxy statute at the same time that the insider trading statutes are passed. In light of the possibility that sections 13,14 and 16 (and the express liabilities and implied rights of action thereunder) might be held applicable to an issuer required to be, but not, registered, the present uncertainty might be regarded as serious enough to warrant that action.

One further problem is raised by paragraph (G) (ii). That provision refers to regulation "of proxies, consents, or authorizations in

101 The State insurance commissioners made it clear that state regulation comparable to that provided by $\S 16$ would require legislation, but that the proxy regulation contemplated by them did not. House Hearings, pt. 2, at 920-22. The House Report states that compliance with the reporting and proxy conditions "can be done through State administrative action." HOUSE REPORT 17.

${ }^{162}$ House Hearings, pt. 2, at 1214-15. 
respect of securities" issued by an insurance company. Does this require proxy "regulation" with respect to all outstanding securities?103

Although paragraph (G) (iii) requires only that insider trading in the securities of insurance companies be subject to regulation "substantially in the manner provided in section 16," the NAIC has recommended for this purpose adoption of a model insider trading statute which is virtually identical to section $16 .^{164}$ The statute, similar to section $16(\mathrm{~b})$, provides that the profit recovery provisions shall not apply to "any transaction or transactions which the Insurance Commissioner may by rules and regulations exempt as not comprehended within the purpose of this paragraph." 105 The substantially similar provision will permit some differences between the exemptive rules under section 16 adopted by the state commissioners and the Commission, as well as some differences that may develop between the decisions of the federal courts and the various state courts.

Paragraph (G) (iii) speaks of regulation of "securities issued by such insurance company." Does this mean that all securities, all equity securities, some securities, those equity securities which but for paragraph (G) would be subject to registration under section $12(\mathrm{~g})$, or all "stock" (the provision in the model statute) must be "subject to regulation substantially in the manner provided in section 16 "? Interestingly, the model statute does not contain the marketmakers' exemption of section 16 (d), added to the Exchange Act by the Amendments Act. It is questionable whether the exemptive authority of the model statute could be exercised for this purpose..$^{166}$

There may be questions raised as to the enforcement of the state insider trading statutes in the courts of another state. Since the profit recovery provisions of section $16(\mathrm{~b})$ are not penal sanctions (despite some early authority to the contrary) ${ }^{107}$ and will reflect the policy of virtually all, if not all, of the fifty states, it seems likely that both original suits and actions to enforce judgments could be brought

\footnotetext{
${ }^{203}$ Note also the use of "or," when seemingly "and" should have been used. Because of the legislative history, however, it is clear that regulation of, say, consents alone would not suffice.

104 House Hearings, pt. 2, at 920-23.

${ }^{105} I d$. at 922.

${ }_{100}$ With respect to the scope of the same exemptive authority in $\S 16(\mathrm{~b})$, see note 142 supra.

107 See 2 Loss 1084.87 (1961, Supp. 1962).
} 
in the courts of a foreign state. ${ }^{168}$ State insurance commissioners would seem to have little need to go outside the state to enforce the reporting requirements and prohibitions against short sales and "sales against the box" against officers and directors. The more troublesome questions may be those involving the jurisdiction of a foreign court to entertain an injunctive action against a ten per cent holder, and whether state insurance commissioners have authority to bring such actions in foreign courts. ${ }^{169}$

Both the model state insider trading statute and section 16 apply to securities of listed insurance companies, and presumably to those of companies which are regulated as insurance companies under state law but are not "insurance companies" within the meaning of new section 3 (a) (19), as well as to companies which may be ineligible for the section $12(\mathrm{~g})(2)(G)$ exemption because of a failure to satisfy paragraph (G) (i) or (G) (ii). Theoretically, it is possible that insiders of such companies will be subject to double liability for short term trading profits. However, both the state and federal causes of action inure to the benefit of the insurance company even though they might be instituted by different shareholders, and it seems unlikely that the courts will permit collection of two judgments in suits based on the same transactions. Section 28 (a) of the Exchange Act might also afford protection. ${ }^{170}$

\section{b. Foreign Securities}

Section $12(\mathrm{~g})$, as amended by the House Committee, subjects securities of foreign issuers and certificates of deposit for such securities to the registration requirements to the same extent as other securities traded in the over-the-counter market. However, section 12 (g) (3) specifically empowers the Commission to exempt any foreign security or certificate of deposit for such a security upon findings that such action is in the public interest and consistent with the protection of investors. The Commission could act by rule or regulation

\footnotetext{
${ }^{188}$ See Stumberg, Principles of Conflict of Laws 171-73 (3d ed. 1963); cf. Loss \& Cowetr, Blue Sky Law 194-97 (1958).

${ }^{100}$ The model insider trading statute does not provide for enforcement by state insurance commissioners. House Hearings, pt. 2, at 921-22. Presumably, it could bc enforced in the courts pursuant to relevant provisions of the state insurance codes.

${ }^{170}$ Section 28 (a) provides that the rights and remedies provided by the act are in addition to any other rights and remedies that may exist at law or in equity, but that no person may recover through satisfaction of judgment more than the amount of his actual damages on account of the act complained of. Are profits recoverable under $\S 16$ (b) "damages" with the meaning of $\S 28(\mathrm{a})$ ?
} 
or by order after notice and opportunity for hearing. The Senate bill provided a statutory exemption with power in the Commission to revoke. ${ }^{171}$ The elimination of this express exemption by the House Committee caused widespread consternation among foreign security dealers, apparently on the misconception that it would be illegal to trade in the securities of an issuer failing to register under section 12 (g) as required. ${ }^{172}$ Nothing in the Amendments Act leads to this conclusion with respect to either foreign or domestic securities, and the House Report carefully states that non-compliance by a foreign issuer "will not, of itself, mean that trading in the United States of the securities of such issuer will be illegal, or for that reason give rise to civil liabilities on the broker-dealers trading in such securities." 173 The preference of the Commission and the securities industry for the Senate version reflected the apprehension that broker-dealers might be reluctant to trade in securities of issuers which ignore the requirements of the Exchange Act.174

Under both the Senate version and the final bill, questions of coverage with respect to foreign securities are left almost entirely to the discretion of the Commission. The effect of the House amendment is procedural; in subjecting foreign issuers to the Exchange Act the Commission does not have the burden of finding, as it would have had under the Senate version, that a substantial United States market exists for the securities. ${ }^{175}$ In any event, the initial result has been the same, since the Commission has granted a blanket exemption from section $12(\mathrm{~g})$ until November 30, 1965, for all securities issued by foreign governments, nationals, and corporations and certificates of deposit or other evidences of interest relating to such securities. ${ }^{176}$ Thus, no foreign issuer will be required to file a registration statement until 120 days after the end of its first fiscal year following November 30, 1965. The exemption does not extend to reporting obligations pursuant to section 15 (d).

Section 3 (a) (17) of the Exchange Act includes as "interstate commerce" any trade, commerce, transportation or communication between any foreign country and any state. In view of this definition

\footnotetext{
${ }^{171}$ Senate Report 29-31, 62.

${ }^{172}$ See N.Y. Times, Aug. 6, 1964, p. 37, col. I; id., July 4, 1964, p. 12, col. I; id., May 23, 1964, p. 22, col. 4; id., May 20, 1964, p. 59, col. 1; id., May 12, 1964, p. 36, col. 1; Wall Street Journal, May 11, 1964, p. 26, col. 2.

173 HOUSE REPORT 11.

174 SENATE RePORT 29.30; House Hearings, pt. 2, at 1288.

176 HOUSE, REPORT 11.

${ }^{170}$ See Securities Exch. Act Release No. 7427, Sept. 15, 1964.
} 
and the broad exercise of the federal commerce power reflected in section 12 (g), that section literally applies not only to the equity securities of all foreign issuers meeting the asset and shareholder tests which do business in the United States, but also to those of issuers which are engaged in trade with the United States or in a business affecting trade with the United States. The fact that such issuers do no business in the United States, that they have no securities held by residents of the United States and that there is no substantial market in the United States for their securities seems immaterial under the literal terms of the statute.

Obviously, the Commission's exemptive authority should be utilized to eliminate from the broad sweep of section $12(\mathrm{~g})$ foreign securities which have no substantial United States market and which are not held by a substantial body of United States residents. There are, however, major problems in measuring the number of United States security holders and the extent of the over-the-counter market for securities of foreign issuers. The Senate Committee rejected a suggestion that the Commission be prohibited from revoking the statutory exemption in the Senate version of the bill unless it found that there were at least 500 registered owners resident within the United States; it did so on the ground that foreign securities are sometimes issued in bearer form and that a residence requirement would "add undue complexities" to the administration of the bill.177 Nevertheless, a shareholder test based on United States residence may prove workable with respect to securities of foreign issuers which make their records of security holders available to the Commission and with respect to American Depositary Receipts (ADR's) which, in most instances, are issued in registered form by United States banks against deposits of the underlying foreign securities. ${ }^{178}$ There seemingly would be little difficulty in determining the number of ADR's held of record by United States residents by reference to the books kept by the issuing banks. However, it will be difficult to determine the residence of record holders of registered shares of foreign

\footnotetext{
177 SENATE REPORT 30.

${ }^{178}$ ADR's are issued in the names of the depositors or holders and are transferable within the United States in the same manner as domestic securities. They obviate problems pertaining to time, cost and risk involved in the transfer of the underlying shares. They also serve, in some instances, to avoid foreign currency exchange controls and the imposition of foreign transfer and death taxes. See SENATE REPORT 29; Cohen 8. Throop, Investment of Private Capital in Foreign Securities, in A LAwYER's GuIDE To International Business Transactions (Surrey ed. 1963).
} 
issuers which do not cooperate with the Commission, ${ }^{179}$ and virtually impossible to make such a determination with respect to securities issued in bearer form. In determining whether to exempt these securities from section $12(\mathrm{~g})$, the Commission presumably will have to rely primarily on expressions of trading interest in the United States market as evidenced by the published quotations of brokerdealers and their records of actual transactions. ${ }^{180}$

In some significant respects, the Commission's disclosure requirements under sections 12 and 13 conflict with financial practices and business traditions in various foreign countries, and the proxy rules and the insider trading provisions of sections 14 and 16 represent an even wider departure from such practices and traditions. ${ }^{181}$ To avoid interference with established trading markets and to encourage voluntary compliance, the Commission has met this problem by modifying and simplifying the disclosure requirements under sections 12 and 13 for listed securities of foreign issuers, ${ }^{182}$ and by exempting such securities from sections 14 and 16, except in the case of those issued by North American and Cuban issuers. ${ }^{183}$ Over-the-counter issuers, unlike issuers of listed securities, which must execute

\footnotetext{
170 The Commission must still show that a foreign issuer meets the shareholder and other coverage criteria of $\S 12(\mathrm{~g})$ before "requiring" registration. In some instances this information may be available from published material.

${ }^{130}$ There are no published figures indicating the number of foreign issuers with securities traded in the United States market. On the basis of the data of the Special Study it can be estimated that the securities of as many as 1300 to 1400 foreign issuers were quoted by at least one dealer in the daily sheets of the National Quotation Bureau, Inc. during the last three months of 1961 . Special Study, pt. 3, at 19. A large portion of these were probably Canadian securities, which are generally issued in registered form, and probably less than 200 were represented by ADR's. See Cohen \& Throop, supra note 178, at 579 n.327, 581 n.333. Since United States banks usually issue ADR's whenever trading activity warrants, the problems of coverage under $\$ 12(\mathrm{~g})$ for foreign securities issued in bearer form may not be siguificant.

${ }^{181}$ See Cohen \& Throop, supra note 178, at 561-67. See also Stevenson, Legal Aspects of the Public Offering of Foreign Securities in the United States Market, 28 GEO. WASH. L. REv. 194 (1959).

${ }^{182}$ See SEC Securities Exch. Act Forms 18, 19, 20 \& 21, 17 C.F.R. $\$ \S 249.218-.221$ (1964); SEC Securities Exch. Act Forms 18-K, 19-K, 20-K \& 21-K, 17 C.F.R. $\$ \$ 249.318-.321$ (1964). These are the registration and annual reporting forms under $\$ \S 12(\mathrm{~b})$ and 13 for securities of foreigu issuers. All foreign issuers filing on these forms have been exempted from the requirement of filing current reports, SEC Securities Exch. Act Rule 13a-11, 17 C.F.R. $\S 240.13 a-11$ (1964), and all, except private North American and Cuban issuers, have been exempted from the requirement of filing semi-annual reports. SEC Securities Exch. Act Rule 13a-13 (b) (7), 17 C.F.R. $\$ 240.13 a-13$ (b) (7) (1964). Similar, but not identical, treatment is accorded foreign companies required to file reports under \& 15 (d). See SEC Securities Exch. Act Rule 15d-11 (b), 17 C.F.R. \$ 240.15d-11 (b) (1964); SEC Securities Exch. Act Rule 15d-13 (c) (7), 17 C.F.R. § 240.15d-. 13 (c) (7) (1964).
}

${ }_{183}$ SEC Securities Exch. Act Rule 3a12-3, 17 C.F.R. \$ 240.3a12-3 (1964). 
listing agreements with the exchanges and file applications for registration with the exchanges and the Commission, often have not initiated the United States market for their securities. ${ }^{184}$ Hence, the problem of enforcement against issuers of securities required to register under section $12(\mathrm{~g})$ may be more difficult than with respect to issuers of listed securities. Undoubtedly, however, foreign issuers which wish to make public offerings of their securities in the United States will be careful to comply with section 12 (g) and with whatever requirements are imposed under sections 13, 14 and 16.

During the legislative hearings the Commission pledged only to avoid interference with trading markets in over-the-counter securities of foreign issuers as it has done with respect to listed securities of such issuers. It did not commit itself to retain the existing pattern of exemptions for listed securities or to extend it to securities registered under section $12(\mathrm{~g}) .^{185}$

Even prior to the introduction of S. 1642, the Commission had proposed to rescind the exemption from sections 14 and 16 for listed securities of foreign issuers with significant United States connections. ${ }^{188}$ While the Commission has not adopted this rule, its attention may again be focused on this problem in connection with the application of sections 14 and 16 to over-the-counter securities of foreign issuers. It would seem entirely appropriate to apply the proxy rules, with such modifications as may be required by the laws of the countries of organization, to foreign companies which have a majority of a class of equity security owned by United States citizens or residents, and to extend the insider trading provisions to foreign securities which are primarily traded in the

\footnotetext{
${ }^{284}$ As a prerequisite for registration and listing on an exchange, a foreign issuer must not only voluntarily file an application for registration under $\S 12$ (b), but also must execute a listing agreement with the exchange which may contain disclosure and other requirements more demanding than those of the Commission. See Cohen \&: Throop, supra note 178, at 573-78, 582.

${ }^{185}$ See SENATE REPORT 30; House Hearings, pt. 1, at 179-80.

${ }^{280}$ Under the proposed modification to Rule $3 \mathrm{al2}-3$, the exemption would no longer be available to any of the following foreign securities: (1) voting trust certificates if the voting trustee or, if more than one, at least one-half of the trustecs, or any person controlling the trustee or trustees are United States citizens or residents; (2) securities of issuers which have their principal executive offices in the United Statcs if more than $25 \%$ of their consolidated total assets are located in the United States or more than $25 \%$ of their consolidated gross revenues are derived from United States sources; (3) securities of issuers with $50 \%$ of their consolidated total assets located in the United States or $50 \%$ of their consolidated gross revenues derived from United States sources; and (4) securities of issuers, a majority of whose dircctors are United States residents or citizens or a majority of whose voting stock is held of record by United States residents. SEC Securities Exch. Act Release No. 6912, Oct. 11, 1962.
} 
United States markets. In addition, consider companies which have a significant nexus with the United States in terms of operating assets located here or income derived from within this country, or which have offered, or offer, their securities to the American public. Even if they fit in neither of the two categories above, it would appear appropriate to apply to them, say, section 13, if not already applicable through section $15(\mathrm{~d})$, and the proxy rules, perhaps modified to require only that section 14 (c) statements be furnished American shareholders. This, of course, only suggests some of the relevant considerations and possible bases of classification. Because of the sweeping reach of section 12 (g), it might be appropriate in this regard to treat securities of North American issuers in a manner more comparable to those of other foreign issuers. ${ }^{187}$

Additional factors should be considered in connection with the application of section 12 (g) to ADR's. For purposes of the Securities Act, ADR's are considered a security separate from the underlying security and can only be issued pursuant to an effective registration statement. ${ }^{188}$ Since ADR's are frequently issued by United States banks acting independently of a depositary arrangement with the issuer of the underlying security, the disclosures made by the banks cannot be comparable to the information usually required in a Securities Act registration statement. Thus, in these situations the registration form for ADR's has been greatly simplified so that it consists largely of a short prospectus summarizing the terms of the depositary arrangement, and of undertakings to comply with section

\footnotetext{
${ }^{187}$ Presumably, the exclusion of North American issuers from the modified registration and reporting requirements and from the $\S 14$ (a) and $\S 16$ exemptions applicable to other foreign issuers reflects the widespread interest of United States investors and the continuing Commission enforcement problems with respect to these securities, particularly those of Canadian issuers. See Cohen \&. Throop, supra note 178, at 594-96; 17 SEC ANN. REP. 159-60 (1951).

${ }^{288}$ Senate RePort 29. Although the Commission had adopted Form C-3 for the registration of ADR's in 1937, it was seldom used because of the extensive information required concerning the issuer of the underlying securities, even though only the signature of the depositor and not that of the issuer was required if the underlying security was not also subject to registration. See Note, SEC Regulation of American Depositary Receipts: Disclosure, Ltd., 65 YALE L.J. 861 (1956). In 1955 the Commission adopted Form S-12 for the registration of ADR's issued against deposits of outstanding securities which are not themselves required to be registered. Under Form S-12 the required disclosures have been greatly simplified, and although the bank or other depositary signs the registration statement, the entity designated as the depositary arrangement, not the depositary, is expressly designated as the issuer for purposes of the form and the Securities Act, including civil liability under $\S$ il of the act. For the background and a critical view of the so-called "fictitious entity" theory, see ibid. On the other hand, this approach has been termed an "awe-inspiring (and altogether laudable) demonstration of administrative flexibility." I Loss 465.
} 
15 (d) and to make available to the Commission and to the ADR holders any shareholder communications furnished by the foreign issuers of the underlying security. ${ }^{189}$

As noted above the Commission's proposed definition of "held of record" would treat record holders of ADR's as record holders of the underlying security. ${ }^{190}$ This would require registration of any class of underlying security when the number of record holders of that security combined with the number of record holders of the $A D R$ 's is sufficient to meet the shareholder test, provided the issuer meets the other criteria of section $12(\mathrm{~g})$ and is ineligible for any exemption provided by the Commission. Registration of the ADR's, in addition to registration of the underlying security would serve only the very limited purpose of applying the proxy rules in those instances, which rarely if ever occur, where the issuer of the ADR's solicits the consent or authorization of the ADR holders. The disclosure function of section 14 as well as that of sections 12 and 13 with respect to the underlying securities could best be accomplished through registration of the underlying security. Furthermore, if the underlying security were registered, section 16 would probably apply to ADR transactions of officers and directors of the foreign issuer and ten per cent holders of both the ADR's and underlying security, whether or not the ADR's were also registered, since beneficial ownership of the ADR's constitutes beneficial ownership of the underlying security for purposes of section $16 .{ }^{101}$ Even in those situations where the issuer of the underlying security is the issuer of the ADR's, ${ }^{192}$ registration of both securities would not provide significant additional benefits. The Commission could, under the proxy rules-to the extent an exemption is not

${ }^{189}$ SEC Securities Act Form S-12, 17 C.F.R. $\$ 239.19$ (1964). The required disclosures, which are usually set forth on the back of the ADR certificate, consist of four items: (1) the identity of the depositary bank; (2) the fees and charges collected by it; (3) the terms of the deposit; and (4) the undertaking to make available shareholder communications issued by the foreign company. Since for purposes of $\S 15$ (d) the offering price is based on the aggregate charges to be received by the bank for issuing the ADR's, the undertaking under that section does not generally become operative. Under amended $\S 15$ (d) the Commission could require periodic reports with respect to ADR's registered after Augnst 20,1964, for the fiscal year in which the registration statement becomes effective and for any subsequent fiscal year on the first day of which there are 300 or more record holders.

${ }^{190}$ See discussion of proposed Rule $12 \mathrm{~g} 5-1$ (b) (1) accompanying note 91 supra.

101 See 2 Loss 1095.

${ }^{102}$ Under $\$ 2(4)$ of the Securities Act and $\$ 3(a)(8)$ of the Exchange Act, the foreign issuer is defined as the issuer of the ADR's when it performs the acts and assumes the duties of depositor or manager of the depositary arrangement. See 2 Loss 462.65. 
deemed appropriate-require the issuer of an underlying security to reasonably attempt to transmit proxy material to the record holders of the ADR's whether or not the ADR's are registered. ${ }^{193}$

As the foregoing discussion indicates, the application of sections $12(\mathrm{~g}), 13,14$ and 16 to foreign securities and certificates of deposit for such securities involves a number of important and perplexing problems. The Commission has indicated that it intends to study these problems during the period of the temporary exemption and believes that "it can administer the provisions of the Amendments Act with respect to foreign securities in a manner that will provide the greatest practical benefits for American investors, while at the same time not disrupting existing trading markets or penalizing foreign issuers."194 This goal surely is one of the most challenging tasks presented by the new legislation.

Even more challenging to the Commission may be the problems encountered in the enforcement of the requirements of the Exchange Act against recalcitrant foreign issuers and their insiders. Under section 27 of the Exchange Act, United States district courts have exclusive jurisdiction over violations of, and suits to enforce any liability or duty created by, the act and rules thereunder. And even if service could be obtained on non-resident defendants, it is doubtful than an injunctive order or judgment could be effectively enforced in many instances. ${ }^{195}$

Nevertheless, the difficulties of enforcement should play a decidedly secondary role to measures of the number of United States shareholders and of United States relationships in determining the extent to which foreign securities should be subject to sections 12,13 , 14 and 16. It is purely speculative to estimate the interest of foreign issuers in the United States market for their securities, and to anticipate the effect on them of the stigma attached to violating United States laws or their response to pressures brought to bear by brokerdealers making a market in their securities. These factors could pro-

${ }^{203}$ Form S-12 requires only that the depositary bank undertake to transmit to the Commission and make available at its principal place of business any shareholder communications received from the foreign issuer. It may be appropriate for the Commission to amend Form S-12 to require transmission to ADR holders of such communications with respect to securities required to be registered under $\S 12(\mathrm{~g})$.

104 SEC Securities Exch. Act Release No. 7427, Sept. 15, 1964.

${ }^{206}$ See 3 Loss 1852-61; Cohen \& Throop, supra note 178, at 591-96; Note, Enforcing United States Securities Regulation against Canadians: Conflict of Laws Prob. lems, 66 Harv. L. REv. 1081 (1953). 
duce considerable voluntary compliance. The Commission can be expected to contribute to this result by adopting realistic requirements, enlisting the cooperation of foreign governmental authorities and financial communities, and providing appropriate publicity to violations of the laws as it has done with respect to foreign securities problems in other contexts. ${ }^{196}$

\section{c. Inactively Traded Securities}

To justify the shareholder test as the primary criterion for the extension of the disclosure provisions of the Exchange Act to overthe-counter issuers, the Commission relied upon the high correlation found by the Special Study between the number of shareholders and the extent of trading interest in a security, as measured by the number of record transfers and indications of professional dealer interest. ${ }^{197}$ These same findings indicate, however, that section $12(\mathrm{~g})$ will apply to some corporate securities which are not actively traded, ${ }^{198}$ and the Special Study findings do not purport to relate to securities of non-corporate issuers which are not traded in the ordinary channels of the securities markets.

\footnotetext{
${ }^{100}$ To deal with the problem of unregistered distributions of Canadian securitics in the United States, the Commission publishes a "Canadian Restricted List," which is designed to put broker-dealers and investors on notice that the Commission has reason to believe that the issuers named therein are engaged in violations of the registration provisions of $\$ 5$ of the Securities Act. See 1 Loss 706-08; Cohen \&: Throop, stupra note 178, at 595-96; Kukatush Mining Corp. v. SEC, 309 F.2d 647 (D.C. Cir. 1962). Unlike the problem met by the Canadian Restricted List, violations of $\S 12(\mathrm{~g})$ do not affect the legality of trading. However, under the antifraud provisions the Commission could require appropriate disclosures in connection with transactions in securities which have not been registered as required by $\S 12(\mathrm{~g})$. House Report 11 . On one occasion, when it appeared that widespread interest was being gencrated in the shares of Volkswagenwerk A. G., the Commission publicly warned broker-dealers of their duty to inform prospective purchasers of the lnck of such information concerning the issucr as would customarily be available. SEC Securities Act Relcase No. 4352, April 12, 1961. The Commission's $\$ 15$ (c) (5) powers could be utilized to reach fraudulent selling campaigns in unregistered securitics, whether of domestic or forcign issuers. See 110 Cong. Rec. 17332 (daily ed. Aug. 4, 1964). See also House Hearings, pt. 1, at 179. A provision in the Commission's April 19, 1963, draft which was deleted before introduction, provided for the exercise of Commission exemptive power if it found that $\S 12(\mathrm{~g})$ "may not be susceptible of enforcement against foreign issucs and issuers." Id. at 659 . 20-26.

${ }^{107}$ Senate Hearings 395; House Hearings, pt. 1, at 169. See Special Study, pt. 3, at

${ }^{108}$ The Special Study's findings indicate that in 1961, approximately $23 \%$ of the issuers surveyed that met the coverage criteria of $\S 12$ (g) had less than 200 record transfers and that fewer than two broker-dealers had expressed an interest in the securities of $26 \%$ of these issuers. SENATE REPORT 20; Senate Hearings 395; House Hearings, pt. 1, at 169.
} 
It is likely, therefore, that the coverage criteria of section $12(\mathrm{~g})$ will extend to large numbers of inactively traded securities. This will include securities of issuers organized in normal corporate form as well as interests in real estate syndications, investment trusts, oil and gas wells, employee pension and profit sharing plans and a variety of promotional enterprises. Although the exemptive authority of section $12(\mathrm{~h})$ is designed to permit the Commission to grant blanket or partial exemptions from sections 12 (g), 13, 14 and 16 for these securities, there is very little indication in the legislative history as to the use the Commission intends to make of this authority in this respect.

Section $12(\mathrm{~h})$ does refer to the amount of trading interest as a criteria for exercising exemptive authority, but this reference would seem to have little effect on the broad discretion permitted the Commission. There would seem to be little justification for providing a blanket exemption from sections $12,13,14$ and 16 for the securities of corporate issuers solely on the basis of lack of trading activity. And only to the extent that it can be demonstrated that the willingness of insiders to trade is essential for liquidity in these securities would a limited exemption from section $16(\mathrm{~b})$-but not from sections 16 (a) and 16 (c)-be appropriate. ${ }^{199}$ Moreover, some modifications of, or exemptions from, section 14 might be appropriate with respect to classes of securities in which the public investor interest is represented mainly by voting trust certificates, certificates of deposit and interests in employee pension or stock purchase plans. ${ }^{200}$

${ }^{100}$ The Senate Committee stated that the extent of trading interest in the securities of issuers meeting the coverage criteria of $\S 12(\mathrm{~g})$ suggested that the market for these securities is not dependent on the willingness of insiders to trade. SENATE REPORT 22. While market liquidity for securities which attract less than average trading interest could possibly be more dependent on insider trading, this has not been factually demonstrated.

${ }^{200}$ Proposed Rule 12g5-1 (b) would provide that, with respect to securities held by voting trusts, depositary arrangements and employee plans, the record holders of voting trust certificates and certificates of deposit and persons with a direct beneficial interest in employee plans would be deemed the record holders of the underlying security. However, only the underlying security would be registered unless the class of certificates or plan interests satisfied the coverage criteria separately. Thus, $\S 14$ would apply only to solicitations with respect to the underlying security. Section 16 , however, may apply to transactions in unregistered certificates for a registered security, since beneficial ownership of the certificate is considered beneficial ownership of the underlying security. See 2 Loss 1095. Registration of a class of voting trust certificates meeting the coverage criteria of $\S 12(\mathrm{~g})$ would serve three additional purposes: (1) wider disclosure of matters pertaining to the voting trust; (2) application of the proxy rules to 
Other considerations arise with respect to interests in real estate syndications, investment trusts and oil and gas operations. To the extent that these securities have not been offered pursuant to an effective Securities Act registration statement, the application of sections 12 and 13 can elicit material disclosures for public investors. Moreover, while there may be few occasions for solicitations of proxies in connection with real estate syndications, in which public investors usually hold limited partnership interests, and in connection with oil and gas operations, the definition of solicitation contained in the proxy rules may be broad enough to provide protections in some situations. ${ }^{201}$ Exemptions from section 16 might be considered on the basis of liquidity provided by insider transactions.

Presumably, section 12 (g) will also apply to stock-like interests in a wide variety of promotional enterprises which meet the broad definition of the terms "security" and "equity security" contained in sections $3(\mathrm{a})(10)$ and $3(\mathrm{a})(11)$ of the Exchange Act. Section 3 (a) (10) includes as "securities" participations in profit sharing agreements and investment contracts. In SEC v.W. J. Howey Co., ${ }^{202}$ the Supreme Court held that the term "investment contract" for purposes of the Securities Act means "a contract, transaction or scheme whereby a person invests his money in a common enterprise and is led to expect profits solely from the efforts of the promoter or a third party, it being immaterial whether the shares in the enterprise are evidenced by formal certificates or by nominal interests in the physical assets employed in the enterprise."203 The Court there found that a public offering of orange grove acreage, coupled with service contracts for cultivation of the land and harvesting and marketing of the crop, was subject to the registration requirements of the Securities Act.

Consistent with this broad concept of a security, the courts also have held that registration under the Securities Act is required for public offerings of deeds of trust and other real property interests

solicitations of consents or authorizations from the certificate lolders for such purposes as changing the terms of the voting trust; and (3) application of $\$ 16$ to transactions of the voting trustees, committee members or other persons who perform the functions of officers or directors with respect to the trust. Ibid.

${ }^{201}$ Under the definition of proxy in Rule 14a-1, a consent or authorization may take the form of a failure to object or dissent.

202328 U.S. 293 (1946).

${ }^{208} I d$. at 298-99. 
when coupled with management services, ${ }^{204}$ interests in investment pools, ${ }^{205}$ animals, ${ }^{200}$ vending machines, ${ }^{207}$ and coin portfolios ${ }^{208}$ when management services are also being offered, and interests in oil wells, even though drilling operations will be conducted by third parties. ${ }^{209}$ These interests are not "equity securities" in the conventional sense, but they do carry the essential characteristics of equity intereststhe right to share in the profits of the enterprise and the obligation to suffer the losses incurred. ${ }^{210}$ In some instances, the interest of an investor is limited to specific property and does not consist of an undivided interest in the common enterprise. It might be argued, however, that since the profitability of the investment is often more closely related to factors common to the enterprise-management services and market conditions-than to the condition of the specific property, all of these investments constitute a single class of equity security for purposes of section $12(\mathrm{~g})$.

Even assuming that section 12 (g) applies to these securities, there remains the question whether registration will serve any meaningful purpose. These securities are commonly sold by means of a continuing promotional effort, and unless they fall within a specified exemption the issuers are subject to the registration requirements of the Securities Act and the periodic reporting requirements under section 15 (d) of the Exchange Act. In these situations the registration and reporting requirements of sections 12 (g) and 13 would be superfluous. Moreover, since many of these securities are redeemable by their issuers and there is generally little, if any, trading in others of these securities, they may not present the opportunities for insider speculation which section 16 was designed to deter. Furthermore, since the structures of these enterprises do not nor-

\footnotetext{
${ }^{20}$ Los Angeles Trust Deed \& Mortgage Exch. v. SEC, 264 F.2d 199, 211-12 (9th Cir. 1959).

${ }^{205}$ SEC v. Wickham, 12 F. Supp. 245 (D. Minn. 1935).

${ }^{200}$ SEG v. Chinchilla, Inc., CCH FED. SEC. L. REP. I 90618 (N.D. Ill. March 16, 1953).

${ }^{207}$ Ascher v. United States, 143 F.2d 592 (6th Cir. 1944).

${ }^{200}$ SEC v. Comstock Coin Co., CCH FED. SEC. L. Rep. If 91414 (D. Nev. June 16, 1964).

${ }^{200}$ SEC v. C. M. Joiner Leasing Corp., 320 U.S. 344 (1943); Roe v. United States, 287 F.2d 435 (5th Gir. 1961).

${ }^{210}$ Membership in various types of plans or clubs has been held to involve the issuance of a security. 1 Loss 495-96. Indeed, even membership in the New York Stock Exchange, an unincorporated association and a leading proponent of the Amendments Act, might be considered an equity security required to be registered under $\S 12$ (g). Of course, such a result probably was not intended.
} 
mally provide for meetings of security holders or for shareholder votes, there would be little occasion for application of the proxy rules except in the relatively rare situation when the consent or authorization of security holders is solicited. ${ }^{211}$

Somewhat similar considerations apply to the application of section $12(\mathrm{~g})$ to employee pension, stock purchase and similar plans. The Commission has generally taken the position that any plan which provides for the investment of employee funds with the expectation of a return involves a security. However, registration under the Securities Act has been required only for securities of a plan under which the employee has an option to contribute his own funds and the plan invests employee contributions in the securities of the employer or its affiliates. Registration is not required for compulsory, contributory or non-contributory plans (on the theory that no sale of a security to the employee is involved) or for optional contributory plans which do not invest employee contributions in the employer's securities. This latter position is supported more by broad policy considerations than by the literal terms of the statute.212 Registration under the Securities Act also is not required for interests in collective investment funds sponsored by insurance companies or banks and operated solely as investment mediums for funds of employee

${ }^{211}$ But see note 201 supra.

${ }^{212}$ See CCH Fed. Sec. L. Rep. I 75,195; 1 CCH Fed. Sec. L. Rer. If 2105.52. In 1934 the Senate added a provision to the bill which later became the İxchange Act that would have amended $\S 4(1)$ of the Securities Act to provide that an offering of an interest in an employee extra-compensation or stock-investment plan should not be deemed a "public offering" of securities. This provision was deleted by the Conference Committee "on the ground that the participants in employees' stock-investment plans may be in as great need of the protection afforded by availability of information concerning the issuer for which they work as are most other members of the public." H.R. ReP. No. 1838, 73d Cong., 2d Sess. 41 (1934). See also 78 Conc. REc. 10181-82 (1934); SEC v. Ralston Purina Co., 346 U.S. 119, 126 n.13 (1953). However, with respect to compulsory contributory plans there is no clement of volition on the part of the employee and thus no investment decision for which information is needed. There is, of course, an clement of volition when contributions to the plan are optional. However, if registration were required the burden of compliance might be borne by the employers, which have no direct financial interest in the plan, and they might be discouraged from offering such plans. On tne other hand, it might be argued that employers offer these plans because, like other fringe benefits, they assist in employee recruiting efforts and in maintaining employee morale, and therefore the costs of registration would not be a deterrent. However, employee plans are only one aspect of the complex of fringe benefits in management-labor relations, and the Commission has preferred to leave any necded regulation in this area for others. For an excellent discussion, see Mundheim \& Henderson, Applicability of the Federal Securities Laws to Pension and Profit-Sharing Plans, 29 Law \& Contemp. Prob. 795 (1964). See also 1 Loss 506.11. 
plans where such interests are not "publicly" offered. ${ }^{213}$ The Investment Company Act and the rule thereunder contain certain exemptions from registration under that act for employee plans qualifying under the Internal Revenue Code and collective investment funds operated for such plans. ${ }^{214}$

It seems clear that interests in most employee pension, stock purchase and similar plans-contributory or non-contributoryand in commingled funds operated for such plans are "equity securities" for purposes of section $12(\mathrm{~g})$. Here again, except for a limited application of the proxy rules when consents or authorizations are being solicited, registration under section 12 (g) would often serve no useful purpose. There is no trading in these securities, and where there is a need for disclosure the registration requirements of the Securities Act and section I5 (d) of the Exchange Act can usually serve the same function as sections 12 and 13 would serve. It may therefore be appropriate for the Commission to grant broad exemptions from sections $12,13,14$ and 16 for interests in employee pension, stock purchase and similar plans. ${ }^{215}$

\footnotetext{
${ }^{213}$ See SEC Securities Act Rule 156, I7 C.F.R. § 230.156 (1964), which defines as not involving a "public offering," transactions with respect to a separate account group annuity contract with an employer or employers, provided the contract meets the conditions and limitations for exemption under the Investment Company Act pursuant to Rule $3 c-3$, is separately negotiated, and is not advertised except in specified respects. The Commission has taken the same position administratively with respect to common trust funds operated by banks solely as investment mediums for employee pension plans. See Mundheim \& Henderson, supra note 212, at 819-41. The Commission has not extended this position to variable annuities and interests in bank common trust funds offered as pension plans to qualify for tax benefits provided by the Self Employed Individuals Tax Retirement Act of 1962, 76 Stat. 809 (1962) (codified in scattered sections of 26 U.S.C.) (commonly referred to as H.R. 10). The Commission's assertion of jurisdiction over such plans under the Securities Act, and over bank common trust funds operated as investment mediums for managing agency accounts under both the Securities and Investment Company Acts, has involved it in conflict with the Comptroller of the Currency and has created much discussion. See Mundheim \& Henderson, supra note 212; Comment, The Expanding Jurisdiction of the Securities and Exchange Commission: Variable Annuities and Bank Collective Investment Funds, 62 Mrch. L. REv. 1398 (1964); Comment, Regulation of Bank-Operated Collective Investment Funds-Judicial or Legislative Resolution of an Administrative Controversy?, 73 YALE L.J. 1249 (1964). See also H.R. Rer. No. 429, 88th Cong., 1st Sess. (1963).

a14 Investment Company Act of $1940 \S 3$ (c) (13), 54 Stat. 798 (1940), 15 U.S.C. $\S 80 \mathrm{a}-3$ (c) (13) (1958); SLC Investment Co. Act Rule 3c-3, 17 C.F.R. $\$ 270.3 \mathrm{c}-3$ (1964), as amended, SEC Inv. Co. Act Release No. 4007, July 2, 1964. See also Mundheim \& Henderson, supra note 212, at 814-16, 834-37.

${ }^{215}$ In light of $\S 12(\mathrm{i})$ and the $\S 12(\mathrm{~g})(2)(\mathrm{G})$ exemption, the determination of who is the "issuer" will be important. For a discussion of the "issuer" questions in this area, see Mundheim \& Henderson, supra note 212, at 829-30.
} 
Termination of Registration

Section 12 (g) (4) provides for termination of registration for a class of securities registered under section $12(\mathrm{~g})$ when the record ownership of that class is reduced to fewer than 300 holders. Registration would terminate ninety days after the issuer files a certification to that effect or within such shorter time as the Commission may direct. The Commission may deny deregistration if, after notice and opportunity for hearing, it finds that the certification is untrue. Deregistration is deferred pending a final determination on the question of denial. Presumably, the power to deny would be lost unless proceedings were instituted within ninety days after the certification is filed. ${ }^{216}$

Unlike the tests for registration under section 12 (g) (1) and for suspension of reporting obligations under section 15 (d), the number of record holders may, for purposes of deregistration, be measured on any day of the issuer's fiscal year. Section $12(\mathrm{~g})(4)$ is phrased in the present tense-deregistration occurs ninety days after the issuer files a certification with the Commission that the number of shareholders is reduced to less than 300 persons. Thus, the record ownership must be less than 300 persons on the date the certification is filed, but it appears that subsequent changes in record ownership will not affect the issuer's right to deregistration. For example, an issuer with 290 holders on June 1 , and 310 holders on June 10, apparently could not deregister if it filed its certification on the latter date, but could if it filed on the earlier date. Of course, the issuer would be required to register any class of security which has become deregistered if, on the last day of its fiscal year in which the certification is filed or of any subsequent fiscal year, the class of security meets the registration criteria of section 12 (g) (1).

Upon deregistration of a class of security, the periodic reporting, proxy and insider trading provisions of sections 13, 14 and 16 cease to be applicable to that security, although section 15 (d) may become

${ }^{216}$ If, in fact, the issuer has 300 or more record holders on the certification datc, it might be argued that $\S \S 12,13,14$ and 16 are still applicable because the securities are required to be registered. Indeed, where an issuer with 300 or more holders files a certification not accurately disclosing all pertinent facts and the Commission does not institute proceedings within ninety days, the courts might apply the "required to be registered" doctrine even if it were not applied to issuers never having filed a $\$ 12$ (g) registration statement. In such a situation the courts might even take the tack that failure to disclose all pertinent facts simply vitiates the deregistration. 
applicable. ${ }^{217}$ The legislative history makes it clear that the Commission could require information, documents and reports pertaining to events occurring prior to deregistration even though they are not required to be filed under Commission rules until after registration is terminated. ${ }^{218}$ There is no indication how this rule will be applied with respect to annual or semi-annual reports covering a period which includes the date on which registration is terminated.

The legislative history does not state whether an issuer can terminate registration if it becomes eligible for an exemption from section 12 (g) subsequent to registration. Such a result would seem to be indicated by the underlying policies of the statutory exemptions contained in section 12 (g) (2). Literally, however, the exemptions only excuse registration and do not provide grounds for deregistration; a reduction in holders of record to fewer than 300 is the only grounds for deregistration. Nevertheless, section 12 (g) (2) provides that the "provisions of [section $12(\mathrm{~g})]$. . . shall not apply in respect of" the securities which are exempted. Thus, if an exemption becomes available, the security may automatically cease to be registered under section $12(\mathrm{~g})$ and cease to be covered by sections 13,14 and 16 . The Commission has adequate authority to resolve this question pursuant to section $12(\mathrm{~h})$. The Commission could also provide under section 12 (h) partial or complete exemptions from sections 13,14 and 16 for issuers whose assets are reduced to one million dollars or less subsequent to registration. ${ }^{219}$

\section{The Marketmaker Exemption}

New section 16 (d) provides a limited exemption from sections $16(\mathrm{~b})$ and 16 (c) for certain marketmaking transactions of insidermarketmakers. In the main, the exemption merely limits the extension of sections 16 (b) and 16 (c) made by the Amendments Act and does not restrict the pre-existing scope of those sections. ${ }^{220}$

\footnotetext{
${ }^{217}$ The duty to file reports under amended $\S 15$ (d) is suspended only as long as a security is registered pursuant to $\$ 12$. Section 15 (d) would become applicable upon deregistration if the issuer has offered any class of securities pursuant to an effective Securities Act registration and the tests of amended $\S 15$ (d) are met.

"18 Senate REPORT 62; House Hearings, pt. 1, at 215.

${ }^{310}$ Section 12 (h) specifically refers to assets as a basis for the exercise of the Commission's exemptive authority.

${ }^{330}$ This exemption was one of the most controversial portions of the Commission's legislative program. The Special Study had recommended that there be no general exemption, but that the Commission be empowered to grant ad hoc exemptions where an insider-marketmaker persuaded the Commission that there was a "unique" need
} 
The exemption must be viewed in two stages. The first sentence of section 16 (d) states that:

The provisions of subsection (b) of this section shall not apply to any purchase and sale, or sale and purchase, and the provisions of subsection (c) of this section shall not apply to any sale, of an equity security not then or theretofore held by him in an investment account, by a dealer in the ordinary course of his business and incident to the establishment or maintenance by him of a primary or secondary market (otherwise than on a national securities exchange or an exchange exempted from registration under section 5 of this title) for such security.

The second sentence, however, makes it clear that the scope of the exemption will be subject to broad Commission discretion, for it empowers the Commission, "as it deems necessary or appropriate in the public interest," to define all key terms and prescribe terms and conditions limiting the exemption. Thus, although section 16 (d) is self-executing and became effective on August 20, 1964, the Commission has far-reaching powers to mold it. In addition, the Commission seemingly feels that it would have discretion (presumably under sections $12(\mathrm{~h}), 3(\mathrm{a})(12), 23(\mathrm{a})$, and $16(\mathrm{~b}))$ to exempt from sections 16 (b) and 16 (c) marketmaking transactions that would clearly be

for an exemption. Special Study, pt. 3, at 63-64. The Special Study had reached this conclusion after intense study of the problem. Id. at 42-55. The Commission first agreed with the Special Study, see House Hearings, pt. 1, at 31, and its April 19, 1963, draft contained no marketmaker exemption, although the general exemptive authority provided in that draft was broad enough to grant the type of ad hoc exemptions contemplated by the Special Study. Id. at 659. After the discussions with representatives of the securities industry, the Commission agreed to a compromise suggested by them: There would be a general marketmaker exemption, subjcct to the Commission's power to define the key terms and to prescribe terms and conditions limiting the exemption. Id. at 653-54.

There was no opposition to the exemption in the Senate, although the Senate Committee, at the Commission's suggestion, made several changes in tlie provision. See SeNate RePort 56; Senate Hearings 280. In the House, however, Rep. Dingell, a member of the House Subcommittee, severely criticized the excmption. House Hearings, pt. 2, at 1220-29, 1237-38. The Subcommittee, in its meeting during the third week of March, tentatively deleted it. N.Y. Times, March 21, 1964, p. 29, col. 6. One wcek later the Subcommittee met to make final decisions, and the exemption was rein. stated by a four to three vote. Wall Street Journal, March 26, 1964, p. 2, col. 3. The full House Committee upheld the Subcommittee's final action by an eighteen to thirteen vote, Wall Street Journal, May 8, 1964, p. 3, col. 1, but three members of the House Committee filed a dissent. House RePort 83. Controversy flared again on the House fioor when Rep. Farbstein attacked the provision during the first day of dehate. 110 Conc. REc. 17324-32 (daily ed. Aug. 4, 1964). The flare-up occasioned an overnight letter from the Commission to Chairman Harris, who inserted it in the Congressional Record on Wednesday, August 5, the second and final day of House debate. 110 Conc. REc. I7596-97 (daily ed. Aug. 5, 1964). 
outside the most liberal rule that could be adopted under section 16 (d). ${ }^{221}$

The legislative history establishes that a dealer which is also a broker can qualify for the exemption, ${ }^{222}$ and that the exemption runs to dealers subject to section 30 (f) of the Investment Company Act, which incorporates section 16 of the Exchange Act insofar as securities of closed-end investment companies are concerned.223 In this last respect section $16(\mathrm{~d})$ represents a restriction of the prior scope of sections $16(\mathrm{~b})$ and $16(\mathrm{c}) .^{224}$

Since section 16 (d) does not exempt insider-marketmakers from the reporting requirements of section 16 (a), they will be required to report all transactions, including marketmaking transactions.225 In ascertaining whether the ten per cent ownership test of section 16 (a) is met, all securities, including those in the trading account, are to be counted.226 Furthermore, the exemption does not limit the antifraud provisions of the Exchange Act or other provisions of law. ${ }^{227}$ This means that the Cady, Roberts ${ }^{228}$ doctrine will remain a problem for insider-marketmakers; and if the Commission and the courts were to adopt a broad imputation of knowledge doctrine, the combination might become especially difficult. ${ }^{229}$

Although the point was never squarely dealt with in the legislative history, the exemption appears to cover both: (1) a firm which under Blau v. Lehman ${ }^{230}$ would, but for the exemption, be subject to recovery of all of its trading profits, and (2) a principal of a firm where only his pro rata part of the firm's trading profits would, under Blau and absent section 16 (d), be subject to recapture.

The Committee reports and the Commission's statements provide some guidance as to the meaning of the key terms used in the sec-

\footnotetext{
221 See House Hearings, pt. 1, at 328-31.

222 SENATE REPORT 56; House Hearings, pt. 1, at 221.

223 SENATE REPORT 23, 70; House Hearings, pt. I, at 181, 222.

224 The Commission's statements on this point in its letter reprinted in the Congressional Record are slightly oversimplified. See 110 CoNG. REc. 17597 (daily ed. Aug. 5, 1964).

${ }_{225}$ See Senate Report 23; House Hearings, pt. 1, at 181; 110 Cong. Rec. 17597-98 (daily ed. Aug. 5, 1964).

220 SENATE REPORT 70; House Hearings, pt. 1, at 222.

${ }^{227}$ House Hearings, pt. 2, at 1220-29; Senate Hearings 401; 110 CoNG. REc. 17332 (daily ed. Aug. 4, 1964) (remarks of Rep. Keith); 110 CoNG. REc. 17597-99 (daily ed. Aug. 5, 1964).

${ }^{298}$ Cady, Roberts \& Co., 40 S.E.C. 907 (1961).

220 See Special Study, pt. 1, at 428-40.

238 368 U.S. 403 (1962).
} 
tion. In light of the generality of the legislative history, it does not rigidly restrict the sweeping definitional and rulemaking power given the Commission; but the legislative history is the sole guide for transactions between August 20, 1964, and the adoption of the Commission's rules, assuming the rules are not made retroactive. Moreover, the Commission's statements and the committee reports, though general, provide clues regarding the definitions and rules which Congress and the Commission had in mind. The following discussion of some of the questions arising under the section takes note of the pertinent language in the committee reports and the Commission's statements. Of course, the federal banking regulatory agencies have authority under section 12 (i) to set the scope of the exemption with respect to the securities of banks under their respective jurisdictions.

The first question arising under section 16 (d) is what is a primary or secondary market? The Senate Report states that:

The exemption is limited to transactions by dealers in securities for which they are making an over-the-counter market. Thus, at the time of the transaction, the dealer must have been indicating his willingness to other brokers and dealers to buy and sell such securities on a regular basis for his own account at realistic prices. A dealer generally considered by other brokers or dealers having orders to buy or sell a security as the principal source or market for the execution of such orders is regarded as making the primary or principal market. Secondary markets are made by dealers who trade in a security regularly but on a more limited basis. A transaction by a dealer would not be exempt if incident to a market established or maintained by another dealer. If more than one dealer is making a market in a security at the same time, the marketmaking transactions of all such dealers would be exempt. ${ }^{231}$

The Commission's statements to the House Subcommittee largely repeat that language. ${ }^{232}$ The requirement that a dealer be willing to both buy and sell, and the requirement that such purchases and sales be incident to the establishment or maintenance of a market raise a serious question whether the exemption is available when a marketmaker ceases that function, ceases buying the security, stops entering two-way quotations, and liquidates his inventory. Can his liquidations be exempt?

\footnotetext{
231 Senate Report 70.

${ }^{282}$ House Hearings, pt. 1, at 221. Should any significance be attached to the fact that the Commission's statement to the House Subcommittee talks of a willingness "to trade" rather than "to buy and sell"?
} 
Second, when is a transaction "incident to" the establishment or maintenance of a market? During the House hearings the Commission stated that:

The 'incident to' requirement means that the transaction must be a part of the dealer's activities in his establishing or maintaining a primary or secondary over-the-counter market. Thus, for example, in the case of a dealer making such a market for a security, sales to and purchases from other broker-dealers of that security would be 'incident to' his establishment or maintenance of the market. ${ }^{233}$

Do transactions with retail customers qualify?

Third, what requirements do the "ordinary course of his business" language impose? The Commission's statement to the House Subcommittee indicated that:

The 'ordinary course of his business' requirement in the main supplies re-emphasis to several points implicit in the other parts of the section. It requires that there be some continuity and regularity in transactions; 'one-shot' or sporadic transactions or series of transactions will not qualify. It also means that one facet of the dealer's business must be marketmaking in the security for which the exemption is claimed..$^{234}$

There is no indication as to how much continuity or regularity is required, or whether big block distributions or purchases by marketmakers will qualify as being "in the ordinary course of [the dealer's] ... business."

The Commission has said that in defining "investment account," it intends to "lean heavily" upon the analogies in the federal income tax laws, which provide a natural starting point. ${ }^{235}$ The nonavailability of the exemption for "investment account" stock seemingly should apply only to specific shares of stock that have been held in an investment account. For example, an insider-marketmaker making a market in X company stock should, with proper earmarking, be able to obtain the exemption for marketmaking transactions in the stock while holding other shares of the stock in an investment account, although transactions in the latter shares could never qualify.

The exemption would seem to be available for transactions in the third market-the over-the-counter market for listed securities -unless the Commission uses its powers to deny the exemption to such transactions. ${ }^{236}$ Though section 16 (d) itself denies the exemp-

\footnotetext{
23s Ibid.

234 Ibid.

${ }^{235} I d$. at 222.

${ }^{230}$ The Commission's statements speak of making an over-the-counter market. This
} 
tion to transactions incident to the establishment or maintenance of a market on any exchange, it does not deny the exemption where the security is traded on an exchange or has its primary market thereon. Neither does the section deny the exemption to exchange transactions incident to the establishment or maintenance of a nonexchange market. ${ }^{237}$ To the extent that the Commission's rules allow an exemption for an insider-marketmaker in the third market, this will constitute a second area in which the section will narrow the reach of sections $16(\mathrm{~b})$ and $16(\mathrm{c})$ under prior law.

The exemption is not limited to sponsorship, a special form of marketmaking. Sponsorship is often thought of as a situation where a dealer, after being the managing or principal underwriter of a distribution of the issuer's stock, undertakes to make a continuous market in the stock. ${ }^{238}$ Some of the Commission's materials indicate that the section was intended to deal primarily with the sponsorship problem. ${ }^{239}$ However, most of the legislative history indicates that the section itself does not have such a narrow scope, and that it applies to all primary or secondary marketmakers. ${ }^{240}$

The key statements in the Senate Report, the Commission's statements, and the "ordinary course of his business" language indicate that the exemption may be available only to marketmakers who assume some obligation affirmatively to provide continuity and liquidity. ${ }^{241}$ Much of the material in the House debates attempts to justify the exemption by reference to the liquidity and other benefits that a marketmaker can produce. ${ }^{242}$ Moreover, the testimony of a National Association of Securities Dealers, Inc. (NASD) representative before the Senate Subcommittee indicated that a marketmaker has a "comparability of function" to a specialist. ${ }^{243}$

\footnotetext{
is true even of its suggestion to the Senate Committee of changes in the introduced version of $\S 16$ (d). Senate Hearings 280 . The suggested changes were adopted by the Senate Committce. SENATE REPORT 56.

${ }^{237}$ But see Senate Hearings 359; House Hearings, pt. 1, at 330-31. The authors assume that the parenthetical expression modifies "market."

${ }^{238}$ See Special Study, pt. 3, at 42-55; Senate Hearings 71-73.

${ }^{339}$ House Hearings, pt. 1, at 96, 123.

${ }^{210}$ Thus, whether the dealer has ever been an underwriter of the company's stock would seem immaterial. On the other hand, the section itself, of course, requires some measure of continuous performance.

241 Sec Senate Report 70; House Hearings, pt. 1, at 221.

${ }^{242}$ Sce 110 Conc. REC. $17598-99$ (daily ed. Aug. 5, 1964) (remarks of Rep. Keith).

24s Senate Hearings 71. A few seconds earlier, his phrasing had been that "there is a degree of similarity." Ibid.
} 
In imposing terms and conditions, should the Commission foreclose the exemption to transactions which are in violation of some other section of the Exchange Act, such as section $10(\mathrm{~b})$ ? ${ }^{244}$

Finally it should be noted that under section 30 (b), the provisions of the Exchange Act and rules and regulations thereunder do not apply to any person insofar as he conducts a business in securities outside the jurisdiction of the United States unless he transacts such business in violation of a Commission rule or regulation adopted to prevent evasion. Thus, in the absence of express Commission rules, transactions in securities registered under section 12 executed outside United States jurisdiction by an insider broker-dealer engaged in a securities business in any foreign country are not subject to the pro visions of section 16 if such transctions are incident to his foreign business and do not have a nexus with the United States. ${ }^{245}$

In predicting what the Commission will do in writing rules to deal with these difficult questions, the legislative history on the House side must be kept in mind. The Commission, perhaps out of a concern for the legislation as a whole, fought vigorously to retain the exemption, and in the process, the breadth of its rulemaking powers to limit the exemption and define the key terms, and the liquidity and other benefits that marketmaking can furnish were emphasized by the Commission. ${ }^{246}$ In the House debates congressional supporters of the exemption made much the same points. This could cause the Commission to take a more restrictive attitude than it would have taken if, as was the case in the Senate, there had been no opposition.

Nevertheless, the rulemaking power should not be used to make the exemption meaningless. This all adds up to a tough job for the Commission, which has said that it intends to issue rules in the area. ${ }^{247}$ Undoubtedly, both the securities industry and the courts will want rules which are as definite as possible for their use in interpreting and construing the new provision.

\footnotetext{
34 For a discussion of the question of double liability under $\$ \S 10(\mathrm{~b})$ and $16(\mathrm{~b})$, see 3 Loss 1473-74.

245 See note 391 infra.

240 110 Cong. REc. 17596-97 (daily ed. Aug. 5, 1964) (letter from Chairman Cary to Rep. Harris).

${ }^{247}$ House Hearings, pt. 1, at 221.
} 


\section{Unlisted Trading}

The Amendments Act makes a number of changes in section 12 (f) of the Exchange Act, which governs the trading privileges on a national securities exchange for unlisted and unregistered securities. The principal changes are designed to achieve several purposes: (I) existing trading markets are preserved for securities admitted to unlisted trading on exchanges prior to July 1,$1964 ; 248$ (2) the Commission's authority to extend, suspend and terminate unlisted trading privileges is clarified;240 (3) unnecessary provisions with respect to quotations of transactions in unlisted securities on exchanges are deleted;250 and (4) section $12(f)(3)$, which provided for the extension of unlisted trading privileges to securities of issuers subject to disclosure requirements equivalent to those applicable to issuers of listed securities, is repealed. The only amendment of major significance is the repeal of section 12 (f) (3), which removes a potential threat to the over-the-counter market resulting from the extension of sections $12,13,14$ and 16 to over-the-counter securities.

Prior to the Amendments Act, section 12 (f) limited the extension of unlisted trading privileges to securities which were either: (l) listed and registered for trading on another national securities exchange, or (2) subject to disclosure and other requirements and obli-

zk8 This is the effective date of new $\S 12(\mathrm{~g})(1)$. The provision was intended to eliminate the need for application and approval by the Commission for securities admitted to unlisted trading privileges before July 1, 1964. Since the Amendments Act was not signed until August 20,1964, however, it does not cover securitics admitted to unlisted trading privileges between July 1 and August 20, 1964-an inadvertent gap. This problem was met by Rule $12 \mathrm{f}-7$, which provides that any security admitted to unlisted trading privileges between July 1 and August 20, 1964, shall be excmpt from $\$ 12$ (a) until September 21, 1964; if a new application was filed by that date, it will be exempt until Commission action is taken under amended $\S 12$ (f)(1)(B). SEC Securities Exch. Act Release No. 7397, Aug. 21, 1964.

${ }^{260}$ Prior to the Amendments Act, $\S 12(f)$ contained a number of specific criteria for the exercise of the Commission's authority with respect to unlisted trading privileges. These have been deleted, but the Commission must still find that its action is neces. sary or appropriate in the public interest or for the protection of investors. The Commission has indicated that it will continue to consider the deleted criteria to the extent that they are relevant in a particular case. SENATE REPORT 59; Senate Hearings 353; House Hearings, pt. 1, at 213 . Rule $12 \mathrm{f}-1$ continues to require the filing of information relating to the deleted criteria.

250 Prior to the Amendments Act, $\S 12$ (f) required national securities exchanges to differentiate clearly in their published quotations between transactions in listed and anlisted securities. This provision was deleted as superfluous, since the commission can alter or supplement exchange rules under $\S 19$ (b) to require such differentiation. SENATE RePORT 60; Senate Hearings 353-54; House Hearings, pt. 1, at 214. Former Rule 12E-5, which related to the deleted statutory provision, has been repealed. SEC Securities Exch. Act Release No. 7408, Sept. 1, 1964. 
gations substantially equivalent to those applicable to an issuer of listed securities and its management. These provisions permitted, without the issuer's consent, the extension of unlisted trading privileges upon the Commission's approval of an exchange's application. Historically, however, section $12(f)(3)$ applications have been approved only for companies registered under the Holding Company Act. ${ }^{251}$ This is because the Commission held in 1945 that it could not approve an application for unlisted trading privileges under section $12(f)(3)$ unless the issuer and its management were subject to the same requirements and obligations as are imposed with respect to listed securities by sections $12,13,14$ and 16.252

The Amendments Act could have given section $12(f)(3)$ far broader application, since issuers of over-the-counter securities registered under section 12 (g) would meet the standards enunciated by the Commission for unlisted trading privileges under section $12(f)(3)$. The Commission, however, recommended the repeal of section 12(f) (3) in accordance with the Special Study's conclusion that allocation of trading markets should be determined by the preferences of issuers and the competing forces of the marketplace. ${ }^{253}$ During the House Hearings, repeal of section $12(f)(3)$ was opposed on the ground that investors should not be deprived of an exchange market and its advantages solely because issuers and their managements refuse to assume the obligations required in listing agreements with exchanges (which sometimes go beyond the requirements of the Exchange Act). ${ }^{254}$ However, the availability of unlisted trading privileges under section $12(\mathfrak{f})(3)$ might have affected the decision of some over-the-counter issuers to list securities required to be registered under section 12(g). Moreover, Commission proceedings for approval of section $12(\mathfrak{f})$ (3) applications might have become a continuing battleground in the competition between the exchange and over-the-counter markets. Most important of all, retention of section 12 (f) (3) might have aroused vehement opposition from overthe-counter dealers to the entire portion of the bill extending sections $12,13,14$ and 16 to over-the-counter issuers. Although the Amendments Act will undoubtedly cause a number of over-the-counter

\footnotetext{
251 See 2 Loss 1148 n.69.

${ }^{252}$ New York Curb Exch., 18 S.E.C. 315 (1945). See 2 Loss 1143-48.

${ }^{253}$ See Special Study, pt. 3, at 57, 63; Senate Hearings 311, 403; House Hearings, pt. I, at 184 .

${ }^{25}$ See the testimony of Lawrence H. Taylor, Chairman of the National Stock Exchange. House Hearings, pt. 2, at 823-36.
} 
issuers to list with exchanges, few over-the-counter dealers opposed the legislation, and it was strongly supported by the NASD. ${ }^{255}$

As a result of new section $12(\mathrm{~g})$ and the amendment to section 15 (d), the Commission has proposed amendments to Rule 12f-4, which provides certain exemptions from sections 13,14 and 16 for specified securities enjoying unlisted trading privileges. ${ }^{2 \pi \mathrm{s}}$

\section{B. Commission Enforcement Powers}

The Amendments Act expands the Commission's power to enforce disclosure provisions of the Exchange Act against issuers and their insiders and to proceed against fraud and manipulation in the over-the-counter market. This is accomplished by the addition of sections 15 (c) (4)-(5) and an amendment to section 20 (c). Section 32 (b) remains applicable to issuers failing to make timely filings under section 15 (d). .57

\section{Section 15(c)(4)}

Section 15 (c) (4) empowers the Commission, after notice and opportunity for hearing, to find that any person subject to the provisions of section 12,13 or 15 (d), or any rule or regulation thereunder, has failed to comply with these requirements in any material respect. An order may be issued requiring compliance upon such terms and conditions and within such time as the Commission may specify.

Although the legislative history indicates that section 15 (c) (4) is analogous to section 19 (a) (2), which provides for the delisting of

${ }^{255}$ During the hearings only a few persons associated with the securities industry opposed, in principle, the extension of $\S \S 12,13,14$ and 16 of the Exchange Act to over-the-counter securities. See Senate Hearings 111.26; House Hearings, pt. 2, at 745-56, 802-21. This is in sharp contrast to earlier hearings on such legislation. See 2 Loss 1152-64. The NASD had, at different times, both supported and opposed earlier proposals. $I d$. at 1156,1158 .

${ }_{206}$ SEC Securities Exch. Act Release No. 7428. Sept. 15, 1964. See also 2 Loss 1143.44.

${ }^{257}$ The House Subcommittee rejected the Commission recommendation to delcte $\S 32$ (b), which provides a $\$ 100$ fine per day for failure to file reports required under $\S 15$ (d). The House Committee extended this provision to cover all reports required under amended $\S 15$ (d). House RePort 12, 31. In 1959, the Commission had recom. mended that $\S 32$ (b) be extended to cover all reports, documents and information required to be filed under the Exchange Act. The subsequent change in the Commis. sion's position was based upon two factors: first, fines are often uncollectible because issuers who fail to file reports are frequently insolvent; secondly, even when fines can be collected, the sanction would fall on the issuer and its security holders, not on the members of management who are responsible for the dereliction. House Hearings, pt. 1, at 323-28. Professor Loss reports that only one claim has ever been made under $\S 32$ (b). 2 Loss 819. 
an exchange-traded security, ${ }^{258}$ there are some important differences. A Commission order under section 15 (c) (4) would be purely remedial; it would not prohibit trading as does a delisting order under section 19 (a) (2) with respect to trading on an exchange. The Senate Report explains that it would be inappropriate to deprive investors of a market for their securities solely because of the failure of the issuer and its management to comply with the disclosure requirements of the Exchange Act. ${ }^{259}$ For this reason, and in order to avoid relieving issuers from disclosure obligations applicable to listed securities, the Commission has been reluctant to utilize its delisting power with respect to exchange-traded securities. ${ }^{260}$

Another distinction is that an order under section 15 (c) (4), unlike a delisting order, is not self-executing. The Commission must apply to a United States district court pursuant to section 2l (f) of the Exchange Act to enforce the order. ${ }^{261}$ Under section 25 (a) judicial review of a section 15 (c) (4) order can be obtained in the United States courts of appeal by filing a petition to review within sixty days of the entry of the order. It is not clear what effect section 25 (a) will have upon the scope of review by a United States district court in an action by the Commission to enforce a section 15 (c) (4) order. ${ }^{262}$

\footnotetext{
358 Senate Report 25-26; Senate Hearings 402-03; House Hearings, pt. 1, at 183.

${ }^{250}$ SENATE REPORT 25-26. See S. 1168, 85th Cong., 1st Sess. $\$ 4$ (1957) (reprinted, Senate Hearings 466-68).

${ }^{200}$ Senate Report 26; House Hearings, pt. 1, at 183.

${ }^{901}$ SENATE RePort 66; Senate Hearings 358, 402; House Hearings, pt. 1, at 183, 218. Violation of the order is not a crime under $\$ 32$ (a).

${ }^{205}$ There is considerable authority for the view that $\S 25$ (a) provides the exclusive avenue for judicial review of Commission orders under the Exchange Act. See R. A. Holman \& Co. v. SEG, 299 F.2d 127 (D.C. Cir.), cert. denied, 370 U.S. 911 (1962); Okin v. SEG, 130 F.2d 903 (2d Cir. 1942), affirming 46 F. Supp. 481 (S.D.N.Y. 1942); American Sumatra Tobacco Corp. v. SEC, 93 F.2d 236 (D.C. Cir. 1937); SEC v. Andrews, 88 F.2d 441 (2d Cir. 1937). Each of these cases, however, involved a suit to enjoin Commission action after the relief sought had been denied by the Commission. On the other hand, a $\$ 15$ (c) (4) order may not produce legal consequences unless the Commission chooses to institute an enforcement suit. In the absence of a contrary legislative intent, a defendant in a civil suit to enforce an administrative order may usually defend on the ground that the order is invalid. 3 DAvis, ADministrative Law 320 (1958).

The legislative history of the Exchange Act and the Amendments Act is silent with regard to the scope of judicial review. Section 25 (a) only states that the jurisdiction of the court of appeals is exclusive upon filing of the record. In a Commission action for enforcement of a $\$ 15$ (c) (4) order, this section would not necessarily preclude the defendant from raising any defenses that could have been asserted as a ground for disaffirmance in the courts of appeals. Nor would it necessarily oust a district court of jurisdiction to entertain a Commission action to enforce a $\$ 15$ (c) (4) order if, subsequent to the institution of that action, a timely petition for review of the order is filed in a court of appeals pursuant to $\$ 25$ (a). The choice of forum might, however, rest within the discretion of the court of appeals. Section 25 (a) provides that the
} 
The Senate Report notes that section 15 (c) (4) retains the useful features of delisting proceedings under section 19 (a) (2) by providing an administrative forum for the resolution of accounting and other technical questions arising from the disclosure provisions of the act, and by providing a means of informing investors of materially false and misleading filings concerning their securities. ${ }^{203}$ Since section 15 (c) (4) proceedings are directed against any person subject to the provisions of section 12, they may also be useful in determining questions relating to the valuation of assets and the computation of the number of holders for purposes of sections $12(\mathrm{~g})$ and $15(\mathrm{~d})$.

The Commission could still institute an action under section 21 for a mandatory injunction against violations of section 12, 13 or 15 (d) in lieu of proceedings under section 15 (c) (4). The main advantage of a section 15 (c) (4) proceeding would seem to be that the Commission can better apply its expertise and articulate its accounting and disclosure standards in its own proceedings. ${ }^{204}$

Unlike delisting proceedings under section 19 (a) (2), which can be instituted for a violation of any provision of the Exchange Act, section 15 (c) (4) proceedings can be utilized only to determine material deficiencies in information required to be filed under sections 12,13 and 15 (d). They do not apply to insider reports of security holdings and changes therein required under section 16 (a). This is possibly because complex accounting, technical and factual questions generally are not involved in the administration of that section. Section 15 (c) (4) also does not apply to proxy material filed under section 14. The two-step administrative and court procedure outlined in section 15 (c) (4) is probably too protracted for effective enforcement of the proxy rules. Unlike registration statements and periodic reports filed with the Commission under sections 12 and 13, proxy material is delivered directly to shareholders for immediate

factual findings of the Commission shall be conclusive, if supported by substantial evidence, and that no objection shall be considered by the court unless it has been urged before the Commission. Even if review of a $\$ 15$ (c) (4) order is obtained by way of defenses raised in an enforcement proceeding, the same deference ought to be accorded the Commission's determination as would be given by the court of appeals upon a petition for review under $\S 25$ (a). This would seem to be in keeping with the basic purpose of $\S 15$ (c) (4), that is, to provide an administrative forum for the resolution of complex factual and technical questions.

263 SENATE REPORT 26, 66.

204 For a detailed analysis of the role played by Commission adjudications in a related area, see Cohen \& Rabin, Broker-Dealer Selling Practice Standards: The Importance of Administrative Adjudication in their Development, 29 LAw \& CoNTEMP. PROB. 691 (1964). 
use. Commission injunctive action would seemingly be more effective than a section 15 (c) (4) proceeding to prevent the use of misleading proxy material and to obtain speedy determinations as to the validity of corporate action authorized by proxies allegedly obtained in violation of section 14 . Section 15 (c) (4) proceedings could be used to deal with deficiencies in material which issuers of listed securities are required to file under sections 12 and 13. With respect to listed issuers, the Commission thus has the alternatives of proceeding under either section 15 (c) (4) or 19 (a) (2), or both. For deficiencies in an application for registration or in reports required to be filed under section 13, the Commission could delist a security and then compel compliance for purposes of the over-the-counter trading that may ensue after delisting.

\section{Section 15(c)(5)}

New section 15 (c) (5) empowers the Commission, if in its opinion the public interest and the protection of investors so require, summarily to suspend trading in any security in the over-the-counter market for periods not exceeding ten days. Brokers and dealers are prohibited from using the mails or any facilities of interstate commerce to effect transactions in, or induce the purchase or sale of, any security in which trading has been suspended. Section 15 (c) (5) is designed to operate as a counterpart to the Commission's summary suspension power in section 19 (a) (4) in connection with securities traded on exchanges. As such, it fills a significant gap in the Commission's enforcement powers. ${ }^{265}$

The Commission's power under section 15 (c) (5) is summary; no notice and opportunity for hearing is required. It extends to trading in all securities (except an exempted security as defined in section 3 (a) (12) of the Exchange Act) otherwise than on a national securities exchange. This includes securities which are not registered

\footnotetext{
${ }^{205}$ The Commission has prohibited brokers and dealers from effecting or inducing over-the-counter transactions in any security suspended from trading on an exchange during the period between the public announcement of a suspension to prevent fraud and the expiration or lifting of the suspension. See former Rule 15c2-2, which was repealed, effective September 1, 1964, in light of $\$ 15$ (c) (4). SEC Securities Exch. Act Release No. 7408, Sept. 1, 1964. The Commission has never attempted to utilize its rulemaking authority under $\S 15$ (c) of the Exchange Act to fashion a temporary suspension power over securities traded only in the over-the-counter market; previous legislative recommendations in this respect had never been acted upon. See S. 1179 \& H.R. 2480, 86th Cong., Ist Sess. (1959); S. 1168, 85th Cong., 1st Sess. $\$ 4$ (1957) (reprinted, Senate Hearings 468).
} 
pursuant to section $12(\mathrm{~g})$, and securities traded on exchanges which have been exempted under section 5 from section 6 registration as a national securities exchange. The trading prohibitions apply to all brokers and dealers, whether or not they are registered with the Commission under section $15(\mathrm{~b}) .^{268}$

The legislative history and past Commission practice indicate that the section 15 (c) (5) power will be used mainly in situations where the market has been or will probably be sharply affected by the discovery of serious fraud or manipulation or the disclosure of unexpected, important corporate events. ${ }^{267}$ The Commission also anticipates that section 15 (c) (5) will be helpful in the control of the "hot issue" problem; ${ }^{268}$ this is presumably based upon the Special Study's findings that during the "hot issue" market of the 1950's and early 1960 's, rapidly increasing premiums over the initial offering price of newly-issued securities were frequently induced artificially by the conduct of underwriters and other broker-dealers. ${ }^{260}$ The effect of a suspension order under section 15 (c) (5) would be to freeze the market until adequate information has been disseminated, thereby permitting the resumption of trading on an informed basis.

Section 15 (c) (5), like section 19 (a) (4), limits the duration of a suspension order to "a period not exceeding ten days." Under section 19 (a) (4), however, the Commission had avoided this limitation by issuing a new suspension order every ten days until it found that resumption of trading was appropriate. ${ }^{270}$ The Senate Report recognizes and sanctions this practice, while cautioning the Commission to proceed "with all diligence to develop the necessary facts in order that any suspension can be terminated as soon as possible."271 But investigations into fraud and manipulation are necessarily complex and protracted. They frequently encounter elaborate schemes to conceal and deceive which can be unravelled only by extensive field investigation, interrogation of witnesses, and examination of voluminous records. All this takes time, and despite the expression of

${ }^{200}$ Under new $\S 15(\mathrm{~b})(4)$ brokers and dealers registered under $\S 15(\mathrm{~b})$ would be prohibited from trading in suspended securities even without use of mails or facilitics of interstate commerce. See HOUSE REPORT 24.

${ }^{207}$ Senate REPORT 26; Senate Hearings 403; House Hearings, pt. 1, at 183; 2 Loss 851-55.

${ }^{208}$ SenAte RePORT 26; House Hearings, pt. 1, at 184.

${ }^{260}$ Special Study, pt. 1, at 553-59.

270 See 2 Loss 854-55.

${ }^{271}$ SENATE REPORT 66-67. 
concern, the Senate Report appears to recognize that in the normal case, successive ten-day suspension orders usually will be necessary. ${ }^{272}$

Section 20(c)

Amended section 20 (c) prohibits any officer, director or security holder of any issuer required to file any document, information or report under the Exchange Act or rules or regulations thereunder from hindering, delaying or obstructing such filings. Prior to the Amendments Act, section 20 (c) was limited to officers, directors and security holders of issuers with listed securities or of issuers subject to reporting requirements under section 15 (d). Under amended section 20 (c) the Commission can sue to enjoin interferences with filings required of companies with securities registered under section 12 (g); such matters may also be referred to the Attorney General for criminal prosecution.

\section{Strengthening of Existing Disclosure Requirements}

\section{Section 15(d)}

The reporting requirements of section 15 (d) were extensively revised by the new legislation. Under prior law all issuers filing a Securities Act registration statement, irrespective of whether it related to an equity security, were required to execute an undertaking to file (to the extent required by Commission rules) the same periodic reports that would be required under section 13 of a company with a security listed on a national securities exchange, if the value of the securities registered plus the value (computed at the offering price) of all other outstanding securities of that class amounted to two million dollars or more. Once the undertaking became eftective, periodic reports were to continue unless the value of the securities registered plus all other outstanding securities of the same class fell below one million dollars computed at the offering price. No reporting under section 15 (d) was required so long as the issuer had any security listed and registered on a national securities exchange.

This was the device used to impose reporting requirements, but not proxy or insider trading requirements, on many over-thecounter companies. Under the new legislation, section 12 (g) will ultimately extend the full range of requirements applicable to listed companies to more than 3,500 over-the-counter companies (including

\footnotetext{
27: See also House Hearings, pt. 1 , at 219.
} 
about 1,600 section 15 (b) companies). Congress, however, accepted the Commission's recommendation that section 15 (d) be retained and revised $^{273}$ to reach over-the-counter companies which are too small to be covered under section $12(\mathrm{~g})$, but are large enough to indicate an investor interest warranting the imposition of reporting requirements. It also reaches companies in which there is a large public interest only in purely debt securities, since section 15 (d), unlike section $12(\mathrm{~g})$, does not distinguish between equity and other securities. Therefore, a Securities Act registration statement covering any type of security can give rise to reporting obligations. The section is still keyed to the voluntary filing of a registration statement under the Securities Act, for unless the issuer has filed an effective registration statement under that act, there can be no reporting obligations under section $15(\mathrm{~d})$. That is not the case under section $12(\mathrm{~g})$.

As the first step in the revision, the general exemption from section 15 (d) was expanded to exempt an issuer during any period when it has any security "registered pursuant to section 12." Thus, the general exemption now covers issuers with a security registered under section 12 (g) as well as issuers with a security listed and registered on a national securities exchange. In addition, the general exemption-for no apparent reason-now covers an issuer with a security enjoying unlisted trading privileges on a national securities exchange. This result follows because section $12(f)(6)$ retains the provision that a security enjoying such unlisted trading privileges is deemed to be registered on a national securities exchange for all purposes of the Exchange Act. The Commission, however, has proposed an amendment to Rule 12f-4 which would directly subject an issuer of a security enjoying unlisted trading privileges to section 13 if it would be subject to section 15 (d) but for the unlisted privileges enjoyed by the security. ${ }^{274}$

For those issuers that have filed Securities Act registration statements which have become effective, and which have no security registered under section 12 , the obligation to report is determined

278 The Senate Committee made a number of clarifying changes in the introduced version of the $\$ 15$ (d) amendments. See SENATE REPORT 55-56; Senate Hearings 280.

${ }^{274}$ SEC Securities Exch. Act Release No. 7428, Sept. 15, 1964. One implicit assump. tion underlying the Commission's action is that the "deemed to be registered on a national securities exchange" language of $\$ 12(f)(6)$ necessarily means the security is also deemed to be "registered pursuant to section 12." This secms correct, since a security actually registered on a national securities exchange is registered pursuant to $\$ 12$. 
by one of two formulas, depending upon whether the statement is filed on or before August 20, 1964, or after that date.275

Issuers filing Securities Act registration statements after August 20, 1964, must always file periodic reports for the fiscal year in which the statement becomes effective. In subsequent fiscal years, a yearby-year exemption may be applicable: no periodic reports will be required in any subsequent fiscal year on the first day of which the issuer has fewer than 300 holders of record of each class of securities covered by the Securities Act registration statement. In applying the year-by-year exemption, the number of holders of record is measured only as of the first day of the issuer's fiscal year. ${ }^{276}$ The test is reapplied on the first day of each subsequent fiscal year to determine whether the exemption is available for that year, with the result that the exemption may be available for one year and not the immediately following year, or vice-versa. The year-by-year exemption is never available for the year in which the statement becomes effective. These obligations with respect to Securities Act statements filed after August 20, 1964, are directly imposed by the statute, and the former requirement of executing an undertaking is deleted.

An issuer which has filed a Securities Act registration statement on or before August 20, 1964, is accorded more liberal treatment. Reports under section 15 (d) are required only if the issuer's undertaking filed under prior section 15 (d) so requires, and the year-by-year exemption is not available. For example, so long as the two million dollar test is not met, the issuer is exempt even though it has more than 300 holders of record of the security that was registered. Conversely, even if the undertaking would require reporting, the existence of the year-by-year exemption may excuse the issuer. These more liberal rules apply even to a Securities Act registration statement filed on or before, but becoming effective after, August 20, 1964. .277 The year-by-year exemption is applied in the same manner

\footnotetext{
${ }^{275}$ As establishing that this is the dividing line, see SENATE REPORT 67-69; House Hearings, pt. 1, at 219-20.

270 Thus, a calendar year issuer with 250 holders of record on January 1 and 350 holders of record on July 1 would qualify for the exemption for that entire year. Conversely, if the figures were 350 and 250 on the respective dates, the exemption would not be available for any part of the year. Assets and value of outstanding securities are immaterial for the purpose of applying this test.

${ }^{277}$ SENATE REPORT 67-69; House Hearings, pt. 1, at 219-20. Of course, the lack of effectiveness of an undertaking does not result in the issuer's being exempt from registration under $\$ 12(\mathrm{~g})$; the two are unrelated.
} 
whether the Securities Act registration statement was or is filed before or after August 20, 1964.

The Amendments Act and its legislative history are silent as to the important consideration of whether, for purposes of amended section 15 (d), a Securities Act registration statement is deemed to be "filed" on the first date it is physically filed with the Commission or on the date of the last pre-effective amendment thereto. Under section 8 (a) of the Securities Act, filing is deemed to occur as of the latter date. Seemingly, the former date should control.

The foregoing discussion has dealt with issuers who file only one effective Securities Act registration statement. Where there is more than one such statement, reporting is required, regardless of the date of filing, if the application of these rules to any one or more of the statements would require filing-even though filing would not be required with respect to other statements. ${ }^{278}$ The Senate Report and the Commission's statements emphasize that if the reporting obligation under section 15 (d) is suspended for a period, the suspension does not remove the obligation of the issuer to file with respect to earlier periods when it was covered, even though the reports would be due during the exempt period. ${ }^{275}$ Thus, for example, if the year-by-year exemption is available for 1966 but not 1965, the annual report for 1965 must be filed.280

Although sections $12(\mathrm{~g})$ and 15 (d) both excuse reporting when

${ }^{278}$ Consider a calendar year issuer filing, in 1965, two separate, effective statementsone relating to its common stock and the other relating to its debentures. The issuer will be required to file with respect to 1965 , because the statements become effective during the year. It will be required to file with respect to 1966, if, on January 1, 1966, there are 300 or more holders of record of either the stock or the debentures. Sce SENATE REPORT 68; House Hearings, pt. 1, at 219-20. Or, consider a calendar year issuer which filed an effective statement in 1963 with respect to its common stock and files another registration statement in 1965 with respect to its common stock which becomes effective on July 1, 1965. Assume that the undertaking with respect to the first statement is at no time effective and that the common stock is held of record by 350 persons on January 1, 1964, 280 persons on January 1, 1965, and 310 persons on January 1, 1966. No filings will be required with respect to 1964 , because the undertaking is not effective. Effective July 1, 1965, the issuer will become subject to $\S 15$ (d) because the second statement is effective on that date, and reporting is required with respect to all of 1965. Senate Report 67-68; House Hearings, pt. 1, at 219-20. The fact that no reportiug is required under the first statement becomes immaterial. Reporting will be required under the second statement with respect to 1966, even though the ineffectiveness of the undertaking excuses reporting under the first statement.

${ }^{270}$ SeNATE RePORT 68-69; House Hearings, pt. 1, at 220.

280 Ibid. A similar rule applies when there is deregistration of a security under section $12(\mathrm{~g})$. 
the holders of record fall below 300 , the timing is considerably different. Under section $12(\mathrm{~g})$, deregistration and disengagement from direct reporting obligations can occur at any time during a fiscal year, whereas under section 15 (d) the test is applied as of the first day of the year. ${ }^{281}$ The exemptive authority formerly contained in section 15 (d) was removed because new section $12(\mathrm{~h})$ provides such authority. Section 15 (d) also remains inapplicable to securities of foreign governments.

The Special Study recommended that issuers of future Regulation A issues under the Securities Act be subjected to reporting duties similar to those imposed under section 15 (d) upon issuers using the full registration route under the Securities Act. ${ }^{282}$ This appears to be a logical step that would be consistent with the Amendments Act.

Section 15 (d) retains the former definition of "class," which is to be "construed to include all securities of an issuer which are of substantially similar character and the holders of which enjoy substantially similar rights and privileges." The phrase "held of record," however, is not defined in section 15 (d), and the power to define that term in order "to prevent circumvention of the provisions of" section $12(\mathrm{~g})$ is not applicable to section $15(\mathrm{~d})$. The Commission has, however, proposed a single definition of "held of record" applicable to both sections $12(\mathrm{~g})$ and $15(\mathrm{~d})^{283}$ pursuant to its additional definitional powers in sections 3 (b) and 23 (a). This is consistent with the implication in the legislative history that, in applying the deregistration test under section $12(\mathrm{~g})$ and the test for the

\footnotetext{
${ }^{281}$ Consider a calendar year issuer which makes a public offering of its common stock in 1965 pursuant to a Securities Act registration statement becoming effective in that year. Assume that it registers the stock under $\$ 12(\mathrm{~g})$ in 1966, has 350 holders of record on January 1, 1967, and has 250 holders of record on May 1, 1967. The issuer could deregister the stock under $\S 12(\mathrm{~g})$, effective ninety days after May $1,1967$. Upon deregistration the issuer would be released from direct reporting obligations under $\S 13$, but $\S 15$ (d) would become applicable. While the issuer has its stock registered under $\S 12(\mathrm{~g})$, $\S 15$ (d) would be inapplicable; that exemption, however, would terminate upon deregistration, and the year-by-year exemption would not be available for 1967 because there are more than 300 holders of record on January 1 . Un the other hand, if the January 1,1967 , figure were also 250 , deregistration nnder $\S 12(\mathrm{~g})$ would usually (see $\S 12(\mathrm{~g})(4)$ ) take at least ninety days, and reports would be required under $\S 13$ in respect of that part of 1967 elapsing before deregistration is accomplished. SENATE Rerort 62; House Hearings, pt. 1, at 215. However, the year-byyear exemption under $\$ 15$ (d) would be available for all of the year.

${ }^{282}$ Special Study, pt. 3, at 62-63.

${ }^{283}$ SEC Securities Exch. Act Release No. 7426, Sept. 15, 1964.
} 
year-by-year exemption under section 15 (d), the number of holders of record are to be computed in the same manner. ${ }^{284}$

Because of the removal, with respect to registration statements filed after August 20, 1964, of the requirement that undertakings be filed, conforming amendments were made to sections 20 (c) and 32 (b) to remove the reference to reports required "pursuant to" undertakings under section $15(\mathrm{~d})$. The theory behind the changes was that even with respect to Securities Act registration statements filed on or before August 20,1964, reporting is now directly required under both the statute and the Commission's rules. ${ }^{285}$ Perhaps through inadvertence, the reference to section 15 (d) undertakings remains in several sections. 286

\section{Material Contracts}

The Amendments Act expands section 12 (b) to empower the Commission, in applications for listing, to require the filing of information concerning, and copies of, any type of material contract not made in the ordinary course of business which either was made twithin two years of filing or will be performed, ${ }^{287}$ in whole or in part, after filing. The amendment specifies that every material patent or contract for a material patent right is deemed a material contract. Prior to the Amendments Act, section 12 (b) and the Commission's rules thereunder required information conceruing only limited categories of material contracts, although the Securities Act required the filing of all such contracts in registration statements under that act. The Commission has stated that for purposes of delineating covered material contracts under amended section 12 (b) it will develop guides similar to those in the instructions to its forms for registration statements under the Securities Act. ${ }^{288}$

The amendment also is relevant for purposes of sections $12(\mathrm{~g})$ and 13. Under the former, the registration statement is to require information and documents comparable to that required under sec-

284 SeNATE REPORT 26-27; House Hearings, pt. 1, at 184.

${ }^{285}$ SENATE REPORT 70-71; House Hearings, pt. 1, at 222. The reference in $\$ 15$ (d) to undertakings formerly filed is now essentially an additional exemption.

${ }^{288}$ The reference remains, seemingly as harmless surplusage, in $\$ \S 18(a), 21(f)$, and 32 (a).

- 287 The word in the statute is "executed," which the legislative history interprets as "performed." Senate Report 58; House Report 14. Despite the placement of the commas, "not made in the ordinary course of business" is restrictive. Sec HousE REPORT 14; SENATE REPORT 25; Senate Hearings 352; House Hearings, pt. 1, at 183, 212.

${ }^{282}$ SeNATE REPORT 58; Senate Hearings 352; House Hearings, pt. 1, at 212. 
tion 12 (b). The Amendments Act has broadened section 13 by allowing the Commission to require supplementary information and documents to keep reasonably current the material "required to be included in or filed with an application or registration statement filed pursuant to section 12."289 This change allows the Commission to require a listed or section 12 (g) company, and a section 15 (d) company, to file current information relating to, and copies of, material contracts of the type covered in the amendment to section 12 (b). Thus, filings concerning all such material contracts can be required as they are made and performed. Presently, the Commission's rules and forms under sections 13 and 15 (d) require the current reporting of only limited types of material contracts.

As introduced and as passed by the Senate, the amendment to section 13, when coupled with the amendment to section 12 (b), would seemingly have authorized the Commission to require listed companies to file all material contracts made as early as 1932 , even though they may have been fully performed years ago. The House Committee changed the amendment so that the Commission may not require the filing of any material contract wholly performed before July 1, 1962.290 These amendments to sections $12(\mathrm{~b})$ and 13 will have no effect until implemented by changes in the Commission's rules and forms, as they are only grants of additional rulemaking power.

\section{Changes in Section 14(b)}

Before the Amendments Act, section $14(\mathrm{~b})$ empowered the Commission to prescribe rules and regulations governing the circumstances under which members of a national securities exchange or any broker or dealer conducting business through the medium of such a member could give a proxy, consent, or authorization (a "proxy") in respect of a security registered on a national securities exchange and carried for the account of a customer (in "street name"). The Amendments Act expands section 14 (b) in three respects. The Commission may now prescribe rules governing the circumstances under which any member of a national securities exchange or any broker-dealer registered under section 15(b) (a class

\footnotetext{
${ }^{380}$ Securities Acts Amendments of 1964, $\S 4$, Pub. L. No. 467, 88th Cong., 2d Sess. (Aug. 20, 1964). (Emphasis added.) Formerly, the language had been "to keep reasonably current the information and documents filed pursuant to section 12."

2": See House REPORT 11-12.
} 
more inclusive than firms doing business through the medium of a member) may give or refuse to give a proxy in respect of any street name security which is registered on a national securities exchange ${ }^{201}$ or under section $12(g)$.

This change enables the Commission to adopt rules requiring broker-dealers to transmit proxy solicitation material to beneficial owners of street name securities and to give proxies in accordance with their directions. Former section 14 (b) was interpreted by the Commission as not granting this authority, and, therefore, no rules were promulgated thereunder. ${ }^{202}$ Undoubtedly, this new power extends to the annual reports that Rule $14 \mathrm{a}-3$ (b) requires to accompany or precede solicitation material on behalf of management which relates to an annual meeting at which directors are to be elected. Even though Rule 14a-3 (c) states that the annual report is not "deemed to be soliciting material," it is in fact an integral part of the proxy solicitation materials as evidenced by the fact that its transmission is a condition to the use of other material.

Despite the fact that a recent survey indicates that 7.6 per cent of the shares of all publicly held corporations are registered in the names of broker-dealers, ${ }^{293}$ this change may not have widespread impact, because of the rules of the New York Stock Exchange and the American Stock Exchange. For many years these rules have required their members to forward proxy material with respect to any security to beneficial owners, and to execute and forward the proxy in accordance with their directions. ${ }^{204}$ The rules of the two exchanges condition the obligation upon the solicitor's defraying the mem-

${ }^{201}$ Securities enjoying unlisted trading privileges continue to be covered despite the changes in terminology in $\$ 14$ (b). See text accompanying note 274 supra.

${ }^{202}$ Sce 2 Loss 924-30. Section 14 (b), in its present and previous form, authorizes the Commission to prohibit covered broker-dealers from voting shares without the express consent or instructions of the beneficial owners. See $i d$. at 928 . Though the added language in amended $\S 14$ (b) states only that the rules may prescribe when brokerdealers may "refrain from giving" a proxy, the legislative history establishes that the Commission may adopt rules of the type referred to in the text. Senate Rerorr 65; House Hearings, pt. 1, at 217-18. As a practical matter, the Commission's rulcs under $\$ 14$ (a) force a broker-dealer forwarding the soliciting material of one side in a contest to do so for the other side. Walsh v. Peoria \& Eastern Ry., 222 F. Supp. 516 (S.D.N.Y. 1963). For a discussion of the acts which can make a broker-dealer a solicitor, sce SEC Securities Exch. Act Relcase No. 7208, Jan. 7, 1964.

${ }^{203}$ See note 93 supra.

2942 CCH NEw YORK STOCk Exch. Guide 3805-156; CCH AMERICAN STOCK Excir. Guide 8656-58. Members may, in lieu of requesting instructions, send a signed proxy, with instructions, to be filled in by the beneficial owner and forwarded directly by him to the solicitor. 
ber's reasonable costs. Any Commission rule in this area should contain the same conditions. ${ }^{295}$

Rules under section 14 (b) can relate only to securities registered on a national securities exchange or registered under section 12 (g). In this respect, section 14 (b) does not authorize rules as inclusive as those of the two exchanges. ${ }^{206}$

Section 14 (b) and its legislative history do not settle the question whether the Commission's section 14 (b) rules could require transmission of information statements required under new section 14 (c) when an issuer of a security registered under section 12 does not solicit. ${ }^{207}$ The rules of the New York and American Stock Exchanges seem broad enough to require transmission of those types of statements under the same conditions that soliciting material must be transmitted.208

\section{New Section 14(c)}

Regulation 14, the proxy rules under section $14(\mathrm{a})$, is the most effective disclosure device in the federal securities law

${ }^{205}$ For the condition in the exchanges' rules, see ibid. For the limitation on the Commission's power, see SENATE REPORT 65; House Hearings, pt. 1, at 218.

${ }^{200}$ The Special Study recommended that the National Association of Securities Dealers, Inc. (NASD) adopt a rule similar to those of the exchanges. See Special Study, pt. 3, at 64 . Under new $\S 15(\mathrm{~b})(10)$, the Commission could adopt a similar rule applicable to registered broker-dealers which are not members of that organization, though broker-dealers subject to $\$ 15$ (b) (10) undoubtedly hold few securities in street name. Such a Commission rule would be more inclusive than a $\$ 14$ (b) rule because it would apply to any security. Of course, with a few exceptions, solicitations with respect to securities not registered under $\S 12$ are not subject to the Commission's proxy rules, and soliciting material may not measure up to the Commission's standards. Nevertheless, the implicit judgment of the two exchanges that transmission of such material to beneficial owners is in the public interest is clearly correct.

${ }^{207}$ A literal reading of $\S 14(\mathrm{~b})$ might indicate that the Commission does not possess this power, because the broker-dealer would not be giving or refraining from giving a proxy by refusing to transmit the information statement. The committce reports and the Commission's statements speak of the transmittal of proxy solicitation material, although they do not negate the use of $\S 14(\mathrm{~b})$ for this purpose. The policy behind $\S 14(\mathrm{~b})$ would clearly support use of the section.

2015 2 CCH NEW York STOCK Exch. Guide 3816; CCH AMERICAN STOCK Exch. Guide 8658. The NASD could adopt a rule requiring the transmission of such statements, and the Commission could clearly do so under $\S 15(\mathrm{~b})(10)$ with respect to registered broker-dealers who are not members of the NASD. Any such rule, whether adopted under $\S 14$ (b) or $\S 15$ (b), should be conditioned upon the issuer's defrayal of reasonable expenses, as are the rules of the two exchanges. The exchange rules do not require transmission of either soliciting material or non-soliciting informational material to beneficial owners outside the United States. Is this a proper limitation considering that the solicitor or issuer is paying the expenses? Should not the solicitor or issuer be given the final word? 
arsenal. ${ }^{299}$ The requirement of appropriate disclosures when proxies are solicited sends information straight to the shareholders' mailboxes. Disclosures so transmitted to shareholders are far more meaningful than disclosures under section 13 , which are merely filed with the Commission. For example, it is only through the proxy rules that there is any requirement in the Exchange Act that balance sheets and profit and loss statements be sent to shareholders. Under the Commission's proxy rules those financial statements for the preceding fiscal year must be transmitted when proxies are solicited for any annual meeting at which directors are to be elected.300 Thus, shareholders are periodically supplied with relevant information about the issuer and its activities so long as management solicits proxies.

But section 14 (a) breaks down when management does not solicit proxies, and this happens fairly often. ${ }^{301}$ This problem has been alleviated by the listing agreements and rules of several exchanges requiring solicitation with respect to meetings of holders of listed stocks. ${ }^{302}$ With the enactment of section $12(\mathrm{~g})$, however, there will be many unlisted securities that will be subject to section 14 (a).

New section 14 (c) attacks this problem in a manner different from the approach followed by the exchanges. It requires that any issuer of a security registered on a national securities exchange or registered under section $12(\mathrm{~g})$ must, if proxies are not

solicited by or on behalf of the management of the issuer from the holders of record of such security in accordance with the rules and regulations prescribed under [section 14 (a) ] . . prior to any annual or other meeting of the holders of such security . . . filed with the Commission and transmit to all holders of record of such security information substantially equivalent to the information which would be required to be transmitted if a solicitation were made.

so? 2 Loss 1027.

${ }^{300}$ SEC Securities Exch. Act Rule 14a-3, 17 C.F.R. \$240.14a-3 (1964).

${ }^{301}$ See 29 SEG ANN. REP. 55.

${ }^{30}$ The listing agreements currently in use by both the New York and American Stock Exchanges require solicitation of proxies for all meetings of holders of stock listed on the exchange. New York Stock Exchange-Company Manual p. A-28 (see Listing Agrecment, pt. III, itcm 5); CCH American Stock Exch. Guide 8955 (sec Listing Form L, item 5). Rule 499 of the New York Stock Exchange states that the exchange will normally consider suspending or delisting a security when the issuer does not solicit for all meetings of stockholders. 2 CCH NEw YorK STOCK Excir. Guide $\$ 2499$. See also 2 Loss 1028. 
This must be done "in accordance with rules and regulations prescribed by the Commission," meaning that the section has no impact until implemented by rules and regulations. ${ }^{303}$ The deviation from. the formula used by several exchanges that there must be solicitation of holders gives management more flexibility than if the exchanges'. approach had been followed. But one inevitable result of rules' under section 14 (c) will be that managements will tend to solicit whenever possible.

The wording of the section raises several questions. First, is it applicable if management solicits from some, but not all, holders of: record? The Commission's rules under section 14 (a) allow a partial. solicitation, though there is probably sufficient power in that section" for the Commission to prescribe that if any holders are solicited, all must be solicited..$^{304}$ The wording of section 14 (c) indicates that it is applicable unless all holders of record are solicited. ${ }^{305}$ If the con-1 trary is held to be the case, the answer would be a rule under section. 14 (a) prohibiting any solicitation unless unsolicited holders receive' information statements in accordance with section 14 (c)..$^{306}$

Secondly, suppose there is a partial solicitation not involving a: formal assembly of holders. Does the use of "meeting" in section: 14 (c) indicate that the section is applicable only if a formal assembly. of at least some holders at one place is involved? Again, this is a problem that in any event could probably be solved under section 14 (a).

Thirdly, can rules under section 14 (c) affirmatively require the' transmission of information statements to non-record owners? $A$. concrete example of this question arises in connection with street name securities. Can section 14 (c) rules require the issuer to sup-" ply information statements to broker-dealers for transmission to the beneficial owners and, furthermore, require the issuer to defray' reasonable expenses of the transmission? The answer perhaps lies in the meaning of "holders of record." If that term includes those per-:

${ }^{303}$ SEC Securities Exch. Act Release No. 7425, Sept. 15, 1964.

so' See 2 Loss 1029 n.649.

${ }^{305}$ Section 14 (c) applies unless there has been a solicitation from "the holderis of record ... in accordance with [Regulation 14] ..." This wording indicates that all holders must be solicited, and, of course, the policy of getting information to holders which prompted the amendment would be completely frustrated if a solicitation of, say, $1 \%$ of the holders pursuant to Regulation 14 were deemed to render $\$ 14$ (c) inapplicable. See also note 307 infra.

${ }^{300}$ See note 304 supra and accompanying text. 
sons recorded on the books and records of the broker-dealer as owners of securities, the issuer can be required to "transmit" the information statement to them, and the issuer could undoubtedly be required to defray the reasonable expenses. We have seen earlier in the discussion of sections 12 (g) and 15 (d) the problems surrounding "held of record." For purposes of section $14(\mathrm{c})$, the Commission's definitional powers are limited to sections 3 (b) and 23 (a), which perhaps give it less power than it has under section 12 (g) to define the term for purposes of that section. If the term is defined for section 14 (c) purposes as including only holders shown on the issuer's books, it seems clear that that section does not grant the Commission power to require the issuer to transmit to beneficial owners or defray reasonable costs of brokers-dealers.

Unfortunately, the legislative history does not discuss this question. Opposing arguments may be urged by virtue of the amendment to section 14 (b). On one hand, Congress recognized that beneficial owners of street name securities should be supplied with the same materials that a person who is recorded on the books of the issuer as an owner receives. On the other hand, Congress realized that there is a division of record and actual ownership in street name securities. Yet, in section 14 (c) the holders of record terminology was chosen. Argnably, this indicates an intent that the issuer's obligation was deliberately limited by the choice of terminology.

Where there is solicitation, section 14 (a) may again be relevant; that section might be used to prohibit any solicitation unless those not solicited receive section 14 (c) information statements, and to require that the issuer furnish sufficient statements to broker-dealers holding securities in street name and defray their reasonable transmission costs. "This approach would offer no solution, however, where there is no solicitation of any holders.

Related to this issue is the problem previously discussed in connection with section 14 (b) of whether the Commission's section 14 (b) rules could require broker-dealers, upon defrayal of reasonable costs, to transmit section 14 (c) information statements.

Finally, would violations of section 14 (c) rules lead to implied rights of action similar to those that result from violations of section 14 (a) rules? Although section 14 (c) is primarily a disclosure requirement, the answer would appear to be yes. ${ }^{307}$ For example, the holding

${ }^{307}$ Section $14(c)$ is a legal requirement, and the statements required thereunder 
of a meeting to be conducted without solicitation could seemingly be postponed by injunction until there is compliance with section 14 (c). Moreover, a violation of section 14 (c) could probably, in some cases, be the basis for, say, setting aside the election of directors. ${ }^{308}$

The requirements presently applicable to solicitations for the insertion of shareholders' proposals and mailing of communications for security holders probably should be extended to section 14 (c) information statements. This is done under the proposed regulations of the Federal Reserve Board and the Federal Deposit Insurance Corporation..$^{309}$

One situation which neither section 14 (a) nor 14 (c) appears to enable the Commission to reach is where neither state law nor the trust agreement (or similar instrument) governing the organization and operation of a non-corporate entity requires periodic meetings of the owners. In such cases, solicitations, meetings or required meetings will be rare. ${ }^{310}$

\section{Prospectus-Delivery Requirements under the Securities Act}

The Amendments Act alters that part of prior section 4 (1) of the Securities Act dealing with the prospectus-delivery requirements applicable to dealers who are not members of the selling group following a public offering of securities pursuant to a Securities Act registration statement. If the issuer of the security has not theretofore sold any security pursuant to an earlier effective registration statement, all such dealers must deliver prospectuses for ninety days, rather than forty days, after the institution of a registered public offering. ${ }^{311}$ The pre-existing forty-day requirement remains applicable

are to be distributed before the meeting and to refer to all matters to be voted on at the meeting 4 requiring disclosure in proxy solicitation materials; Congress specifically noted that the statements would have an impact on votes. See SENATE REPORT 25, 66; HOUSE REPORT 19.

${ }^{308}$ See note 307 supra. Cf. J. I. Case Co. v. Borak, 377 U.S. 426 (1964); 2 Loss 960-73.

30029 Fed. Reg. 12120-23 (Aug. 26, 1964) (FDIC Proposed Regulations); id. at 12131-34 (FRB Proposed Regulations). In some respects these proposed regulations do not seem to correlate $\S 14$ (c) with those provisions dealing with the mailing of shareholder communications.

${ }^{310}$ Compare Kroese v. New York Stock Exch., 227 F. Supp. 519 (S.D.N.Y. 1964). The court there held that the New York Stock Exchange Rules do not require an issuer of securities listed on that exchange to hold regular meetings (which would require solicitation under the Exchange's rules), and that there was no such requirement under either state law or the instruments governing the organization and operation of the particular issuer involved.

${ }^{321}$ As under prior law, the period during which a stop order issued under $\S 8$ of the Securities Act is in effect is excluded for purposes of the forty and ninety day 
for registered offerings of securities of an issuer which has filed and sold pursuant to an earlier effective registration statement. However, the Amendments Act also empowers the Commission to provide, by rule, regulation or order, a "shorter period" in lieu of either the forty or the ninety day period. Undoubtedly, the power to provide "a shorter period" includes a power to eliminate the requirements. In the process of making the amendments the House Committee redesignated the various portions of section 4 , but the only substantive changes are the ones already mentioned, reflected in redesignated section 4 (3). A typographical error in the brokers' exemption ${ }^{312}$ was also corrected.

The Commission has already issued proposed Rule 174,313 shortening the period during which certain classes of securities must be accompanied by a prospectus. The proposed rule provides that in the case of offerings of securities of a listed company, the period shall be forty days. No similar provision is made for offerings of securities of section $12(\mathrm{~g})$ companies. ${ }^{314}$ For certain types of securities there would be no prospectus-delivery requirement. Under the proposed rule the delivery period for an offering pursuant to a registration statement that became effective on or before August 20, 1964, would be forty days. Proposed Rule 174 would allow the Commission to extend or shorten, within the limits set in the statute, any period specified therein or in the rule. This could be done on its own motion or upon application.

In the release accompanying proposed Rule 174, it was emphasized that the amendment did not affect the requirement of sections 4 and 5 of the Securities Act that prospectuses be delivered by an underwriter continuing to act as such, and by a dealer participating in

computations. Prior to 1954, the period was one year in all cases. I Loss 256. This amendment to the Securities Act was recommended by the Special Study as one means of dealing with "hot issues." Special Study, pt. 1, at 558. The amendment departs from the Special Study recommendation insofar as it applies to the first offerings of any security, not just common stock. The legislative history and proposed Rule 174 are silent on the effect of the amendment where the issuer has gone through mergers or other reorganizations. See note 313 infra.

${ }^{312}$ Formerly $\S 4(2)$.

31s SEG Securities Act Release No. 4726, Sept. 15, 1964.

${ }^{314}$ Many $\$ 12(\mathrm{~g})$ companies have, of course, made a prior registered offering, in which case the maximum period will be forty days. The Special Study recommended that the prospectus-delivery requirement with respect to dealers which are not underwriters or members of the selling group be eliminated for listed and $\S 12(\mathrm{~g}) \mathrm{com}$. panies. Special Study, pt. 1, at 594-95, 558. Note the Commission's cautious comment on this recommendation. House Hearings, pt. 1, at 31 . 
the distribution, ${ }^{315}$ regardless of the elapsed time since the commencement of the offering. Indeed, this is also written into proposed Rule 174. The release also emphasizes that issuers and underwriters should recognize a duty to make the prospectus available to dealers during the required period. Offices of underwriters, selling group members, the issuer, marketmakers in the security, the transfer agent and the registrar are suggested as convenient depositories.

In the same release in which proposed Rule 174 was published, the Commission proposed new Rule 425A, which would require that the outside cover of each prospectus include a statement of the period prescribed by section $4(3)$ and Rule 174 during which all dealers must use a prospectus. This is intended to apprise dealers more readily of their statutory obligation. ${ }^{310}$

\section{III}

\section{IMPROVED QUALIFICATIONS AND CONTROLS FOR Broker-Dealers and Their Associated Persons}

The second part of the Amendments Act-sections 2, 6 (a), 6(b), and 7, amending sections 3 (a), 15 (a), 15 (b), and $15 \mathrm{~A}$, respectively, of the Exchange Act-deals primarily with broker-dealers and their principals, salesmen, and other associated persons. For the most part these amendments relate to firms doing an over-the-counter securities business and their personnel. The amendments require higher qualifications for personnel and provide increased and refined disciplinary controls. In addition to affecting firms doing solely an over-the-counter business, the amendments affect most exchange members, since members frequently engage in an over-the-counter business.

Before discussing this second part of the Amendments Act in any detail, it may be helpful to outline sections $15(\mathrm{a}), 15(\mathrm{~b})$, and $15 \mathrm{~A},{ }^{317}$

\footnotetext{
${ }^{315}$ That is, a dealer effecting transactions in securities constituting part or all of an unsold allotment to, or subscription by, such dealer as a participant in the distribution.

810 The Special Study found widespread misunderstanding as to the statutory requirements. Special Study, pt. 1, at 548-50. Earlier in 1964, the Commission issued a release summarizing the "limitations upon, and responsibilities of, underwriters and dealers in the offer and sale of an issue of securities prior to and after the filing of a registration statement." SEC Securities Act Release No. 4697, May 28, 1964.

${ }_{017}$ For brief background discussions of broker-dealer regulation under the Exchange Act, see Senate Report 38-41; House Hearings, pt. 1, at 205-11. For more complete treatments, see Special Study, pt. 1, chs. II, III; id., pt. 4, ch. XII; 2 Loss chs. 7 8A.C; 3 id., ch. 9; Loomis, The Securities Exchange Act of 1934 and the Investment Advisers Act of 1940, 28 Geo. WASH. L. REv. 214 (1959).
} 
and the more important changes made in these sections by the Amendments Act.

Section 15 (a) provides that, with two exceptions, no broker-dealer shall use the mails or means or instrumentalities of interstate commerce to do any over-the-counter securities business, unless such broker-dealer is registered with the Commission. The only change made in section 15 (a) by the Amendments Act is the addition of an express Commission exemptive power.

Under prior law section $15(\mathrm{~b})$ specified that, after notice and opportunity for hearing, the Commission could, if it found it in the public interest, deny or revoke a firm's registration-thus excluding it from most facets of the over-the-counter business-if the firm or any person associated with it had committed certain acts (including a willful violation of the Securities Act or the Exchange Act or rules promulgated under either), had been convicted of certain enumerated crimes, or was subject to certain specified types of injunctions. The Amendments Act revamps and expands section 15(b), adding several provisions not strictly germane to the registration process or requirements for registration.

Section 15A, added by the Maloney $\mathrm{Act}^{318}$ in 1938, governs the registration and operation of registered securities associations. These are organizations comprised of over-the-counter broker-dealers registered with the Commission under section 15 (b). At present the NASD is the only association registered with the Commission, and, as of June $30,1963,4,664$ of the 5,423 broker-dealers registered with the Commission were members of the NASD. ${ }^{310}$ The NASD provides self-regulation in the over-the-counter market comparable to that furnished by the exchanges in the exchange markets. ${ }^{320}$ The NASD has almost unlimited powers to prescribe rules concerning the business conduct of its members, powers that in several respects are probably broader than the analogous Commission powers under sections such as $10(\mathrm{~b}), 15$ (c) (1), and 15 (c) (2) to promulgate antifraud rules applicable to all over-the-counter broker-dealers. ${ }^{321}$ The NASD operates, as provided in section 15A, under pervasive Com-

\footnotetext{
${ }^{318}$ Securities Exchange Act of 1934, amendments (Maloney Act), 52 Stat. 1070 (1938), as amended, 15 U.S.C. $§ 780-3$ (1958), as amended, 15 U.S.C. $§ 78 d-1$ (b) (Supp. $\mathrm{V}, 1964)$.

${ }^{810} 29$ SEC ANN. REP. 68, 172 (1963). A substantial number of the nonmembers may be inactive. Cf. Senate Hearings 44.

${ }^{820}$ See Special Study, pt. 4, ch. XII.G.2.

${ }^{221}$ For a detailed discussion of new $\$ 15$ (b) (10), see text following note 406 supra.
} 
mission oversight. Since all NASD members are registered with the Commission, they are regulated by both agencies. The Amendments Act makes a number of important changes in section 15A.

One important change in section $15(\mathrm{~b})$ is the addition of sections 15 (b) (8)-(10). These sections give the Commission additional powers over "nonmembers"-registered broker-dealers who are not members of an association. These new provisions allow the Commission: (1) to impose qualifications and business conduct rules (going beyond antifraud rules) on nonmembers and their personnel equivalent to those which can be imposed by an association on its members, and (2) to levy fees on nonmembers to defray the costs of the additional Commission regulation required because of their nonmembership.

The Commission had proposed that all firms doing any over-thecounter business ${ }^{322}$ be required to be members of a registered securities association. The Senate so provided, and the House Subcommittee retained the requirement. ${ }^{323}$ The provision had generated hot opposition, however, and the House Committee deleted it, ${ }^{324}$ inserting instead sections 15 (b) (8)-(10).

The Commission had pointed out that in two respects nonmembers were subject to less regulation than members. First, as noted earlier, the NASD's powers over the business conduct of its members are probably broader in several areas than the Commission's antifraud powers. Secondly, the Commission was without power to impose standards for qualifications such as training, experience, and knowledge. The NASD had such powers, and another portion of the Amendments Act authorizes and directs increased NASD standards. Finally, the Commission noted that the costs of self-regulation are borne by those regulated, rather than by the taxpayers generally. Due to the advantages of self-regulation, the Commission proposed that all over-the-counter firms be required to be members of an association. The House Committee ended the disparity between regulation and costs of members and nonmembers, but did

\footnotetext{
${ }^{322}$ Firms dealing exclusively in exempted securities, commercial paper, bankers' acceptances, or commercial bills would have been excepted.

${ }^{323}$ Under the House Subcommittee print, exclusively intrastate firms, in addition to the firms enumerated in note 322 supra, would have been exempted.

${ }^{326}$ For significant Commission statements concerning the required membership proposal, sce SENATE REPORT; House REPORT; Senate Hearings 264-67; House Hearings, pt. 2 , at $733-44,773-98,836-50,1216-19,1230-35$.
} 
so by the addition of sections $15(\mathrm{~b})(8)-(10)$, a set of provisions applicable only to nonmembers and their associated persons.

The rest of the changes in section 15 (b) affect both nonmembers and members. One important change is the expansion of the list of disqualifications upon which the Commission may deny or revoke registration or, under another change made by the Amendments Act, suspend registration for up to twelve months or censure the firm in lieu of revocation. These changes are found in new section 15 (b) (5), a thoroughly rewritten version of the first part of the last paragraph of prior section $15(\mathrm{~b})$.

An administrative sanction consisting of suspension or barring the right of any person to be associated with a broker-dealer is contained in new section 15 (b) (7). The sanction can be applied, in general, to any person who possesses a disqualification enumerated in section 15 (b) (5) that would bar his registration as a brokerdealer. Once the sanction is applied, association with any brokerdealer is illegal, without Commission consent. Violations can be dealt with by criminal, injunctive, and administrative sanctions against the person and any broker-dealer with whom he is associated. In addition, a person subject to such an order may be refused registration as a broker-dealer by the Commission. The main uses of this sanction probably will be to make persons associated with registered broker-dealers parties to administrative proceedings against their firm, to provide specific sanctions for use against wayward persons associated with such firms, and to allow an administrative proceeding directed solely against a violating associate where it is clear that his firm should not be joined. But the section has such sweep that it appears to give the Commission an effective new administrative remedy for use against all broker-dealers and their associated persons, regardless of whether the broker-dealer is registered.

New section 15 (b) (4) dispenses with the requirement, wherever it may be specified in the Exchange Act, of use of the mails or any other jurisdictional facility as an element in any violation of the Exchange Act by a registered broker-dealer or any person acting on his behalf.

The provisions of section 15 (b) governing the mechanics of registration are amended in only a few respects and are redesignated as paragraphs (1), (2), (3), and (6) of amended section $15(\mathrm{~b})$. Many of the amendments to section 15A, which directly affects 
only the NASD, its members, and their personnel, are analogous to the amendments to section 15 (b). New section $15 \mathrm{~A}$ (b) (5) authorizes and directs associations to have specified and appropriate qualifications standards for members and their associated persons. The NASD had already adopted some qualifications rules under other provisions of section 15A. Thus, the authorization portion of the new section partially duplicates pre-existing powers. Perhaps more important is the direction, which represents a Congressional demand for improved standards. Section $15(\mathrm{~b})(8)$, by design, closely parallels section I5A (b) (5). When new section 15A (b) (5) was added, former section $15 \mathrm{~A}$ (b) (5) was redesignated section $15 \mathrm{~A}$ (b) (6), and the paragraphs following that section were redesignated accordingly.

Section $15 \mathrm{~A}(\mathrm{~b})(4)$, which enumerates the grounds upon which an association must deny membership or expel from membership absent Commission approval or direction of admission or continuance, is expanded to include additional grounds. Section 15A (b) (3) is altered to allow an association, in denying or excluding a brokerdealer from membership, to give greater collateral effect to disciplinary action by exchanges for violation of any exchange rules.

Associations are empowered to proceed, when appropriate, solely against associated persons for their violations of association rules. At the same time, additional express procedural safeguards concerning specific association disciplinary and other action against associated persons are provided. Changes are also made in the Commission's review powers and procedure.

Associations are expressly authorized and required to have rules concerning over-the-counter quotations. These rules must be designed to produce fair and informative quotations and to prevent fictitious and misleading quotations.

The Senate Committee and the House Subcommittee and Committee made numerous technical and editorial changes in the second part of the Amendments Act during its travels through Congress, and, in addition to required membership, another important Commission proposal was rejected. The Commission had proposed that the existing exemption from the registration requirement of section I5 (a) for "exclusively intrastate" broker-dealers be repealed. The Senate agreed, but the House Subcommittee deleted the repeal, and the Amendments Act does not affect that exemption. The House Report emphasizes, however, that the rejection of the Commis- 
sion's proposal does not affect the Commission's powers over intrastate firms under sections such as 10 (b) and 15 (c). ${ }^{325}$ Furthermore, as we will see, section 15 (b) (7), which empowers the Commission to proceed against associated persons, probably gives the Commission an administrative sanction for use against errant intrastate broker-dealers and their personnel.

The most significant changes made by the second portion of the Amendments Act are probably those authorizing and directing the Commission and the NASD to impose qualifications standards. Never before have there been, at the federal level, express requirements of standards for qualifications in areas such as training, experience, and knowledge for persons in the securities business. Because of the broad, general language of the new provisions and the absence of any concrete legislative history on the point, it is difficult to predict what standards will be adopted. It is clear, however, that Congress directed that there be improvements. Perhaps the Special Study's chapter on qualifications ${ }^{320}$ is the best material upon which to base an estimate of the new standards that may be adopted.

With two exceptions, the provisions of the second part of the Amendments Act became effective upon enactment. The amendment to section 15 (a) became effective as of July $1,1964,{ }^{327}$ and the amendments to section $15 \mathrm{~A}(\mathrm{~b})$, in effect, became effective on the same date. Ironically, the July 1, 1964, effective date for these two sections was originally intended to provide a delayed effect, but the final result was retroactivity-happily without any serious adverse consequences.

A more detailed discussion of the second part of the Amendments Act follows.

\section{A. New Definitions}

Because most of the amendments to sections $15(\mathrm{~b})$ and $15 \mathrm{~A}$ deal with employees and other persons associated with a brokerdealer, repeated references to such persons were required. As a drafting convenience, two new definitions were added specifying the classes of persons to which the various parts of sections $15(\mathrm{~b})$ and

\footnotetext{
${ }^{325}$ HOUSE REPORT 12. For significant Commission statements concerning the proposal to remove the intrastate exemption, see SENATE REPORT; House RePORT; House Hearings, pt. 1, at 289-91, 332; id., pt. 2, at 733.44, 774-75, 1400.

320 Special Study, ch. II.

${ }^{327}$ Sec Securities Acts Amendments of $1964, \S 13$ (2), Pub. L. No. 467, 88th Cong., 2d Sess. (Aug. 20, 1964).
} 
15A apply. ${ }^{328}$ Thus, these new definitions are of vital importance in evaluating the impact of many of the amendments to those sections.

New section 3 (a) (18) adds the term "person associated with a broker or dealer." The term is defined as "any partner, officer, director, or branch manager of such broker or dealer (or any person occupying a similar status or performing similar functions), or any person directly or indirectly controlling or controlled by such broker or dealer, including any employee of such broker or dealer." The definition includes the same classes of persons enumerated in section 15 (b) before the Amendments Act whose misconduct could result in disciplinary action against the firm. ${ }^{329}$ Section 3 (a) (18) also states that for purposes of section 15 (b) (other than paragraph (7) thereof), persons associated with a broker or dealer "whose functions are clerical or ministerial" shall not be included in the meaning of such term. This exception results in unimportant contractions of the Commission's existing powers to discipline a broker-dealer for misdeeds of an associated person and has other effects in section 15 (b)..$^{330}$

Section 3 (a) (18) also allows the Commission to classify persons, including employees, controlled by a broker-dealer for purposes of any portion of the Exchange Act. This probably adds little, if anything, to the Commission's long-standing classification powers under section 23 (a).

New section 3 (a) (21) defines the new term "person associated with a member" to mean a person who is registered with a securities association registered under section $15 \mathrm{~A}$ or who is "associated with a broker or dealer which is a member of such association."331

We shall use "associated person" to mean a "person associated with a broker or dealer" or a "person associated with a member," as the context indicates. An associated person is usually an individual, but a corporation, partnership, association, joint stock com-

328 The new definitions are added by Securities Acts Amendments of 1964, $\S 2$, Pub. L. No. 467, 88th Cong., 2d Sess. (Aug. 20, 1964).

${ }^{330}$ The Commission's position has been that an employee is a controlled person: See 2 Loss 1315. See also Senate Report 72, 77; House Report 13.

${ }^{300}$ The bills as introduced would have required the Commission "appropriately" to exclude such persons. The Senate Committee amended the provision slightly. SENATE REPORT 54. The House Committee wrote the exclusion into the statute.

${ }^{331}$ The two-pronged definition allows an association to retain disciplinary juris: diction over a registered person who has terminated his association with the firm while a disciplinary proceeding was pending against him. SENATE REPORT 72; House Hearings; pt. 1 , at 223 . See also note 457 infra and accompanying text. 
pany, business trust, or unincorporated organization can also be an associated person. ${ }^{332}$

Other new provisions are added to section 3 (a) to define terms used in amended section 15 (b) (5)..$^{333}$

\section{B. Power to Exempt from Registration}

The Amendments Act ${ }^{334}$ expressly empowers the Commission to exempt broker-dealers from the registration requirement of section 15 (a). Such exemptions may be effected by rules, regulations or orders, and may be either unconditional or upon specified terms and conditions or for specified periods. The Commission has heretofore provided certain exemptions pursuant to its powers under other provisions of the Exchange Act. ${ }^{335}$ Statements by the Commission, however, imply that no wholesale use of the new power is planned, and that the primary anticipated use is in cases where it is unclear whether registration is required and the Commission is willing to sanction non-registration. ${ }^{336}$ Indeed, although the exemptive language of section 15 (a) appears to give the Commission broad discretionary powers, the Senate Report specifically speaks of an exemption only in such a limited situation. ${ }^{337}$ Moreover, the fact that many of the Commission's powers and controls apply only to reg. istered broker-dealers may tend to produce a restrictive Commission policy in this respect.

\section{Intermediate Disciplinary Powers over Registered Broker-Dealers}

The Commission is authorized, ${ }^{338}$ in lieu of revocation, to censure or suspend (for up to twelve months) the registration of a broker-

\footnotetext{
${ }^{332}$ Securities Exchange Act of 1934, § 3 (a) (9), 48 Stat. 883, 15 U.S.C. $\S 78 \mathrm{c}$ (a)(9) (1958).

${ }^{333}$ Securities Exchange Act of 1934, $\S 3(a)(19)-(20)$, added by Pub. L. No. 467 (Securities Acts Amendments of 1964), 88th Cong., 2d Sess. $\$ 2$ (Aug. 20, 1964). The definition of insurance company in $\S 3(a)(19)$ is also important for purposes of new $\$ 12$ (g).

334 Securities Exchange Act of 1934, $\S 15$ (a), amended by Pub. L. No. 467 (Securitics Acts Amendments of 1964), 88th Cong., 2d Sess. § 6 (a) (Aug. 20, 1964).

${ }^{335}$ See, e.g., SEC Securities Exch. Act Release No. 5790, Oct. 10, 1958, adopting Rule

15a-3 under powers conferred by Exchange Act $\$ \S 3$ (a) (12), 15 (a), 23 (a).

${ }^{330}$ Senate Hearings 361; House Hearings, pt. 1, at 224.

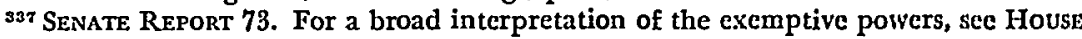
REPORT 20.

${ }^{338}$ Securities Exchange Act of 1934, $\S 15$ (b) (5), amended by Pub. L. No. 467 (Securities Acts Amendments of 1964), 88th Cong., 2d Sess. $\$ 6$ (b) (Aug. 20, 1964).
} 
dealer subject to any of the disqualifications enumerated in section 15 (b). Under prior law no intermediate sanctions were authorized, although a measure of flexibility had sometimes been attained through conditional withholding of revocation. ${ }^{339}$ The new express intermediate sanctions do not limit the Commission's use of conditional withholding of revocation or conditional granting of registration in connection with denial proceedings. ${ }^{340}$ Once a suspension has been entered, the Commission may, in its discretion, lift, shorten or modify the suspension for good cause shown. ${ }^{341}$

D. Changes in Grounds for Commission Disciplinary Action against Broker-Dealers

The Amendments Act makes significant changes in the grounds upon which the registration of a broker or dealer can be denied, revoked, or suspended, or upon which a censure may be entered. For the most part these grounds are broadened, but because of the definition of "person associated with a broker or dealer" in section 3 (a) (18), the Commission's power to discipline a firm for the misdeeds of an associated person whose functions are clerical or ministerial is narrowed. The Commission's power to act because of pre-employment disqualifications of employees is also contracted.

\section{Broadening of Disqualifications}

Before the Amendments Act, the first part of the fourth paragraph of section $15(b)$ required the Commission, after notice and opportunity for hearing, to deny or revoke the registration of a broker-dealer if it found such action in the public interest and found that the broker-dealer or any associated person was subject to certain disqualifications enumerated in clauses (A)-(D). The Amendments Act redesignates that provision as section $15(\mathrm{~b})(5)$ and expands the grounds for denial or revocation. All of the old grounds are retained in substance, clauses (A)-(D) are expanded, and new clauses $(E)$ and (F) contain further grounds permitting denial or revocation. The provisions of section 15 (b) (5) closely parallel section 203 (d) of the Advisers Act, which specifies the disqualifications under that act.

Before the Amendments Act, clause (A) covered the willful mak-

\footnotetext{
${ }^{330} 2$ LOSS 1328-33.

310 SeNATE RePORT 75; House Hearings, pt. 1, at 225.

34 Ibid.
} 
ing, or causing to be made, at any time, of a false or misleading statement with respect to any material fact in any application for registration under section $15(\mathrm{~b})$, or in any document supplemental to sucl application, or in any proceeding before the Commission with respect to such registration. Clause (A) is changed in three respects. ${ }^{342}$ First, it now refers to any report or application for registration required to be filed under any provision of the Exchange Act. ${ }^{343}$ Secondly, the reference to proceedings before the Commission concerning registration is no longer limited to registration proceedings pursuant to section $15(\mathrm{~b})$, with the result that a misstatement in a proceeding concerning registration under either the Advisers Act or the Exchange Act would appear to be a ground for Commission action. ${ }^{344}$ Thirdly, amended clause (A) specifically reaches an omission to state any material fact required to be stated. Such omissions are also covered under clause (D) (of either prior or present law) as a violation of the Exchange Act or a rule or regulation thereunder. ${ }^{345}$

Prior to amendment, clause (B) covered a conviction within ten years preceding the filing of an application for registration, or at any time thereafter, of a crime involving the purchase or sale of any security or arising out of the business of a broker-dealer. Clause (B), as revised, now also includes crimes arising out of the business of

342 Aside from misstatements in proceedings before the Commission with respect to registration, most of the grounds for denial or revocation in clause (A) wonld seem to be comprehended in clause (D) because a statutory provision or a rule providing for or requiring the filing of an application or report impliedly requires a true, accurate, and complete document. Cf. 2 Loss 1346 \& n.215, 811 \& n.82.

${ }^{343}$ Clause (A) was formerly limited to any application for registration or supplementary document under $\S 15$ (b). Unlike $\S 203$ (d) (A) of the Advisers Act, $\S 15$ (b) (5) (A) covers only reports "required" to be filed with the Commission under the Exchange Act. The CCH review interprets the "required to be filed" language as also being applicable to applications for registration as well as reports. CCH SPECIAL 24. The congressional reports seem to indicate that is not the case. SENATE REPort 75; House REPORT 21. The CCH review also assumes that applications for registration and listing of a security are included, a conclusion that is consistent with the language of the clause. CCH Spectal 24-25. In so assuming, it is implied that a listing application is "required" to be filed. In Securities Exchange Act Release No. 7430, Scpt. 10,1964 , the Commission amended Rule $15 \mathrm{~b}-2$ to state that every amendment to an application for registration under $\S 15$ (b) shall constitute a "report." This expressly fills a gap that might otherwise have resulted from the deletion in clause (A) of the reference to documents supplemental to registration applications.

3t: Cf. 2 Loss 1403 (discussion of analogous ground in Advisers Act). Conceivably, even "proceedings" (there would be some problem of defining the tcrm) concerning registration of securities, exchanges, securities associations, or other entities under any provision of the Exchange Act or any other federal securities statute would be covered.

${ }^{\text {sts }}$ See Financial Counsellors, Inc., SEC Securities Exch. Act Release No. 7371 (July 17, 1964). 
an investment adviser, crimes involving embezzlement, fraudulent conversion or misappropriation of funds or securities, and crimes that involve violation of the federal mail and communications fraud and false name statutes. ${ }^{346}$

Clause (C) was formerly applicable if the person was currently enjoined by a court from engaging in or continuing any conduct or practice in connection with the purchase or sale of any security. Clause $(C)$ is expanded under the new law to include also any injunction enjoining a person from acting as an investment adviser, underwriter, broker or dealer, or as an affiliated person or employee of any investment company, bank, or insurance company, or from engaging in or continuing any conduct or practice in connection with any such activity. ${ }^{347}$ Several of these new types of injunctions now expressly included were, of course, impliedly included in the language of prior clause (C).

Clause (D) formerly covered a willful violation, at any time, of the Securities Act or the Exchange Act or any rule under either. Clause (D) now includes, in addition, willful violations of the Investment Company Act or the Advisers Act or rules under either.

New clause (E) covers willfully aiding, abetting, counseling, commanding, inducing, or procuring the violation, by any other person, of the Securities Act, the Exchange Act, the Advisers Act, or the Investment Company Act (or rules under any of them), or the failure reasonably to supervise, with a view to preventing violations of any such statutes or rules, another person who commits such a violation. The legislative history specifies that a person will not be willfully aiding, abetting, etc., if he does not know, and has no reasonable cause to know, of the acts, omissions, scheme, or plan of the violating person. ${ }^{348}$ The failure-of-supervision ground is ap-

${ }^{360}$ The Amendments Act expressly empowers the Commission to make an administrative finding whether an offense involved or arose out of the specified activities. The Exchange Act continues to contain no definition of "convicted," although the Advisers Act defines the term for purposes of that act. Investment Advisers Act of $1940, \S 202$ (a) (6), 54 Stat. 848, I5 U.S.C. $\S 80 \mathrm{~b}-2$ (a) (6) (1958). See 2 Loss 1303-05, 1403-04.

347 The Amendments Act adds definitions of "investment adviser," "underwriter," "affiliated person," "investment company," and "insurance company" to the Exchange Act. Securities Exchange Act of 1934, $\$ \$ 3$ (a) (19)-(20), added by Pub. L. No. 467 (Securities Acts Amendments of 1964), 88th Cong., 2d Sess. $\S 2$ (Aug. 20, 1964). "Affiliated person" is given the meaning specified in the Investment Company Act, resulting in coverage of a number of affiliations and relationships. Investment Company Act of $1940, \S 2$ (a) (3), 54 Stat. 791, as amended, 15 U.S.C. $\S 80 \mathrm{a}-2$ (a) (3) (1958).

${ }^{313}$ Senate RePORT 76; House Hearings, pt. 1, at 225. 
plicable only if the violator was subject to supervision by the supervisor. Furthermore, a person will have supervised reasonably if: (1) procedures, and a system for applying them, have been established which would reasonably be expected to prevent and detect, insofar as practicable, violations by such other person, and (2) the supervisor has discharged his duties under the procedures and system without reasonable cause to believe noncompliance existed. ${ }^{39}$ Also, where there is no violation by the persons subject to supervision, a failure of supervision is seemingly not a ground for action under clause (E). ${ }^{350}$

Clause (E) does not limit the Commission's power to discipline a firm for a violation by any of its associated persons. ${ }^{361}$ It was added primarily to deal with associated persons, who literally cannot violate certain sections of the Exchange Act. This provision largely codifies the aider, abettor and failure-of-supervision doctrines which the Commission had developed to deal with associated persons. ${ }^{352}$

Clause (F) makes association with any broker-dealer by a person who is barred or suspended under new section 15 (b) (7) a ground for action against the firm. In addition, if the broker-dealer is subject to such a bar or suspension, his registration could be denied, revoked, or suspended. ${ }^{353}$

In the Commission's recommended bills the statutory cross references in clauses (B), (D), and (E) were followed by "as heretofore or hereafter amended" or similar language. The House Committee eliminated this language, and in explaining its action may have made a statement of importance in construing all the federal securities statutes. The House Committee indicated that the customary rule of construction is that such cross references apply at the time of application rather than at the time of enactment. The Committee explained that the removal of the lan-

${ }^{340}$ As the legislative history notes, a supervisory employee or principal is not, for purposes of clause (E), an absolute guarantor of the conduct of those whom lie has the power to supervise. Senate Report 76; House Hearings, pt. 1, at 226.

${ }^{360} \mathrm{~A}$ different result is obtained under the Uniform Securitics Act. See Loss AND CowetT, BLUE Sky LAw 274 (1958) (official comment to $\$ 204$ (a) (J) of the Uniform Securities Act).

${ }^{361}$ SENATE REPORT 76; House Hearings, pt. 1, at 226.

${ }^{352}$ Ibid. See, e.g., Sutro Bros. \& Co., SEC Securities Exch. Act Release No. 7052 (April 10, 1963).

${ }^{\text {sss }} \mathrm{This}$ follows from the wording of $\$ 15$ (b) (5). See also SENATE REport 78; House Hearings, pt. 1, at 227. 
guage in clauses (B), (D) and (E) involved no change of substance, and was merely intended to negate any implication that the absence of such language following other cross references was intended, contrary to the customary rule of construction, to freeze them to the date of enactment. ${ }^{354}$

Amended section $15(\mathrm{~b})(5)$ reads as though the new grounds could be applied in respect of disqualifications arising either before or after the enactment of the Amendments Act. Nothing in the legislative history is to the contrary, and the Commission appears to take that view of the section. ${ }^{355}$

As was the case before the Amendments Act, the enumerated disqualifications contain no general grounds such as "bad character." Registration with the Commission is required only of broker-dealers and not of associated persons, although section $15(\mathrm{~b})(7)$ gives the Commission greater powers over associated persons.

The Special Study had recommended that action be taken to assure by formal regulation that key personnel in the securities business possess suitable "character and integrity." 356 The Study further recommended that this be done through a system of local "character and fitness" committees, as is the case in the legal profession. ${ }^{357}$ Under new section $15 \mathrm{~A}(\mathrm{~b})(5)$, registered securities associations could so proceed with respect to their members and their employees, although there is no requirement that they do so.358 The same is seemingly true with respect to the Commission's new powers under sections 15 (b) (8)-(10) over nonmembers and their personnel. ${ }^{350}$

The Special Study also recommended a system of licensing of

354 HOUSE REPORT 22.

at5 SEC Securities Exch. Act Release No. 7425, Sept. 15, 1964, pp. 15-16; SEC Securities Exch. Act Release No. 7430, Sept. 10, 1964. Cf. J. A. Sisto \& Co., 7 S.E.C. 1102, 1103 (1940); Louis Grow, 2 S.E.C. 306 (1937) (conviction before 1936, when the language of prior $\S 15$ (b) was added). See also Fleming v. Nestor, 363 U.S. 603 (1960).

${ }^{360}$ Special Study, pt. 1, at 161 (recommendation 10).

${ }^{857}$ Ibid. The Commission's April 19, 1963 draft required such committees. See House Hearings, pt. 1 , at 654, 664-65.

${ }^{368}$ The section is probably broad enough to encompass character and integrity. The Commission's April 19, 1963 draft specifically included integrity. House Hearings, pt. 1, at $654,664-65$.

${ }_{360}$ These sections are also probably broad enough to encompass character and integrity as well as authorize the use of character and fitness committees, which presumably would be comprised of persons in the securities business and would submit reports to the Commission. Obviously, however, the use of such committees would be more difficult for the Commission than for the NASD. 
salesmen and other key securities personnel..$^{300}$ Registration of such personnel with the NASD has been required by that association in the past. Such requirements are expressly authorized under new section 15A (b) (5). The Amendments Act does not, however, expressly authorize the Commission to require registration, as such, of the associated persons of broker-dealers, although the reporting and other provisions of the Exchange Act give it ample power to keep informed about such persons and to exercise control over them. ${ }^{301}$ Narrowing of Commission's Power

The definition of associated person contained in section 3 (a) (18) provides that for purposes of section 15 (b) (other than paragraph (7)), persons associated with a broker-dealer whose functions are clerical or ministerial shall not be included within the defined term. This means that the misdeeds of clerical and ministerial persons, whether committed before or during association, will not place the broker-dealer's registration in jeopardy. ${ }^{302}$ This represents a contraction in the Commission's powers. In the bills submitted to Congress by the Commission, the Commission would have been commanded "appropriately" to exclude from section 15 (b) clerical or ministerial persons. The Senate so provided. ${ }^{g 03}$ The House Committee, however, wrote the exclusion into the statute.

The section 3 (a) (18) exclusion does not apply to section 15 (b) (7). Thus, a person barred or suspended under section $15(\mathrm{~b})(7)$ could not become associated with any broker-dealer in violation of that section, even in a clerical or ministerial capacity, without subjecting himself and the broker-dealer to the possibility of criminal and injunctive sanctions. In addition, the broker-dealer's registration would be placed in jeopardy under section $15(b)(5)(D)$, since he would be violating a provision of the Exchange Act.

The House Report narrowly circumscribes the term "clerical or ministerial." It states that ministerial is used "in the sense of act-

${ }^{300}$ Special Study, pt. 1, at 160 (recommendation 4).

sox See Special Study, pt. 1, at 69-72. Section 15 (b) (7) of course gives the Commission direct powers over associated persons. In addition, $\$ \$ 15(\mathrm{~b})(8)-(10)$ can be used by the Commission to keep informed and exercise control over associated persons of nonmembers; de facto registration with the Commission could be required.

${ }_{302}$ Two caveats must be entered. First, the broker-dealer could run afoul of $\$ 15(\mathrm{~b})(5)(\mathrm{E})$ (aiding and abetting, etc. and failure of supervision). Secondly, in order to commit many of the misdeeds specified in $\$ 15(\mathrm{~b})(5)$, a clerical or ministerial employee would have to step out of his "clerical or ministerial" role, which would probably make the exclusion inapplicable.

ses See note 330 supra. 
ing in obedience to authority without the exercise of judgment," and gives as examples, "doormen, elevator operators, clerks, and stenographers." 304

The section 3 (a) (18) exclusion will have its main effect in connection with persons who are subject to one of the disqualifications of section 15 (b) (5), but who have not been subjected to the new section 15 (b) (7) administrative sanction. For example, a person administratively adjudged by the Commission under prior section 15 (b) as a willful violator of the Exchange Act could now be employed-even knowingly-by a registered broker-dealer in a clerical or ministerial capacity without even theoretical jeopardy to the broker-dealer's registration.

Finally, the committee reports declare that the Commission is not to discipline a broker-dealer because of his employment of a person subject to a pre-employment section 15 (b) (5) disqualification, unless the broker-dealer knew, or in the exercise of reasonable care should have known, of the employee's past misconduct.365 This declaration originally appeared in the Senate Report. ${ }^{366}$ It was then incorporated into the Commission's statement to the House Subcommittee, ${ }^{367}$ and was included in the House Report. ${ }^{368}$ The Commission's statement to the House Subcommittee was to the effect that the Commission had not taken action under section 15 (b) in such cases, and that it would not do so under amended section 15 (b). ${ }^{369}$ Seemingly, this immunity would cease to be applicable where, during employment, the broker-dealer obtains actual knowledge (or information which should reasonably lead to actual knowledge) of the pre-employment disqualification. ${ }^{370}$

\footnotetext{
so4 HOUSE REPORT 13-14.

${ }^{305}$ The Senate Report appears to say that the firm is under a duty to investigate. SENATE REPORT 77. This probably means that the immunity would not be available in the absence of a reasonable investigation, even though that investigation would not have discovered the disability. The Commission's statement to the House Subcommittee states the formula in terms of a duty to investigate. House Hearings, pt. 1, at 226. The House Report, however, states that a pre-employment disqualification will not be grounds for action against the firm "unless the broker or dealer knew, or in the exercise of reasonable care should have known, of the employee's past misconduct." House REPort 22. This suggests that the immunity would be applicable where, though there is no investigation, there is no actual knowledge and a reasonable investigation would have produced none. See also note 434 infra.

s6o SENATE REPORT 77. See note 365 supra.

${ }^{307}$ House Hearings, pt. 1, at 226. See note 365 supra.

${ }^{368}$ House REPORT 22. See note 365 supra.

${ }^{300}$ House Hearings, pt. 1, at 226. See note 365 supra.

${ }^{370}$ The various discussions in the legislative history do not cover this point. For a
} 


\section{E. Modified Hearing Procedure on} Postponement of Registration

The Commission is given discretionary authority ${ }^{371}$ to expedite a hearing on postponement of the effective date of registration until final determination on denial, by limiting the hearing to affidavits and oral arguments. This change is made in section 15 (b) (6), which corresponds to the last portion of the last paragraph of prior section 15 (b). It does not affect Commission hearings concerning suspension of registration pending final determination on revocation.

\section{F. Administrative Power to Bar a Person \\ from Association with a Broker-Dealer}

New section 15 (b) (7) gives the Commission a direct, effective administrative sanction for use against persons subject to the disqualifications enumerated in section $15(\mathrm{~b})(5)$. Section 15 (b) (7) provides that the Commission may, after notice and opportunity for hearing, censure any person or suspend for up to twelve months or bar the right of any person to be associated with a broker-dealer. The sanction is conditioned upon a finding by the Commission that: (1) the person is, with a few exceptions, ${ }^{372}$ subject to any of the disqualifications set forth in section 15 (b) (5) which would prevent his registration with the Commission as a broker-dealer, and (2) the sanction is in the public interest. Once a bar, as opposed to a suspension, is entered, it apparently has perpetual life and effect.

While the order is in effect, it is unlawful for the person subject to the order willfully to become or remain associated with any ${ }^{373}$ broker-dealer without the consent of the Commission. It is also un-

discussion of the analogous immunity written into $\S 15 \mathrm{~A}(\mathrm{~b})(4)$, sce text accompanying notes $433-35$ infra.

371 SENATE RePORT 77-78; House REPORT 22. For a discussion of a similar change in $\$ 15 \mathrm{~A}(\mathrm{~g})$ during appeals pending from the NASD to the Commission, see notes 484.92 infra and accompanying text.

${ }^{372}$ Section $15(b)(5)(F)$ is not a ground for sanction. Nothing would be accom. plished by the entry of a $\S 15$ (b) (7) order merely because an earlier such order is in effect. The time reference in $\S 15$ (b) (7) concerning $\S 15(\mathrm{~b})(5)(\mathrm{B})$ (which was changed by both the Senate and the House Committees) is not precisely the time reference contained in the latter section.

${ }^{373}$ The section itself refers to "a" broker-dealer. The Senate Report refers to "any" broker-dealer, though the House Report refers to "a" broker-dealer. SENATE REPORT 79; House REPORT 22. The Commission's statements refer to "any" broker-dealer. Senate Hearings 365; House Hearings, pt. 1. at 227. In any event, the statutory schemeas shown by $\S 15$ (b) (5) (F) and the proscription in the last portion of the second sentence of $\S 15$ (b) (7)-contemplates that once the order is entered, the intended effect is to bar association with any broker-dealer, and not just one broker-dealer designated in the Commission's order. 
lawful for any broker-dealer to allow the person to become or remain associated with him, without the consent of the Commission, provided the broker-dealer knew, or in the exercise of reasonable care should have known, of the order. A broker-dealer knowingly permitting such association subjects himself to denial, revocation, or suspension of registration under clauses (D) and (F) of section 15 (b) (5). A bar or suspension under section $15(\mathrm{~b})(7)$ prohibits association with "any" broker or dealer as defined in sections 3 (a) (4)-(5) of the Exchange Act, regardless of whether such broker or dealer is registered with the Commission under section $15(\mathrm{~b})$. For example, association with an unregistered exchange broker or dealer would be prohibited.

Criminal and injunctive action can also be used to deal with a violation of the proscription. In addition, the existence of the order empowers the Commission, under section $15(\mathrm{~b})(5)(\mathrm{F})$, to deny registration as a broker-dealer to the person subject to the order.

The primary purposes of section $15(\mathrm{~b})(7)$ are undoubtedly to allow the Commission to assess direct administrative sanctions against associated persons (including clerical or ministerial persons) of broker-dealers and to empower the Commission to do this either in one proceeding directed both against the firm and the associated persons, ${ }^{374}$ or, where it is clear that no sanction should be assessed against the firm, in a proceeding directed solely against one or more associated persons. ${ }^{375}$ Before the Amendments Act, the Commission had no specific authority to impose administrative sanctions against associated persons or to compel them to become parties to a section $15(\mathrm{~b})$ proceeding against the broker-dealer. A Commission improvisation designed to compel associated persons to become parties to proceedings against their firm was struck down by the Court of Appeals for the District of Columbia. ${ }^{376}$ The Commission continued, however, to give associated persons notice and opportunity to become parties to any administrative proceeding against a firm where their interests might be affected by the proceeding, and the Commission made findings concerning the associated persons regardless of whether they appeared. This procedure proved fairly effective because of section $15 \mathrm{~A}(\mathrm{~b})(4)$ and the NASD's rules thereunder, and because section 15 (b) provided for denial or revocation of a

${ }^{374}$ See, e.g., House Hearings, pt. 2, at 1219.

${ }^{475}$ Ibid. See also text accompanying notes $387-88$ infra.

${ }^{370}$ Wallach v. SEC, 202 F.2d 462 (D.C. Cir. 1953); see 2 Loss 1314-23. 
broker-dealer's registration for disqualifications of any associated person. ${ }^{377}$ The procedure was indirect, however, and in most cases there was no administrative method of reaching an associated person without also proceeding against the firm, ${ }^{378}$ even where it was clear that no sanction should be imposed upon the firm. The Commission has already moved to conform its procedural rules to take account of section $15(\mathrm{~b})(7)$. $^{378 \mathrm{a}}$

Although section $15(\mathrm{~b})(7)$ will probably be used primarily against associated persons of registered firms, its reach does not appear to be limited to such persons. For example, a bar under section 15 (b) (7) could seemingly be applied against a registered broker-dealer in addition to revocation under section 15 (b) (5).379 A bar under section $15(\mathrm{~b})(7)$ would provide criminal and injunctive sanctions if the broker-dealer were to become associated with another broker-dealer in any capacity. On the other hand, a revocation under section 15 (b) (5) provides no such sanctions if the revoked broker-dealer becomes associated with another broker-dealer, although the latter, if registered, would itself become subject to revocation. Moreover, in many cases, a bar under section 15 (b) (7) literally has a more permanent effect than revocation under section 15 (b) (5). For example, if a broker-dealer's registration is revoked because of a criminal conviction for fraudulent misappropriation of funds in an activity unrelated to the securities business, the Commission would be powerless to deny his registration on that ground eleven years later. But if a section 15 (b) (7) bar is also imposed, it would appear that the Commission could deny his registration at any later date. ${ }^{380}$

Section 15 (b) (7) also expands considerably the jurisdiction of the Commission over broker-dealers not registered with the Com-

\footnotetext{
${ }^{377}$ Ibid.

${ }^{878}$ If the firm was a partnership and an exchange member, $\$ \S 3$ (a) (3) and 19 (a) (3) allowed an administrative proceeding under the latter section against any partner.

37aa SEG Securities Exch. Act Release No. 7422, Sept. 22, 1964.

${ }^{370}$ Section 15 (b) (7) literally states that an order can be entered thereunder against any "person," a term which is given an all-inclusive definition by $\S 3$ (a) (9). Although the legislative history is written in terms of the sanction being applicable primarily to associated persons, it does not negate use of the sanction against broker-dealers. As a matter of policy, the sanction should be entered against broker-dealers whenever a denial, suspension for up to 12 months, or revocation is entered. Otherwise, the associated persons against whom $\S 15(\mathrm{~b})(7)$ orders are entered will be subjected to a sterner sanction than the firm.

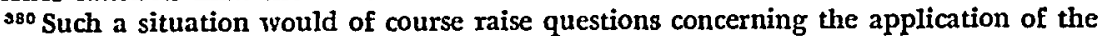
public interest test. Query whether $\S 15(\mathrm{~b})(7)$ orders should be used in this manner to obviate the time limitations in clauses (B) and (C) of $\S 15$ (b) (5).
} 
mission $^{381}$ and the associated persons of such firms. For example, if an unregistered exchange member willfully violates the Securities Act, neither section 15 (b) (5) nor section 19 (a) (3) provides administrative sanctions. Under section 15 (b) (7), however, the firm and all of its associated persons either willfully violating the Securities Act, willfully aiding or abetting the violation by other personnel in the firm, or failing reasonably to supervise other personnel who violate, could be barred. The order would not bar the firm from continuing its exchange business, since it would be a broker-dealer and its exchange activities would not make it a person associated with itself. The firm could not, however, without Commission consent, control or be controlled by another broker-dealer, and the associated persons who are barred would be precluded from being associated with the firm or any other broker-dealer. The associated persons could remain in the securities business only as sole proprietor broker-dealers doing one of the three kinds of securities businesses that section 15 (a) excludes from the registration requirement. ${ }^{382}$

A section $15(\mathrm{~b})(7)$ proceeding can also be directed against a person who has never been a broker-dealer or an associated person. For example, an independent contractor aiding and abetting a broker-dealer in a securities fraud could be the subject of a section 15 (b) (7) proceeding, either separate from or consolidated with the proceeding against the broker-dealer, and could be barred under that section. The proceeding would develop and disseminate the facts, and the order would prohibit the independent contractor from entering the securities business without the consent of the Commission. ${ }^{383}$

Disqualifications arising either before or after the enactment of the Amendments Act apparently may be grounds for invoking section $15(\mathrm{~b})(7) .384$

\footnotetext{
ss1 See note 379 supra.

${ }^{382}$ Though anomalous, it appears to be true that a person subject to a $\S 15(\mathrm{~b})(7)$ order could not, without the consent of the Commission, be associated with any brokerdealer-even one not required to be registered-but could, without Commission consent, be a broker-dealer doing one of the three kinds of securities businesses that $\$ 15$ (a) excludes from the registration requirement. This assumes that a broker-dealer simply cannot be considered to be a person associated witl itself or himself, a result that appears to follow from the statute.

333 SENATE RePORT 78-79, 88; House Hearings, pt. 1, at 227, 234. But see note 382 supra. Of course, the independent contractor might be a controlled person, and thus classified as an associated person.

sst Neither the section itself nor the legislative history restricts the disqualifications
} 
As a corollary to section $15(\mathrm{~b})(7)$, section $15 \mathrm{~A}(l)(2)$ was amended $^{385}$ to empower the Commission to suspend for up to twelve months or bar any person from being associated with a member of a registered securities association for violations of the Exchange Act, the Securities Act, or any rule under either. In light of the sweeping effects of an order under section 15 (b) (7), which are broader in several respects and narrower in none than the effects of an order under section $15 \mathrm{~A}(l)(2)$, orders under the latter section will seemingly be issued in conjunction with rather than in lieu of orders under the former. ${ }^{386}$

In hearings following the Commission's initial presentation, the House Subcommittee was critical of section 15 (b) (7). The Subcommittee members felt that the section would somehow relieve firms of responsibility for the conduct of their employees. ${ }^{387}$ The Commission, during its second presentation before the Subcommittee, emphasized that section 15 (b) (7) would not diminish the legal or moral responsibility of firms for the actions of their associated persons or lessen the duty of firms to supervise. The Commission also represented that

In nearly all cases, action will be taken against both firms and individuals. Only in the relatively unusual case where it is clear that no administrative sanction against the firm is warranted will action be taken solely against individuals, e.g., (I) where a salesman, despite proper safeguards and controls, embezzles money or other property from his firm, and (2) where a salesman commits a private securities fraud related [sic] to his firm's business. ${ }^{388}$

This apparently satisfied the House Subcommittee and Committee, as no substantive changes were made in the section.

to those arising after the enactment of the Amendments Act. See also text accompanying note 355 supra.

${ }^{385}$ Securities Acts Amendments of 1964, $\S 7$ (f), Puh. L. No. 467, 88th Cong., 2d Sess. (Aug. 20, 1964).

${ }^{386}$ Section $15 \mathrm{~A}(l)(2)$, unlike $\S 15(\mathrm{~b})(7)$, docs not spell out the effects of this ncw type of order. Moreover, an order under $\S 15 \mathrm{~A}(l)(2)$ is not one of the grounds listed in $\S 15(\mathrm{~b})(5)$, whereas a $\S 15$ (b) (7) order is. Under $\S \S 15(\mathrm{~b})(8)$ - (10), however, the Commission could probably provide that a $\$ 15 \mathrm{~A}(l)(2)$ order will preclude association with a nonmember. In one limited respect the new $\S 15 A(b)(2)$ sanction is broader than that provided by $\S 15$ (b) (7). Under $\S 15(\mathrm{~b})(7)$ a violation of the Exchange Act or a rule thereunder must be willful; under $\S 15 \mathrm{~A}(l)(2)$ such a violation need not be willful. Prior $\S 15 A(l)(2)$ also differed from prior $\S 15(\mathrm{~b})$ in this respect.

${ }^{387}$ House Hearings, pt. 1 , at $600-01,638$; id., pt. 2, at $679-82$.

${ }^{388}$ Id. at 1219. Undoubtedly "rclated" was intended to be "unrelated." See also id., pt. 1 , at 129 . 


\section{G. Jurisdictional Facilities}

Several sections of the Exchange Act, such as 10 (b) and 15 (c), prohibit conduct only when the mails or means or instrumentalities of interstate commerce are used in connection therewith. The Amendments Act removes that requirement with respect to brokerdealers registered under section $15(b)^{389}$ and "any person acting on behalf" of such broker-dealers. The removal appears to be applicable in criminal, injunctive, and private actions, ${ }^{390}$ as well as in administrative proceedings. Because of section $30(\mathrm{~b})$, the removal does not appear significantly to extend the extraterritorial reach of the Exchange Act. ${ }^{391}$

The drafting technique utilized in effecting the removal was the addition of new paragraph (4) to section 15 (b) stating that any provision of the Exchange Act that prohibits any act, practice, or course of business if the jurisdictional facilities are used, shall also prohibit such conduct by a registered broker-dealer or any person acting on his behalf, whether or not the jurisdictional facilities are used. Thus, sections such as $10(\mathrm{~b})$ and 15 (c) must be construed in conjunction with this new provision. Section $15(b)(4)$ is not applicable to sec-

${ }^{380}$ The new provision is inapplicable to members of a national securities exchange not registered with the Commission. Such a member, by definition, conducts all of its transactions on the exchange, the facilities of which are means or instrumentalities of interstate commerce. See United States v. Re, CCH FEd. SEc. L. REP. I 91,416 (2d Cir., 1964); Cady, Roberts \& Co., 40 S.E.C. 907 (1961); 3 Loss 1520 n.4.

${ }^{300}$ The wording of the statute indicates that this is the case. The justifications given by the Commission and the congressional committees deal most extensively with the problem in the context of administrative proceedings, but are broad enough to cover criminal and injunctive actions; there is no indication that the removal does not apply to criminal and injunctive actions. The rationale of the cases allowing recoveries by private parties indicates that the provision should be applicable in private actions, because the policy of sections such as 10 (b) would remain the same and the required showing of use of the jurisdictional facilities has been regarded as only a technical requirement needed to show a violation of the section or rule. See, e.g., Fratt v. Robinson, 203 F.2d 627 (9th Cir. 1953). Of course, the Commission's rules under $\S 10$ (b) are themselves tied to the use of the jurisdictional facilities; the Commission, however, has adopted a new general Rule 0-8 under the Exchange Act, which follows the language of the statutory provision and removes that tie in cases of registered brokerdealers and persons acting on their behalf. SEC Securities Exch. Act Release No. 7406, Aug. 28, 1964.

${ }^{301}$ See Kook v. Crang, 182 F. Supp. 388 (S.D.N.Y. 1960). But cf. SEC v. Gulf Intercontinental Fin. Corp., 223 F. Supp. 987 (S.D. Fla. 1963). If the Commission ever found it necessary to adopt rules under $\S 30(a)$ or $30(b), \S 15(b)(4)$ would be useful and would seem to enable it to adopt rules with far more extraterritorial effect than would otherwise be possible. For related materials on the extraterritorial reach of the federal securities laws, see 1 Loss 368-70; SEC Securities Act Release No. 4708, July 9, 1964. 
tions 5 and 15 (a), which require registration of exchanges and brokerdealers, respectively, only if the jurisdictional facilities are used.302

The term "any person acting on behalf" of a broker-dealer includes any associated person or any other person acting for the broker-dealer. For example, an independent contractor hired by a broker-dealer to do a specified task would be "acting on behalf" of the broker-dealer, even if he were not deemed an associated person of the broker-dealer. ${ }^{383}$ Seemingly, the provision applies to associated persons and others only when they are actually "acting on behalf of" the broker-dealer and not when they are acting for their own account in matters unrelated to the firm's business..$^{\mathbf{3 0 . 4}}$

\section{H. Expanded Commission Powers over Nonmember Broker-Dealers}

\section{Qualifications}

New section 15 (b) (8) empowers the Commission to prescribe "specified and appropriate" standards of "training, experience, and such other qualifications as the Commission finds necessary or desirable" for all nonmember broker-dealers (which would include an exchange member registered with the Commission but not a member of an association) and for all natural ${ }^{305}$ persons (other than clerical or ministerial persons $)^{306}$ associated with such broker-dealers. Once the standards are promulgated, a nonmember may not "effect any transaction in, or induce the purchase or sale of, any security (otherwise than on a national securities exchange)" unless the standards are met by the nonmember and all such natural associated

392 Senate Retort 74; House Report 20; House Hearings, pt. 1, at 224-25. Section 15 (b) (4) applies to any provision of the Exchange Act, whenever enacted. SENATE REPORT 74; House Hearings, pt. 1, at 224. See also the House Report stating that new $\S 15$ (c) (5), which contains the usual language proscribing conduct by broker-dealers only if the jurisdictional facilities are used, would proscribe the specified conduct by registered broker-dealers whether or not the jurisdictional facilities are used. House REPORT 24. Seemingly, the exclusion of clerical and ministerial associated persons in $\S 3(\mathrm{a})(18)$ does not affect this problem, since the term "any person acting on behalf" of a broker-dealer as used in $\S 15(b)(4)$ is broader than a "person associated with a broker or dealer." See authorities cited note 393 infra.

${ }^{393}$ SenATE REPORT 74; House Hearings, pt. 1, at 224-25; cf. House RePORT 20.

394 Authorities cited note 393 supra (by implication).

${ }^{305}$ The same limitation is contained in new $\$ 15 A(b)(5)$. See note 440 infra and accompanying text.

300 The statement in the House Report probably must yield to the language of $\S 3$ (a) (18), which excludes those persons from the definition for purposes of all of $\S$ I5 (b) other than paragraph (7). See HOUSE REPORT 13. The $\S 3(a)$ (18) exclusion does not carry over to $\$ 3($ a) (21) or I5A. 
persons. $^{307}$ The standards will not be a condition to registration. If, however, a broker-dealer remains inactive for a substantial period of time because he or his associated persons do not meet the standards, could the Commission, under section 15 (b) (6), cancel his registration?

Although the legislative history does not discuss the "other qualifications" that might be imposed under section 15 (b) (8), the section itself impliedly provides that standards of knowledge may be imposed, since the Commission is authorized to require passage of examinations. Moreover, the Commission apparently could provide that disciplinary action by national securities exchanges and associations of the type referred to in amended sections $15 \mathrm{~A}(\mathrm{~b})(3)$ and $15 \mathrm{~A}$ (b) (4) be a disqualification. ${ }^{398}$ The section purposely omits financial responsibility as a qualifications standard because of the Commission's broad pre-existing powers in that area under section 15 (c) (3).

The Commission is to set the standards by rules and regulations, which may: (A) classify brokers, dealers, and associated persons, taking into account relevant matters such as type of business and nature of securities sold; (B) provide separate standards by classes; (C) require all or any classes to pass examinations; and (D) provide that persons other than brokers, dealers, partners, officers, and supervisory employees (a term which includes branch managers and such other persons as the Commission determines) may be qualified solely on the basis of "compliance with such specified standards of training and such other qualifications as the Commission finds appropriate."

Clauses (A)-(D) closely follow clauses (A)-(D) of new section $15 \mathrm{~A}(\mathrm{~b})(5)$, which authorizes and directs associations to adopt improved qualifications standards. Because of this similarity and the fact that the legislative history states that the purpose of paragraphs $(8),(9)$, and (10) of section 15 (b) is to provide authority under which the Commission may impose regulation upon nonmembers comparable to that afforded by an association with respect to its mem-

${ }^{307}$ The House Report appears to be in error when it refers to a tie to the jurisditional facilities, since, even aside from new $\$ 15$ (b) (4), $\$ 15$ (b) (8) contains no language about the jurisdictional facilities. See House REPORT 23.

${ }^{308}$ Such action would be consistent with, or perhaps even required by, the comparability principle that runs through the legislative history. If this were done the Commission would presumably provide a procedure for case-by-case waivers of the type authorized under $\S \S 15 \mathrm{~A}(\mathrm{~b})(3)-(4)$. 
bers, ${ }^{399}$ the more complete legislative history of new section $15 \mathrm{~A}$ (b) (5) provides good background material for supplementing the legislative history of section 15 (b) (8). ${ }^{400}$ In one important respect, however, the legislative histories of the two sections conflict. Sections 15 (b) (8) (D) and 15A (b) (5) (D) read exactly the same in all relevant respects, and provide that the Commission and registered securities associations, respectively, may permit persons other than broker-dealers and key personnel to be qualified solely on the basis of training and other qualifications, omitting experience as a requirement. In discussing section 15A (b) (5) (D), the House Report, consistent with the Senate Report ${ }^{401}$ and the Commission's statements, ${ }^{402}$ says: "Thus, members, officers, partners, and other supervisory employees might be required to meet standards of experience as well as training." 403 However, in discussing section 15 (b) (8) (D), the House Report uses the following, vastly different language: "However, the Commission could not permit brokers, dealers, and their supervisory employees (which term shall be defined by the Commission) to qualify solely on that limited basis [training and knowledge alone]." 404 This indicates, without explanation for the difference, that the Commission must impose an experience standard for brokers, dealers and key personnel, while the NASD may, but need not necessarily, do so. This difference in language in the House Report was undoubtedly due to inadvertence. In light of the similarity of language in the two sections and the heavy emphasis in the legislative history on comparability, the two sections should be interpreted in the same manner on this point. Thus, the interpretation given section $15 \mathrm{~A}$ (b) (5) (D)-which was set in the Senate and followed by the House-should govern.

The approach followed in sections $15(\mathrm{~b})(8)$ and $15 \mathrm{~A}(\mathrm{~b})(5)$, while generally similar to that followed in sections 204 (a) and 204 (b) of the Uniform Securities Act, contains significant differ.

\footnotetext{
${ }^{300}$ See text accompanying notes 411-29 infra.

${ }^{100}$ For example, the Commission could undoubtedly provide appropriate grandfather clauses or transition periods, establish a procedure for passing on requests for waivers on a case-by-case basis, and establish separate requirements for dealers which primarily sell mutual fund shares, since all of this can be done under $\S 15 \mathrm{~A}$ (b)(5). See text accompanying notes 440-52 infra.

201 SENATE Report 81.

${ }^{402}$ House Hearings, pt. 1, at 229.

${ }^{03}$ House RePORT 26. (Emphasis added.)

606 Id. at 23.
} 
ences. Under the Uniform Securities Act, a person with adequate training or knowledge cannot also be required to have experience. Moreover, under that act requisite qualifications are a condition to registration; that is the case under section $15 \mathrm{~A}(\mathrm{~b})(5)$, but not under section 15 (b) (8). Both the Uniform Securities Act and the Amendments Act recognize, however, that salesmen need not have the same qualifications as a broker-dealer. ${ }^{405}$

The Commission may prescribe, by rules and regulations, reasonable fees and charges to defray the costs of carrying out section 15 (b) (8), including, but not limited to, fees for any examination it may administer. In implementing section 15 (b) (8) the Commission is authorized to cooperate with registered securities associations and national securities exchanges in administering examinations. The Commission may also require persons subject to the new provision to pass examinations administered by or on behalf of any such exchange or association, and to pay them reasonable fees for their costs of administering such examinations. For example, the Commission could work with the NASD and the exchanges, use their test centers, and prescribe passage of examinations developed by them as a qualifications standard.

\section{Fees}

Section 15 (b) (9) requires each nonmember to pay the Commission "such reasonable fees and charges as may be necessary to defray the costs of additional regulatory duties required to be performed by the Commission" because the broker-dealer is a nonmember. These fees and charges are in addition to those authorized by section 15 (b) (8), and are to be established by Commission rules and regulations. Because the fee power applies only to registered brokerdealers, there is considerable incentive for timely payment of fees. Nonpayment or late payment of any fee or charge could be grounds for suspension or revocation of registration under section 15 (b) (5) (D). ${ }^{408}$

\footnotetext{
${ }^{208}$ See LOSS AND CoWETt, BLUE SKY LAW 271-80 (1958).

${ }^{800}$ The Commission has taken such action where a broker-dealer has willfully failed to file financial reports. See, e.g., H. B. Bloch \& Co., 40 S.E.C. 375 (1960). Moreover, a failure to make and keep current the books and records required by the Commission's rules has been grounds for such action. See, e.g., Eugene N. Owens, SEC Securities Exch. Act Release No. 7370 (July 16, 1964). Under § 15 (b) (10) the Commission could probably go further and prohibit the execution of any over-the-counter securities business when fees or charges are in arrears.
} 
Section 15(b)(10)

Under new section 15 (b) (10) the Commission may prescribe, with respect to nonmembers, rules and regulations desigued: (1) to promote just and equitable principles of trade, (2) to provide safeguards against unreasonable profits or unreasonable rates of commissions or other charges, and (3) in general, to protect investors and the public interest, and to remove impediments to and perfect the mechanism of a free and open market. The drafting technique used generally follows that employed in section 15 (c) (1), a general antifraud section, in that a broker-dealer subject to such rules and regulations is forbidden to effect any transaction in, or induce the purchase or sale of, any security (otherwise than on a national securities exchange) in contravention thereof.

The language setting forth these powers is to a great extent taken from section $15 \mathrm{~A}(\mathrm{~b})(8)$ dealing with the content of the rules of an association, but does not contain several of the restrictions imposed in that section. Under section 15 (b) (10), for example, the Commission could adopt rules similar to or identical with the NASD's markup policy ${ }^{407}$ and underwriting compensation rules, ${ }^{408}$ and the NASD's general rule of fair practice to the effect that a broker-dealer shall observe just and equitable principles of trade and high standards of commercial honor. ${ }^{409}$ Indeed, section 15 (b) (10) can be used to regulate almost any securities industry practice. For example, it probably is broad enough to empower the Commission to impose qualifications standards on nonmembers and their personnel, although arguably the presence of section 15 (b) (8) might preclude the use of section $15(\mathrm{~b})(10)$ for that purpose. Even with the expanding concept of "fraud" under the federal securities laws,"10 the Commission's general prophylactic rulemaking powers under section 15 (c) (2)-the broadest antifraud section and one of general applicability to over-the-counter transactions of all broker-dealersprobably stop somewhat short of these powers.

\section{The Legislative History Gloss on Sections 15(b)(8)-(10)}

The House Report states that sections 15 (b) (8)-(10) are not to be construed in derogation of the Commission's powers under any other

${ }^{007}$ See 3 Loss 1493-97; Special Study, pt. 2, ch. VII.D.4.b; NASD Manual G-1 to G-6. ${ }^{08}$ Id., pt. I, at 512; id., pt. 4, at 661; NASD Manual G-59 to G.62.

${ }^{\circ 0}$ NASD Rules of Fair Practice, art. III, \& 1, NASD Manual D-5.

${ }^{10}$ See, e.g., SEG v. Capital Gains Research Bureau, Inc., 375 U.S. 180 (1963). 
provision of law. ${ }^{411}$ The report also states ${ }^{412}$ that the sections are designed to "insure that the Commission has the necessary authority to provide regulation of [nonmembers] . . . comparable to that imposed by associations on their membership, including the requirement that [the nonmembers] . . . pay fees which will compensate the Commission for this additional regulation." 413 This statement would seem to indicate that the House Committee intended for the authority of the Commission under sections $15(\mathrm{~b})(8)-(10)$ to be comparable to that of the NASD, and for the actual regulation to also be comparable. Comparability of regulation is, of course, different from comparability of authority because the NASD's sweeping authority is broader than its existing regulation.

These matters were again discussed in an important colloquy on the House floor between Representatives Harris and Curtin.414 The two agreed that the Commission's fees and charges under sections 15 (b) (8) and 15 (b) (9) should not be significantly higher than those assessed by the NASD. It may be inferred from this that the Commission's fees can be equal to, or slightly in excess of, the NASD's. ${ }^{415}$ The two also agreed that there should be comparability of regulation, ${ }^{418}$ although Ghairman Harris added this siguificant caveat:

\footnotetext{
411 HOUSE REPORT 24.

¿12 HOUSE REPORT 12.

${ }^{413}$ In the other places where the House Report discusses these sections, the idea of comparability is not mentioned as directly. See House REPORT 3, 23-24.

\$1 110 Conc. REc. 17326 (daily ed. Aug. 4, 1964). Representative Harris is Chairman of the House Committee.

"15 Of course, it is difficult to say with any certainty whether it will cost the Commission more or less money to accomplish, with respect to nonmembers, what the NASD does with respect to its members. An important point is that under $\S 15$ (b) (9) the reference to "additional regulatory duties" is not confined to enforcing rules under $\S \mathrm{I}(\mathrm{b})(\mathrm{I} 0)$ or performing activities which the Commission had no authority to engage in under prior law. Perhaps the simplest and fairest solution would be for the Commission to peg its fees and charges under $\S \S 15(\mathrm{~b})(8)-(9)$ to the dues and fees of the NASD. By so doing, the comparability principle would be served. These sections appear to provide the Commission with sufficient elbow room to do that, although there might be some slight imprecision. On one hand, the NASD benefits from costs and fines in proceedings, a source of revenue that will not be available to the Commission. Also, many persons contribute free services to the NASD's operation. On the other hand, the NASD incurs certain trade association expenditures that the Commission will not incur, and usually has an excess of receipts over disbursements. See Special study, pt. 4, at 641-46. Nevertheless, these factors probably come close to cancelling each other. So long as the Commission subjects nonmembers to approximately the same degree of regulation that the NASD does its members, then a close alignment of fees and charges would be proper. Indeed, the colloquy contemplates that kind of a close aligument.

"10 Representative Curtin's words were that nonmembers and members should be
} 
Obviously however, this does not contemplate that if the association were to relax its regulation of its members that the Commission then would be forced to relax its regulation of nonmembers. Each has its duties under the authority given by the bill. It is the intent that the authority to regulate be comparable and it is assumed it will be exercised by both.117

Apparently, as long as the NASD does a good job the Commission's rules under sections 15 (b) (8)-(10) are not to go substantially beyond the NASD counterparts. In the qualifications area, where the Commission can alter or supplement an association's rules, any substantial variance would raise the question why the Commission does not use its oversight powers to eliminate the variance. Naturally enough, there may sometimes be disagreement on whether the NASD is doing a good job, and it would appear that the Commission, as the NASD's overseer, would have the power to make reasonable determinations on that question.

Another aspect of comparability should not be overlooked. The legislative history of sections $15(\mathrm{~b})(8)-(10)$ in effect commands the Commission to go as far as the NASD.

This legislative history may have an important bearing in determining the effect of differences in language between sections $15 \mathrm{~A}(\mathrm{~b})$ (8) and 15 (b) (10). For example, under the broad authority of section 15 (b) (10) the Commission is empowered to promulgate rules relating, inter alia, to "exempted securities." On the other hand, section 15A expressly prohibits the NASD from so doing. 118 Therefore, can the Commission's section 15 (b) (10) rules apply to exempted securities? In addition, section $15 \mathrm{~A}$ (b) (8) prohibits an association from setting any schedule of prices, minimum commissions, or other charges. ${ }^{419}$ No such limitation is imposed by section 15 (b) (10). Is this limitation contained in section $15 \mathrm{~A}$ (b) (8) effectively written into section 15 (b) (10)?

Section 15 (b) (10) would appear, on its face, to give the Commission power to set limits on the amount of sales loads on mutual

\footnotetext{
"treated alike." As a practical matter, "comparability"-the term used in the House Report and by Chairman Harris, and which in this context appears to mean substantial equivalence-is necessarily as close a match as can be obtained.

412 110 Cong. REc. 17326 (daily ed. Aug. 4, 1964).

618 Securities Exchange Act of 1934, $\S 15 \mathrm{~A}(\mathrm{~m})$, added by 52 Stat. 1070 (1938), 15 U.S.C. $§ 780-3(\mathrm{~m})(1958)$.

419 These are only a few of the limitations appearing after the semicolon in $\S 15 \mathrm{~A}(\mathrm{~b})(8)$.
} 
fund shares sold by nonmembers. ${ }^{420}$ Does this give the Commission any greater powers than it has under the Investment Company Act ${ }^{421}$ and other provisions of law? It would appear from the legislative history that the regulatory authority of the Commission under section 15 (b) (10) would be limited to the same type of authority that the NASD possesses. That raises another nice question. Is the NASD's authority limited to that under section 22 of the Investment Company Act, or does the NASD have further authority under section $15 \mathrm{~A}(\mathrm{~b})(8)$ ?

What effect would the legislative history gloss have in the highly unlikely event that at some future date there is no association? Seemingly, the gloss would remain applicable to the extent that the Commission probably would be restrained from going any further under sections 15 (b) (8) and 15 (b) (10) than an association could go if one were registered. On the other hand, one of the primary reasons for the comparability gloss was to prevent broker-dealers from choosing between membership and nonmembership because of a disparity between Commission and NASD regulation. This justification for the comparability principle would disappear if there were no association. In that event, therefore, it might be argued that the Commission should be free to exercise fully its powers under the literal language of sections $15(\mathrm{~b})(8)$ and $15(\mathrm{~b})(10)$, powers which literally are broader in some respects than their section $15 \mathrm{~A}$ counterparts. The stickiest problem would be the setting of fees and charges under section 15 (b) (9), since the Commission would not have the handy yardstick, or at least starting point, of NASD fees. The Commission would apparently have to determine the cost of the regulation of which it would be relieved by the existence of an active, effective association.

With respect to the foregoing discussion, a letter from the general counsel of a large nonmember firm inserted in the Congressional Record for September 17, 1964, is of particular interest. The letter, which of course cannot be considered a part of the legislative history in the strict sense, outlines the nonmember's views on how these sections should be interpreted. ${ }^{422}$

\footnotetext{
420 This is by virtue, inter alia, of the power to provide safeguards "against unreasonable profits or unreasonable rates of commissions or other charges."

"21 See, e.g., Investment Company Act of 1940, $\$ 22(\mathrm{c}), 54$ Stat. 823, as amended, 15 U.S.C. $\S 80 \mathrm{a}-22$ (c) (1958).

${ }^{12} 110$ Cong. Rec. A 4736 (daily ed. Sept. 17, 1964). The letter and attachment in
} 
Despite the legislative history, in several important respects neither the authority nor the regulation can be truly comparable. The nonmembers will be subject to rules and regulations of the Commission, the violation of which will subject them to the possibility of criminal and injunctive sanctions as well as suspension or revocation of registration. These are all sanctions that are necessarily more serious than the NASD's. In addition, a NASD member who violates a rule of the association will have two chances for leniency. The Commission, in reviewing NASD disciplinary action, cannot increase the sanction applied by the NASD or find a violation where none was found by the association; it can, however, decrease the penalty imposed by the NASD. ${ }^{423}$ In contrast, a nonmember violating a Commission rule under sections $15(\mathrm{~b})$ (8)-(10) has only one opportunity (at the Commission level) for leniency. ${ }^{424}$ Moreover, even with the new flexible sanctions added by the Amendments Act, the Commission does not have the full range of flexibility that the NASD has in assessing penalties. For example, the Commission cannot impose fines. ${ }^{425}$ In a few cases this might result in a nonmember's registration being suspended for a short period by the Commission for violation of a section 15 (b) (10) rule, whereas in a similar situation, the NASD would levy a fine, in accordance with the member's preference. Furthermore, the contract voiding provisions of section 29 of the Exchange Act would be applicable when there is a violation of any Commission rule under section 15 (b) (10). Other private rights of action might also be implied. On the other hand, it is not clear whether there are any implied liabilities when a member violates a similar NASD rule. ${ }^{228}$ Finally, in case-by-case determinations the

the record appear to have been prepared previous to House consideration of the bills in August. Note the statement-which is quite erroneous in the authors' view-that fees and charges under $\S \S 15(\mathrm{~b})(8)-(9)$ should not be based on any activity for which the Commission formerly had the authority to perform. The material states that $\S 15(b)(10)$ does not enlarge the Commission's authority under the Investment Company Act over sales loads on mutual fund shares. This assumes that the NASD's authority is limited to that which it has under that act, and that the comparability principle so limits the Commission's powers under $\$ 15$ (b) (10). The material contemplates that the Commission's standards should measure up to those of the NASD.

${ }^{423}$ Securities Exchange Act of 1934, $\S 15 A(h)$, amended by, Pub. L. No. 467 (Securities Acts Amendments of 1964), 88th Cong., 2d Sess. $\$ 7$ (d) (Aug. 20, 1964) .

12s Judicial review is available for both NASD and Commission sanctions.

\$25 Of course a suspension can have an economic effect similax to a fine.

${ }^{46}$ In this respect, Congress showed that it was serious about the Commission's regulation under $\S 15$ (b) (10). Although contract voiding provisions are not applicable 
Commission would not be required to, and might not, interpret and apply its own section 15 (b) (10) rules exactly the same way the NASD will interpret its own rules, even if the two sets of rules are virtually identical.

Nothing in the Amendments Act derogates from section 15A (i), under which the NASD has adopted economic inducement rules ${ }^{427}$ which have played a substantial role in causing approximately $90 \%$ of all active, registered broker-dealers to join the NASD. ${ }^{428}$ When the foregoing considerations are coupled with the fact that the fees and charges on nonmembers and members will be approximately equal, the inevitable result will be an increase in NASD membership. Nevertheless, the solution devised by the House Committee appears salutary. Its solution meets the objection to compulsory regulation by competitors raised during the hearings. ${ }^{429}$ The solution allows nonmembers, for whom the economic inducement is not important, the choice of receiving supplementary regulation from the Commission or an association, and ensures that those who choose to remain nonmembers will bear the costs of the supplementary regulation.

The Commission's proposal of required membership was, of course, a vote of confidence in the NASD. The House Committee's action should seemingly be similarly interpreted, since that Committee contemplated that the regulation provided by the NASD should, by virtue of comparability of authority and regulation pursuant to sections $15(\mathrm{~b})(8)-(10)$, be applicable to nonmembers. The House Committee's only point of difference with the Commission and the NASD appears to have been whether there

to rules under $\S 15$ (c) (2), Congress made the voiding provisions applicable to rules under $\S 15(\mathrm{~b})(10)$. On implied rights of action for violations of the rules of selfregulatory agencies, see Colonial Realty Corp. v. Bache \& Co., CCH FED. SEC. L. REP. I 91,351 (S.D.N.Y. 1964) (held no implied right of action for violation of New York Stock Exchange or NASD rules). In Walsh v. Peoria \& Eastern Ry. Co., 222 F. Supp. 516 (S.D.N.Y. 1963), the court did not reach the question whether violation of a New York Stock Exchange rule would be the basis for an implied right of action, but indicated there would be some doubt. The question of implied rights of action for members' violations of the rules of self-regulatory agencies is somewhat different from the liability of a self-regulatory organization itself for its failure to enforce its own rules. See Baird v. Franklin, 141 F.2d 238 (2d Cir.), cert. denied, 323 U. S. 737 (1944); Klebanow v. Funston, CCF FED. SEC. L. REP. ๆ 91,421 (S.D.N.Y. 1964); Kroese v. New York Stock Exch., 227 F. Supp. 519 (S.D.N.Y. 1964); Petitt v. American Stock Exch., 217 F. Supp. 21 (S.D.N.Y. 1963).

¿27 See 2 Loss 1369-70.

428 Senate Hearings 44.

${ }_{400}$ House Hearings, pt. 2, at 836-49. 
should be direct legal compulsion to join an association. Although Congress in 1938 had taken the crucial and unique step of authorizing economic inducements which have made membership a practical economic necessity for many firms, the House Committee was unwilling to take the final step of imposing an outright legal requirement of membership for all broker-dealers.

Implementation of Sections 15(b)(8)-(10)

The Commission recently sent a questionnaire to all nonmembers requesting comprehensive information concerning the nature and scope of their business. This information is to provide a basis for the Commission's rules under these sections. ${ }^{120 a}$

\section{Miscellaneous Changes in Section $15(b)$}

The first three unnumbered paragraphs of pre-existing section 15 (b) are designated as paragraphs (1), (2), and (3), respectively, and a few editorial changes are made. In addition, in paragraphs (1) and (2) the defined term "person associated with a broker or dealer" replaces the language "person directly or indirectly controlling or controlled by, or under direct or indirect common control with, such broker or dealer" in provisions specifying the persons about whom the Commission may require information in registration applications.

In two respects, this change may restrict the class of persons about whom information can be required under section $15(\mathrm{~b})$ in registration applications. Information perhaps cannot be required about "clerical or ministerial" persons associated with the firm or about persons under "direct or indirect common control with" the firm. Once a firm is registered, however, information about those persons could seemingly be required under the reporting provisions of section 17, and section 23 (a) seemingly provides authority to require information about all such persons in registration applications. ${ }^{430}$

\footnotetext{
\$20a SEC Securities Exch. Act Release No. 7446, Oct. 20, 1964.

${ }^{40}$ The change in paragraphs (1) and (2) removes the disparity formerly cxisting in $\S 15$ (b) between the several references therein to the various classes of persons affiliated with a broker-dealer. The Commission has amended its registration form, Form $\mathrm{BD}$, and Rule $15 \mathrm{~b}-2$ as a result of the Amendments Act. See SEC Securities Exch. Act Release No. 7430, Sept. 10, 1964. In the revised Form BD, registered brokerdealers are required to supply information about clerical and ministerial persons; this is apparently pursuant to the authority of $\S 17$ (a). Furthermore, new registrants are rcquired to furnish information about those associated persons, though $\S 15$ (b) no longer gives the Commission the power to so require. However, the Commission noted
} 
J. Disqualifications from Membership in an Association

Before the Amendments Act, section 15A (b) (4) required the rules of an association to provide that, except where the Commission otherwise approves or directs, no broker or dealer be admitted or continued in membership if the firm or any associated person: (A) has been and is suspended from a registered securities association or from a national securities exchange for violation of any rule of either relating to conduct inconsistent with just and equitable principles of trade; or (B) is subject to a Commission order denying or revoking his registration as a broker-dealer or expelling or suspending him from membership in a registered securities association or a national securities exchange; or (C) by his conduct while an associated person of a broker-dealer was a "cause" of any suspension, expulsion, or order described in the foregoing clauses which is in effect with respect to the broker-dealer.

Taking cognizance of the new, direct disciplinary powers given the Commission and registered securities associations over associated persons, the Amendments Act adds orders suspending or barring association with broker-dealers entered by those agencies to clauses (A) and (B). Also added to those clauses is the new Commission sanction of suspension of registration as a broker-dealer firm, and action by a national securities exchange in barring or suspending a person from being associated with all members of the exchange. 431

The Commission, registered securities associations, and national securities exchanges are expressly authorized to make "cause" determinations under clause (C), which they had been doing under the implied authority in that clause. ${ }^{432}$ Because of the additional sanctions for use against associated persons given the Commission and associations by the Amendments Act, and because of the expansion of clauses (A) and (B) to cover these sanctions and similar sanctions by a national securities exchange, it will seldom be necessary for the Commission and the self-regnlatory agencies to make

\footnotetext{
$\$ 23$ (a) as one of its sources of authority; it seems proper to require information under that section about such persons initially, since, under $\$ 17$ (a), information could be required once the firm is registered. Neither the former nor the revised form requires information about persons under direct or indirect common control with the firm.

${ }^{431}$ See also NASD By-laws, art. I, § 2 (a) (D), NASD Manual C-6; id., art. XV, 3 (b), NASD Manual C-54. Clauses (D)-(F) of art. I, $\S 2$ (a) were adopted pursuant to $\$ 15 \mathrm{~A}(\mathrm{~b})(3)$. 2 Loss 1377.

¿32 For a discussion of the "cause" concept, see 2 Loss 1384-85.
} 
"cause" determinations under clause (C). Retention of clause (C) was necessary, however, to maintain the effectiveness of prior "cause" determinations.

While section $15 \mathrm{~A}(\mathrm{~b})(4)$ is significantly expanded by the above changes, its application is restricted by the addition of language in new clause (D) providing that a disqualification under clause (A), (B) or (C) relating to an associated person will be grounds for action against the broker-dealer only if it is also shown that while such person was associated with the firm, the firm knew, or in the exercise of reasonable care should have known, of the disability. ${ }^{433} \mathrm{Al}$ though this provision was added primarily to deal with pre-employment disqualifications of employees, a literal construction would apparently include disqualifications of all associated persons, whether arising before or during association with the firm. ${ }^{434}$ The effect of this amendment is similar to the effect of the legislative history under section 15 (b) (5) restricting the Commission's power to take action against firms because of pre-employment disqualifications of employees. ${ }^{435}$

Anomalously, the "clerical or ministerial" proviso in section 3 (a) (18) does not carry over to any part of section 15A, with the result that clerical or ministerial associated persons are covered by section $15 \mathrm{~A}$ in its entirety.

Section $15 \mathrm{~A}$ (b) (3) is amended to empower an association to adopt a rule under which it may refuse the admission or continuation in membership of any broker-dealer if the broker-dealer, or any associated person, has been and is suspended or expelled from membership in a national securities exchange, or is barred or suspended from being associated with all members of such an exchange for the

¿ss The provision was added by the Senate Commitlee. The House Committce recast all of $\S 15 A$ (b) (4), apparently with no intent of changing the substance of the Senate version. See HOUSE REPORT 13, 25.

${ }^{4 *} \mathrm{By}$ the very nature of the disqualifications in $\S 15 \mathrm{~A}(\mathrm{~b})(4)$, however, the firm would, in the exercise of reasonable care, almost invariably know of the disability whether it arose before or during association. Cf. Vickers, Christy \& Co., SEC Sccurities Exch. Act Release No. 6872 (Aug. 8, 1962) (NASD memher is under a duty to make a reasonable investigation of a prospcctive salesman's character and reputation).

${ }^{435}$ See discussion of $\$ 15$ (b) (5), text accompanying notes 342-61 supra. As a purcly technical matter, the NASD perhaps would not be required to write the immunity into its rules, for $\S 15 \mathrm{~A}$ (b) (4) sets minimum disqualifications that must be contained in the rules and does not limit the use of $\$ \S 15 \mathrm{~A} \mathrm{(b)} \mathrm{(3)} \mathrm{and} \mathrm{(5)} \mathrm{for} \mathrm{the} \mathrm{adoption} \mathrm{of} \mathrm{more}$ stringent disqualifications. This immunity is, however, so much in accord with basic fairness that it should be adopted, especially since the committee reports provide a similar immunity under $\$ 15(\mathrm{~b})$. 
violation of any rule of such exchange. An association rule of this nature must give the Commission power to overrule the association and direct admission to or continuance in membership. This amendment allows an association rule that will give greater effect to exchange disciplinary action than does section $15 \mathrm{~A}(\mathrm{~b})$ (4) (A), which is applicable only if the exchange rule violated is one pertaining to just and equitable principles of trade. This amendment also differs from section $15 \mathrm{~A}(\mathrm{~b})(4)(\mathrm{A})$ in that the former allows an association to have a rule whereunder exclusion is discretionary, whereas the latter requires that exclusion be mandatory under an association rule. Thus, an association rule adopted under section $15 \mathrm{~A}$ (b) (3) would have no bearing on exchange suspensions or expulsions which clearly involve conduct inconsistent with just and equitable principles of trade, since in such instances section $15 \mathrm{~A}(\mathrm{~b})(4)$ (A) would require exclusion from membership unless the Commission orders otherwise. ${ }^{436}$

This amendment was adopted because in many instances it is uncertain whether disciplinary action taken by securities exchanges is predicated upon a rule relating to just and equitable principles of trade. The NASD did not attempt to characterize exchange action where the exchange did not do so. ${ }^{437}$

The legislative history writes several safeguards into the provision. An association rule adopted under this new provision may exclude a broker-dealer from membership because of an exchange suspension or expulsion only if the action resulted from "serious misconduct of a nature affecting the public interest and the protection of investors." The association can determine the basis for the suspension or expulsion where it is not clear from the exchange's action. The brokerdealer is also entitled to a hearing before the association if he alleges that he has not received a fair hearing before the exchange. In addition, the Commission must consider and pass upon any request that it direct a continuation or admission to membership if the person alleges either the absence of a fair hearing by the exchange or that the grounds on which the exchange acted do not justify his exclusion from the association. ${ }^{438}$

Again it appears that the expanded grounds for disqualification under amended sections $15 \mathrm{~A}(\mathrm{~b})(3)$ and $15 \mathrm{~A}(\mathrm{~b})(4)$ are applicable to

\footnotetext{
${ }^{100}$ SEC Securities Exch. Act Release No. 7425, Sept. 15, 1964, p. 19.

${ }^{187}$ SENATE REPORT 79-80; House Hearings, pt. 1, at 228.

18 Ibid.
} 
disqualifications occurring either before or after the effective date of the Amendments Act. ${ }^{438}$

\section{K. Association Qualifications Standards}

Under new section $15 \mathrm{~A}$ (b) (5), associations are required to adopt specified and appropriate standards concerning training, experience, and other qualifications of members and natural ${ }^{440}$ persons associated with members. For this purpose, members and other persons are to be appropriately classified and the standards applicable to each class specified. Persons in appropriate classifications are to pass examinations. The standards are also to identify those classes of persons (not to include prospective members, partners, officers, and supervisory employees) who may be qualified solely on the basis of training and other qualifications. The enumerated key persons may be required to meet standards of experience as well as other qualifications. ${ }^{441}$ Associations must also establish standards of financial responsibility for members.

Though section $15 \mathrm{~A}$ (b) (5) appears to be drafted in terms of imposing qualifications standards only on new members and associated persons, the legislative history clearly shows that the section was intended to allow an association to impose such standards on all members and natural associated persons. ${ }^{42}$ These requirements closely parallel the Commission's new qualifications power over nonmembers and their associated persons in section 15 (b) (8). One minor difference is that section $15 \mathrm{~A}(\mathrm{~b})(5)$ reaches all associated persons, including those whose functions are clerical or ministerial, whereas section $15(\mathrm{~b})(8)$ does not apply to clerical or ministerial associated persons.443 As is the case with section $15(\mathrm{~b})(8)$, the "other qualifications" are not specified, although knowledge is

\footnotetext{
${ }^{130}$ See notes 355 and 384 supra and accompanying text.

«10 The Commission's April 19, 1963 draft did not limit the scope to "natural" associated persons. See House Fearings, pt. 1, 664-65. For discussion of the effects of the limitation, see Senate Hearings 366-67; SENATE RePORT 81, 87; House Hearings, pt. 1, at $229,233$.

"1 See note 404 supra and accompanying text.

"12 Senate Report 43-44, 81-82; House Report 2, 25-26. The discussion in the committee reports and the Commission's materials of grandfather clauses and transition periods would be unnecessary if the section allowed the NASD to impose requirements only on new members and registered representatives. There is no similar question under $\S 15(\mathrm{~b})(8)$, which contains a different drafting technique not tied to registration. Presumably, $\S 15 \mathrm{~A}(\mathrm{~b})(5)$ does not decrease an association's authority under $\S 15 \mathrm{~A}(\mathrm{~b})(3)$-and possibly $\S 15 \mathrm{~A}$ (b) (8)-to impose, for example, qualifications standards and registration requirements. See note 431 supra.

«s The exclusion in $\S 3$ (a) (18) does not carry over to $\S 3$ (a) (21).
} 
clearly included. Sections $15(\mathrm{~b})(8)$ and $15 \mathrm{~A}(\mathrm{~b})(5)$ are apparently broad enough to allow the Commission and the NASD to impose standards of character and integrity along the lines recommended by the Special Study.

In establishing these standards an association may distinguish between members on the basis of the type of business done and the nature of securities sold. For example, the legislative history contemplates that separate standards might be established for members limiting their activities to the sale of investment company shares. ${ }^{444}$ The Commission's statements and the Senate Report both "anticipate" that the NASD will adopt appropriate grandfather clauses exempting existing members or persons now associated with members from some or all of the qualifications required of new entrants. ${ }^{445}$ The House Report says the NASD "could" do that. ${ }^{446}$

An association is specifically authorized to require the registration of any class of natural associated persons, ${ }^{447}$ and to require pertinent information from associated persons and members. ${ }^{448}$ Any false or misleading statement in those applications will be subject to the criminal sanctions provided in section 32 (a).449

Under its powers in pre-existing sections, the NASD had used its registered representative program to impose registration and limited examination requirements on certain principals, salesmen, and supervisory employees. ${ }^{450}$ This new provision gives the NASD broad, ex-

\footnotetext{
" SENATE REPORT 82; House RePORT 26.

${ }^{2 \alpha}$ SENATE RePORT 82; House Hearings, pt. 1, at 229-30. The Scnate Report also indicated that securities associations should extend similar treatment to new members joining before July 1, 1964 (the effective date of required membership as it was then proposed) and persons associated with such new members on the date of their admission. Senate Report 82. The House Report contains a similar statement, still tied to the July 1, 1964 date, although the House Committee deleted required membership. House Rerort 26. Since the act was signed in August 1964, these statements seemingly have no effect. However, reasonable grandfather clauses or transition periods could be provided by the NASD for firms joining, for example, within the next 12 months, as $\S \S 15$ (b) (8)-(10) will probably cause some nonmember firms to join the NASD.

"HOUSE Rerort 26.

" Clause (F) of $\S 15 \mathrm{~A}(\mathrm{~b})(5)$ seems to refer to all associated persons. However, the limitation in the first part of the paragraph to "natural" associated persons may apply tluroughout. But see note 442 supra.

"s The House Committee made a technical change in clause (E) that appears to mean that an association may not require, in applications to become associated with 2 member, information concerning financial responsibility. But see note 442 supra.

* The committee reports appear to say that the sanctions are applicable to applications to become a member or to become associated with a member. SENATE REPORT 81; House Rerort 26. However, it is not altogether clear from clause (F) that the sanction applies to the former.

${ }^{40}$ See 2 Loss 1367-69; House Hearings, pt. 1, at 146-47.
} 
press powers in this area, and, perhaps even more importantly, requires it to raise its standards. Because of a 1942 Commission decision, the NASD has been considered to be without power to impose capital requirements, ${ }^{451}$ a problem remedied by this provision.

The Commission is given an important role in setting the standards. Association rules under section 15A (b) (5) are subject to Commission disapproval under section $15 \mathrm{~A}(\mathrm{j})$ and can be abrogated, altered, or supplemented by the Commission under sections $15 \mathrm{~A}(\mathrm{k})$ (1) and $15 \mathrm{~A}(\mathrm{k})(2)^{452}$ In addition, the Commission may, on a caseby-case basis, approve or direct an association waiver of its qualifcations rules under section $15 \mathrm{~A}(\mathrm{~b})(5)$.

\section{Association Disciplinary Rules}

The Amendments Act adds the requirement that association rules provide that persons associated with its members be appropriately disciplined for any violation of association rules. ${ }^{458}$ The discipline of associated persons can take the form of a fine, censure, suspension or barring from association with all members, or "any other fitting penalty." The similar pre-existing requirement of disciplinary rules for members is substantially unchanged. ${ }^{454}$

The NASD's rules presently provide for the disciplining of registered representatives for any violation of NASD rules, but only in connection with a proceeding against a member. This change will allow the NASD to amend its rules to provide that proceedings may, in the NASD's discretion, be directed solely against individuals without joining members. ${ }^{455}$

Arguably, the amendment requires the NASD to expand the reach of its disciplinary rules to cover a much broader range of associated persons. ${ }^{456}$ On the other hand, the very definition of "person associated with a member" might make it difficult for the NASD to discipline associated persons not registered with the association.

\footnotetext{
¿51 National Ass'n of Sec. Dealers, Inc., 12 S.E.C. 322 (1942).

152 Senate Report 82, 87; House Report 26.

${ }^{45}$ Securities Exchange Act of 1934, $\S 15 \mathrm{~A}(\mathrm{~b})(9)$, amended and renumbered by Pub. L. No. 467 (Sccurities Acts Amendments of 1964), 88th Cong., 2d Sess. $\S \S 7$ (a) (4) - (5) (Aug. 20, 1964).

\&s One addition is that a member may bc suspended or barred from being associated with all members, a sanction which apparently has no greater effect than suspension or expulsion from membership.

¿ss SENATE REPORT 82; House Hearings, pt. 1, at 230.

cso Ibid.
} 
In the absence of registration, if a disciplinary proceeding is instituted against an associated person, he might, by severing his relationship with the firm, escape NASD disciplinary action. ${ }^{457}$ This may be one good reason for the NASD to restrict its discipline of associated persons to those registered with the association, although registration might be required of wider classes of associated persons.

Section 15A has always required that in disciplinary proceedings against members, associations must extend specified due process protections. ${ }^{158}$ The Amendments Act requires, in conformance with the NASD's present practice, ${ }^{459}$ that such protections also be provided for associated persons who are parties to disciplinary proceedings. ${ }^{\mathbf{1 0 0}}$

\section{Procedural Safeguards on Denial of Association with a Member}

In any proceeding by a registered securities association to determine whether a broker-dealer will be denied membership, section 15A has always required that: (1) the association give the brokerdealer notice and an opportunity to be heard; (2) a record must be kept; and (3) the determination shall set forth the specific grounds upon which the denial is based. ${ }^{161}$ The NASD rules have provided these protections in denial of membership proceedings, ${ }^{\mathbf{1 6 2}}$ but have not done so where initial denial of registered representative status has been involved. The Amendments Act commands ${ }^{463}$ that these safeguards be provided where a registered securities association is considering denial of registered representative status or any initial

157 Under $\$ 3($ a) (21), the person would cease to be an associated person, and $\S 15 \mathrm{~A}(\mathrm{~b})(9)$ and other portions of $\S 15 \mathrm{~A}$ speak only of discipline of associated persons. The fact that $\S 3$ (a) (21) was purposely drafted to give associations a means (by registration) of retaining jurisdiction over persons who lave severed their relations with the firm may suggest that disciplinary proceedings must fall if the respondent ceases to be an associated person. On the other hand, the Commission's experience under prior $\S 15(\mathrm{~b})$ indicates that the NASD could at least proceed, make findings, and enter an order which would be binding in applying rules under $\$ \S 15 \mathrm{~A}$ (b) (3)-(5) if the person later applied for admission as a member or for registered representative status. See authorities cited note 376 supra.

${ }^{480}$ Securities Exchange Act of 1934, $\$ 15 \mathrm{~A}(\mathrm{~b})(10)$, amended and renumbered by Pub. L. No. 467, 88th Cong., 2d Sess. $\S \S 7$ (a) (4), (6) (Aug. 20, 1964).

${ }^{400}$ See 2 Loss 1368.

${ }^{400}$ See statute cited note 458 supra.

401 See statute cited note 458 supra.

${ }^{102}$ NASD By-laws, art. I, $\S 4$.

des See statute cited note 458 supra. 
barring of association with a member. Thus, the Act will require some changes in the NASD's rules. ${ }^{464}$

\section{N. Association Quotations Rules}

New section $15 \mathrm{~A}(\mathrm{~b})(12)$ requires association rules to include "provisions governing the form and content of quotations relating to securities sold [in the over-the-counter market] ${ }^{405}$... which may be disseminated by [members and associated persons] . . . and the persons to whom such quotations may be supplied." The second sentence of that section requires that those rules be designed "to produce fair and informative quotations, both at the wholesale and retail level, to prevent fictitious or misleading quotations, and to promote orderly procedures for collecting and publishing quotations." This provision authorizes and directs activities in an area in which the NASD has long been active. Some of its activities have been conducted without the benefit of formal rules, however, and the extent of association powers over quotations under prior section I5A was unclear.400

The statements of the NASD, the Commission and committee reports do not specifically discuss the effect of the new provision on the existing retail quotations activities of the NASD. These activities were sharply critized, however, by the Special Study, ${ }^{407}$ especially insofar as the NASD quotations supplied to newspapers and other periodicals (retail quotations) deviate from interdealer (wholesale) quotations.

Two obvious conclusions can be reached. First, a separate "retail" system of some kind is authorized, though probably not required. The reference to "both at the wholesale and retail level"

\footnotetext{
so6 Neither the Commission's statements nor the committee reports mention this change, but the changes in the statute are unmistakably clear. Opportunity for hearing undoubtedly is not required where, for example, a prospective salesman fails to pass the objective examination administered by the NASD. In addition, most of the grounds specified in the NASD's By-laws are such that an opportunity for hearing would probably seldom be required, since they are based upon orders or convictions entered by the Commission, the NASD, an exchange, or courts. Sec NASD By-laws, art. $I, \S 2$ (a), NASD Manual C-5; id., art. XV, § 3 (b), NASD Manual C.54.

405 The reference in the House Report to quotations for unlisted securities seems too narrow. House RePORT 2. The statute refers to quotations for securities "sold otherwise than on a national securities exchange." This appears to include quotations for listed securities traded in the over-the-counter market.

"Bo Senate Report 83; House Hearings, pt. 1, at 230-31; Special Study, pt. 2, at 595-609, 630-43.

${ }^{407}$ Special Study, pt. 2, ch. VII. See also Loomis \& Rotberg, Over-The-Gounter Market Quotations, 62 MicH. L. REv. 589 (1964).
} 
is best interpreted as stating that if separate retail and wholesale quotations systems exist, appropriate, formal rules under section 15A (b) (12) must apply to both. Secondly, the NASD's quotations must conform to the "fair and informative" and not "fictitious or misleading" standards of section $15 \mathrm{~A}$ (b) (12). In the House Hearings, the NASD said that one of the Special Study's recommendations in the quotations area "would destroy established merchandising concepts in the over-the-counter market and drastically affect the liquidity and depth of markets in many securities issues." 468 While such factors might be material in choosing between different systems that meet the standards of section $15 \mathrm{~A}$ (b) (12), they cannot be used to justify a system not meeting the standards of that section. The House Report clearly makes this point. ${ }^{469}$ Of course, this is primarily a truism that leaves unanswered the difficult question whether a given system qualifies under the section 15A (b) (12) tests.

An interesting question is raised by the requirement that the NASD's rules must be designed "to promote orderly procedures for collecting and publishing quotations." The word "publishing" appears to mean that at least certain quotations must be made available to the public. 470 The NASD's present retail quotations (which include an undisclosed markup from the wholesale quotations on the asked side) are now made available to the public through publication in newspapers and other periodicals. On the other hand the interdealer, or wholesale, asked quotations are generally available only to brokerdealers and their large clients. Does section $15 \mathrm{~A}$ (b) (12) require that the wholesale, as well as the retail, quotations be made available to the general public? The language of the section is not entirely

${ }^{108}$ House Hearings, pt. 1, at 627.

${ }^{100}$ See House REPORT 2, 8, 27.

${ }^{470}$ There are several reasons for this assertion: (1) On its face, the word appears to mean a making available to the public. (2) The first sentence of the section gives the NASD sweeping power to tell its members to whom quotations shall be given. [Undoubtedly, no one intended that the NASD be given the power to prevent firms from making quotations directly available to the general public without a correlative duty to require that some quotations be made available to the public. See, e.g., Securities Exchange Act of 1934, § 2 (2), 48 Stat. 882, 15 U.S.C. § 78b (2) (1958).] (3) The NASD occupies a position in the over-the-counter market analogous to that of the exchanges in the exchange markets, and exchanges make quotations public. (4) In certain portions of $\S 12$ (f) which were deleted by the Amendments Act, there were references to the publication of quotations, which references clearly meant making available for general publication. (5) An NASD statement submitted to the House Subcommittee seems to equate publication of wholesale markets with making quotations available to the general public. House Hearings, pt. 1, at 627 (item 9). 
clear on this point and the legislative history is silent. ${ }^{471}$ Any requirement that the NASD make both retail and wholesale quotations available to the general public would implement the Special Study's recommendations. The Special Study recommended that the NASD's retail quotations system be supplanted by a system of wholesale quotations. A requirement of publication of both types of quotations would not be entirely consistent with that recommendation, but it would give the public the information that the Special Study recommended should be made available. ${ }^{\text {t72 }}$

The NASD is currently discussing with the Commission plans to publish a form of wholesale bid and asked quotations on some 1,300 over-the-counter stocks. ${ }^{472 a}$

Although in fashioning its legislative program the Commission had considered a provision giving it direct regulatory powers over independent quotation bureaus, ${ }^{473}$ no such proposal was made to Congress. The Commission explained that the underlying Special Study chapter had not been published or made available to the securities industry and, therefore, that it seemed undesirable to submit the legislation until it had the opportunity to obtain industry views. ${ }^{474}$ Section 15A (b) (12) is not a substitute for direct Commission regulatory powers over independent quotation bureaus, although the powers given the NASD in that section, coupled with an exercise of somewhat similar Commission powers under section 15 (c) (2), may significantly minimize or even remove the need for those direct regulatory powers. For example, the NASD and the Commission could: (1) prevent dissemination of quotations through an independent bureau which does not properly try to prevent fictitious or misleading quotations, and (2) discipline broker-dealers which supply fictitious or misleading quotations to such a bureau.

${ }^{471}$ Most of the Commission's statements and the Senate Report state that the section is not intended to be a resolution of "the substantive problems with respect to quotations" discussed in Chapter VII of the Special Study. SENATE REPORT 83; House Hearings, pt. 1, at 230-31. On the other hand, another Commission statement furnished to the House Subcommittee implies that $\S 15 \mathrm{~A}(\mathrm{~b})(12)$ will aid in the implementation of the Special Study's Chapter VII recommendations. House Hearings, pt. 1, at 158. 172 The Special Study's recommendation is found in Special Study, pt. 2, at 677 (recommendation 9). If both wholesale and retail quotations were required to be made public, the retail system would probably be abandoned.

${ }_{4722}$ CCH FED. SEC. L. REP. If 77143. See also N.Y. Times, Oct. 21, 1961, p. 67, col. 8; id., Oct. 22, 1964, p. 49, cols. 6, 7; Wall Street Journal, Oct. 22, 1964, p. 3, col. 1 . ${ }^{473}$ House Hearings, pt. 1, at 6, 650, 655-56.

474109 CONG. REC. 9963, 9967-69 (1963). 
O. Effective Date of Amendments to Section 15A (b) and New Power to Suspend an Association's Registration

A new unnumbered paragraph added at the end of section 15A (b) provides that

The provisions of this subsection, as in effect prior to the date of enactment of the Securities Acts Amendments of 1964, shall be applicable to the rules of any registered securities association which was registered on such date until July 1, 1964. After July 1, 1964, the Commission may, after notice and opportunity for hearing, suspend the registration of any such association if it finds that the rules thereof do not conform to the requirements of this subsection, as amended by section 7 of the Securities Acts Amendments of 1964, and any such suspension shall remain in effect until the Commission issues an order determining that such rules have been modified to conform with such requirements.

One consequence of this provision is to provide a July 1,1964 , effective date for the changes in section 15A(b). When the Senate passed S. 1642 in July 1963, the July 1, 1964, date was a meaningful deferral, although since enactment came after that date, retroactivity was the final result. Moreover, the new suspension power clearly can be used if the NASD does not conform its rules to the changes made by the Amendments Act. The NASD should, and presumably will, be given a reasonable period of time in which to make the necessary changes, since conformance was obviously impossible by July 1, 1964.

The House Report appears to interpret the provision as having a third effect, by stating that the provision makes "it clear that the requirements as to the rules of the securities associations are continuing requirements which are applicable not only on the question of initial admission to registration of a securities association but must thereafter be complied with as well." 475 This implies that the new provision provides a continuing suspension power for use at any time the Commission may find that the association's rules do not conform with section $15 \mathrm{~A}(\mathrm{~b})$, and that its use is not limited to nonconformity with provisions added to section $15 \mathrm{~A}$ (b) by the Amendments Act. Such an interpretation is not at variance with the language of the provision. Indeed, it is not necessarily in conflict with the Senate Report and the Commission's statements, although they

\footnotetext{
${ }^{45}$ House RePORT 27.
} 
imply that the suspension power runs only to noncompliance with the changes made by the Amendments Act. ${ }^{470}$

The new paragraph assumes considerable significance if it does mean that the Commission has continuing suspension power. If the new paragraph is so interpreted, the Commission could apparently institute a suspension proceeding when an association refuses to adopt any new substantive rule recommended by the Commission, and suspend if it finds that the association's rules do not conform to section $15 \mathrm{~A}(\mathrm{~b})$ without the addition of the recommended rule. ${ }^{477}$ Under prior law it had been assumed that once an association's registration is approved, the Commission's controls over association rules were limited to a veto power over proposed new rules, ${ }^{478}$ a power to abrogate existing rules, ${ }^{479}$ and the power in section $15 \mathrm{~A}(\mathrm{k})(2)$ to alter or supplement association rules in four limited areas. The last-named power relates to the rules concerning the organization and operation of the association rather than to the association's rules governing substantive conduct of its members. The sole pre-existing express suspension powers, which are contained in unchanged section $15 \mathrm{~A}(l)(1)$, may be used only if the association violates the Exchange Act or rules thereunder, fails to enforce compliance with its own rules, or has engaged in any activity tending to defeat the purposes of section $15 \mathrm{~A}$. None of these appears to deal with the situation where, by inaction, the association's rules have become inadequate.

Of course, suspension of registration of an association is heavy artillery, especially when such action would seemingly subject all of the association's members to new sections 15 (b) (8)-(10). In light of this and the Commission's feeling that the NASD has always reacted responsibly when the Commission has suggested the adoption of new rules, the new suspension power-whatever its scope-will undoubtedly be used with great restraint. ${ }^{480}$

\footnotetext{
${ }^{480}$ See Senate Report 84; House Hearings, pt. 1, at 231.

477 Under $\S 15 \mathrm{~A}(\mathrm{e})$ the Commission is to grant registration only if the association's rules meet the requirements of $\S 15 \mathrm{~A}$. However, an association's rules, though adequate on the date of initial registration, might become inadequate over a period of ycars. ${ }^{478}$ Securities Exchange Act of $1934, \S 15 \mathrm{~A}(\mathrm{j})$, added by 52 Stat. 1074 (1938), 15 U.S.C. $\$ 780-3(\mathrm{j})(1958)$.

470 Securities Exchange Act of 1934, $§ 15 \mathrm{~A}(\mathrm{k})(1)$, added by 52 Stat. 1074 (1938), 15 U.S.C. $\$ 780-3(k)(1)(1958)$.

480 House Hearings, pt. 1, at 39,655 (Commission's statements on reaction of NASD). This kind of a power is even more abrasive and far-reaching than the power to alter or supplement rules. In this connection the Commission considered, and decided against, recommending a basic extension of its powers to alter or supplement under $\S 15 \mathrm{~A}(\mathrm{k})(2)$. In the Exchange Act portion of its 1959 legislative program, the Com-
} 


\section{P. Commission Review of Association Action against Firms and Associated Persons}

In sections $15 \mathrm{~A}(\mathrm{~g})$ and $15 \mathrm{~A}(\mathrm{~h})$, the Maloney Act provided the Commission with extensive powers and responsibilities for review of association action against members and broker-dealers whose applications for membership are rejected. The Amendments Act ${ }^{481}$ expressly provides that the same review powers are applicable to association action in disciplining associated persons and initial barring of association with a member. This is primarily a codification of the existing practice. For example, since the NASD has proceeded against associated persons in disciplinary actions only as a part of a proceeding against a member, the Commission has reviewed NASD discipline of associated persons in the same manner as discipline of members. The change will, however, enable the Commission to review association discipline of associated persons where the association proceeds, as authorized by the Amendments Act, solely against associated persons. It is not clear what effect the change will have upon Commission review of NASD action refusing to allow a person to become associated with a member. The Commission has effectively reviewed such action in the past by passing on the firm's eligibility to continue in membership, ${ }^{482}$ but the Amendments Act probably gives prospective associated persons the standing, in some situations, to seek Commission review in their own name. ${ }^{183}$

mission recommended, notwithstanding its $\S 19$ (b) powers, an amendment of $\S 19$ (a) (1) to allow it to suspend or withdraw the registration of a national securities exchange if it found that the exchange has ceased to meet the requirements for original registration specified in $\S 6$. The Exchange Act portion of that program was not enacted. For a discussion of the program, see 1 Loss 205 n.80. The NASD opposed the amendment to $\$ 19$ (a) (1). See Hearings on S. 1178-82 Before a Subcommittee of the Senate Committee on Banking and Currency, 86th Cong., 1st Sess. 78 (1959).

${ }^{481}$ Securities Acts Amendments of 1964, $\S \S 7$ (c)-(d), Pub. L. No. 467, 88th Cong., 2d Sess. (Aug. 20, 1964).

482 See 2 Loss 1367-68, 1386-87.

${ }^{483}$ This would especially seem to be the case where there has been a formal proceeding at the NASD level, since review under $\$ \S 15 \mathrm{~A}(\mathrm{~g})-(\mathrm{h})$ as amended would fit squarely into the pattern. See note 464 supra and accompanying text. Where, however, the prospective associated person labors under a disqualification specified in a rule under $\S \S 15 \mathrm{~A}$ (b) (3)- (4) and a waiver is desired, the Commission's powers to approve or direct a waiver still appear to apply only at the firm's level. In those cases the request seemingly will still be made in the name of the firm under Rule 15ab-1, which governs the procedure relating to such requests. Under new $\S 15 \mathrm{~A}(\mathrm{~b})(5)$ the Commission's powers to approve or direct a waiver seem to apply both at the firm and individual levels. It would appear consistent with the spirit of the various amendments to $\S \S$ $15(\mathrm{~b})$ and $15 \mathrm{~A}$, which placed more emphasis on the individual as a regulatory unit, to allow requests for waivers in the individual's name. A request by an individual for a 
Another change in this area concerns the effect of the institution of Commission review upon association action. Before the Amendments Act the institution of Commission review always resulted in a stay of association action until final Commission disposition. The Amendments $\mathrm{Act}^{484}$ authorizes the Commission, after notice and opportunity for hearing on the question, to lift a stay. A hearing on lifting of the stay may, in the Commission's discretion, ${ }^{485}$ consist solely of affidavits and oral arguments. The legislative history indicates that this new power should be used sparingly, but that its use would be proper where an appeal is clearly taken for dilatory purposes and injury to the public should be prevented pending final Commission determination. ${ }^{486}$ Presumably, a hearing on lifting of the stay would be held only where suspension or expulsion from membership, or suspension or withdrawal of registered representative status, is involved. Where lesser penalties are imposed, the firm or the associated person will, regardless of the final Commission decision, be allowed to continue in the association. In such cases there would seem to be no occasion for the time and effort required to hold a separate proceeding solely on the stay question. ${ }^{487}$

If the Commission adopts rules under section 15 (b) (8) specifying as one of its qualifications standards that a nonmember and his associated persons must not possess any of the disqualifications set forth in sections 15A (b) (3) and 15A (b) (4), Commission action in lifting a stay of NASD action which suspends or expels a firm from

waiver under the Commission's $\S 15 \mathrm{~A}(\mathrm{~b})(5)$ authority should seemingly be handled in substantially the same manner that a firm's request under Rule 15ab-1 is handled. Sce also SEC Sccurities Exch. Act Release No. 7408, Scpt. I, 1964 (amending Rules 15ab-1 and $15 \mathrm{ag}-1$ ). In these amcndments, no provision was made for direct revicw of NASD action in denying association with a member.

484 Securities Exchange Act of 1934, § $15 \mathrm{~A}(\mathrm{~g})$, amended by Pub. L. No. 467 (Securities Acts Amendments of 1964), 88th Cong., 2d Sess. $§ 7$ (c) (Aug. 20, 1964).

485 SENATE REPORT 85; House REPORT 28.

${ }^{480}$ See SENATE RePort 47; House Hearings, pt. 1, at 131. The section itself does not expressly contain a standard. Another portion of the Senate Report states that the stay could be lifted only if the Commission "found it to be necessary or appropriate in the public interest or for the protection of investors so to ordcr." SENATE REPORT 85. The House Report makes no mention of the standard under which action is to be taken. See House Report 28.

487 Even in the case of a suspension (as opposed to expulsion), there arguably might be no occasion for the time and effort required to hold a separate proceeding. See also authorities cited note 486 supra and accompanying text. Where a sanction less than expulsion or removal of registered reprcsentative status is involved, presum. ably the association has determined that the violation is not serious enough to warrant a permanent exclusion, and it would be difficult to argue that immediate imposition of the sanction is necessary to prevent injury to the public. 
membership, or removes registered representative status, would bar the firm or the person from conducting almost all types of overthe-counter securities business. ${ }^{488}$ If, on the other hand, such qualifications standards are not adopted under section 15 (b) (8), the lifting of the stay in such a case would affect only NASD membership or association with NASD members, and the member or person could continue in the business. ${ }^{489}$

The Commission may order a hearing on the question of a stay either on its own motion or on application of the association, and action upon such application for a hearing may be taken summarily and without notice by the Commission. ${ }^{490}$ A refusal by the Commission to order a hearing on the question (or, after opportunity for hearing, to lift the stay) would not be appealable by the association. ${ }^{491}$ Nothing is said about the appeal of a Commission order lifting the stay. ${ }^{\mathbf{4 9 2}}$

The last change in this area shortens the period in which a person aggrieved by association action must petition the Commission for review from "sixty days ... or such longer period as the Commission may determine" to "thirty days . . . or such longer period as the Commission may determine." 493

\footnotetext{
${ }^{68}$ As a technical matter, registration under $\S 15$ (b) would not automatically be revoked or suspended; because of the language of $\S 15(\mathrm{~b})(8)$, however, the firm could not execute over-the-counter securities transactions so long as the suspension or expulsion remained in effect, although it could continue to do business on a national securities exchange. If allowed to terminate its registration, it could conduct either of the two types of over-the-counter business for which $\$ 15$ (a) does not require registration; in the alternative, it could conduct an exchange business. Where removal of a registered representative's status is involved, his continued association with the firm would have the same effect on the firm and thus only an unregistered firm could, without Commission consent, safely allow him to be associated.

${ }^{68}$ Such a member could continue to do any type of over-the-counter securities business, although without the advantage provided by the NASD's economic inducement rules, and association with a registered nonmember firm would not preclude it from continuing to do business.

${ }^{100}$ SENATE REPORT 85; House Hearings, pt. 1, at 232.

101 Ibid.

102 Ibid. In the Senate committee report issued on the Exchange Act portion of the Commission's 1959 legislative program, it is stated that a Commission order which is issued under $\S 15$ (b) which postpones registration until final determination on denial is appealable. S. ReP. No. 1757, 86th Cong., 2d Sess, 6 (1960). The Exchange Act portion of that program was not enacted. For a discussion of that program, see I Loss 205 n. 80.

${ }^{103}$ This is accomplished by an amendment to $\$ 15 \mathrm{~A}(\mathrm{~g})$. As a result of this change the Commission has shortened the period specified in its Rule I5ag-1 from 60 to 30 days. SEC Securities Exch. Act Release No. 7408, Sept. 1, 1964.
} 
Q. Commission Power to Alter or Supplement Rules

Section 15A (k) (2) is expanded by the Amendments Act to empower the Commission to alter or supplement association rules in two additional areas: (l) the basis and procedure for barring persons from association with a member or the disciplining of persons associated with members; and (2) the qualifications required for members or natural ${ }^{494}$ persons associated with members. Consistent with the philosophy of the Maloney Act, ${ }^{405}$ this expansion concerns only rules relating to the organization and operation of the association as such and does not relate to substantive rules governing the business conduct of members. The Commission's April 19, 1963, draft would have allowed it to alter or supplement association rules in all substantive areas.996 This proposal was dropped before the bills were submitted to Congress. The Commission explained that many of its own rulemaking powers had never been fully exercised, and that until these powers were exercised and found deficient, no change would be requested. In addition, the Commission noted that needed improvements have always been secured after conferences and discussion with the NASD. ${ }^{407}$

One procedural change is made in section $15 \mathrm{~A}(\mathrm{k})(2)$. Once the Commission proposes an alteration or supplement, it is expressly authorized to modify the alteration or supplement before adoption thereof is ordered. Under prior law it was not clear whether there could be a modification. ${ }^{488}$ The prior requirements of notice and opportunity for hearing and of giving the association a reasonable time in which to adopt the alteration or supplement are unchanged.

R. Change in Section 15A (d)

The cross references in section 15A (d) were revised to conform to the changes in section $15 \mathrm{~A}(\mathrm{~b})$.

IV

\section{Commission REPORTINg ObLigation}

At the same time that Congress imposed new obligations upon

to Explained in House Hearings, pt. 1, at 233 n.8. See also SENATE REPORT 56.

495 See Special Study, pt. 4, at 716-17; Hearings on S.3255 Before the Senate Committee on Banking and Currency, 75th Cong., 3d Sess. 24-26 (1938); S. REP. No. 1455, 75th Cong., 3d Sess. 9 (1938).

${ }^{108}$ House Hearings, pt. 1, at $32,667$.

${ }^{407} I d$. at $39,655$.

${ }^{109}$ Cf. Loomis, The Securities Exchange Act of 1934 and the Investment Advisers Act of 1940, 28 GEO. WASH. L. REv. 214, 222-24 (1959) (discussion of analogous provisions of $\$ 19(\mathrm{~b}))$. 
thousands of persons, it also imposed one on the Commission. The House Committee added an amendment to section 23 (b) decreeing that the "Commission shall include in its annual reports to the Congress for the fiscal years ended on June 30 of 1965, 1966, and 1967 information, data, and recommendations specifically related to the operation of the amendments to [the Exchange Act] . . made by the [Amendments Act] . . . " This is a manifestation of the continuing interest of Congress in the Special Study and the regulation of the securities markets-an interest also evidenced by the comprehensive hearings and scrutiny Congress gave to the Amendments Act and by the ingenious (and probably effective) compromises made with regard to required membership in a registered securities association and coverage of banks and insurance companies. 